Dedicated to the memory of those who went before and taught us to see in different ways; Eli Mandel, Earle Birney, Aleksandrs Pelecis and the others, remembered, from time to time. 1995.

\section{*** *** ***}

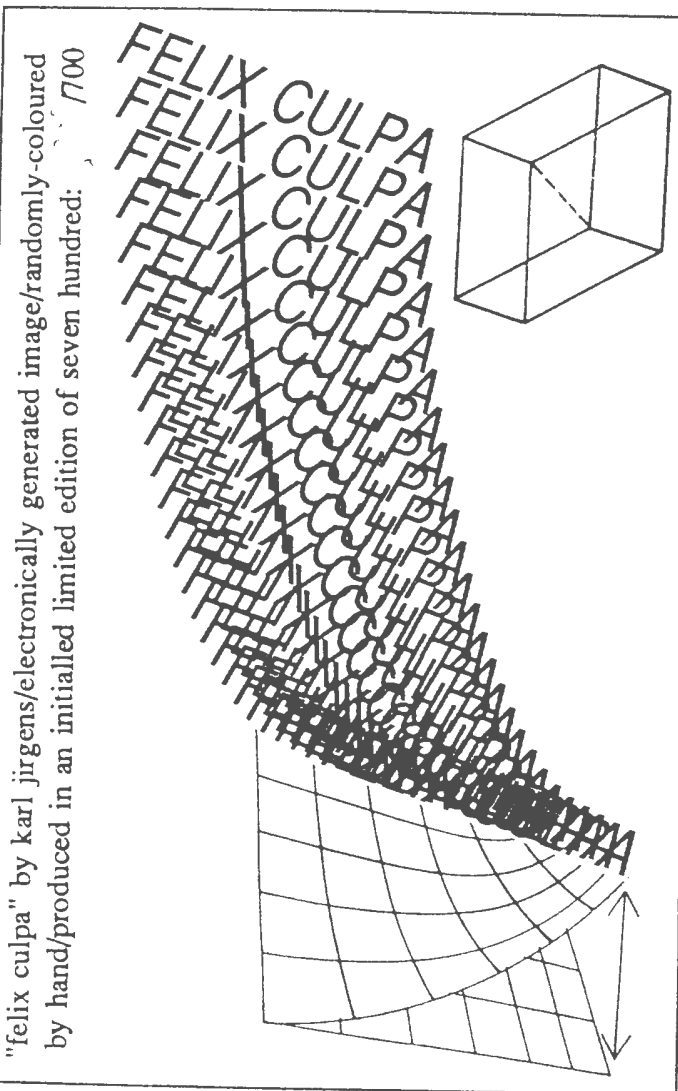

Finally, here is the special issue on Creative Misunderstanding

Rampike will continue to appear sporadically in future. However, this marks the end of an era of government assisted publishing. We have cut ourselves loose and now answer only to ourselves, our sense of adventure and to you, our readers. And so it is possible/possible, in the spirit of Creative

Misunderstanding to begin this issue by concluding that our terminus marks a new beginning. Heartfelt thanks to all those who helped this magazine over its fifteen year course. Thanks for your loyalty and patience over the years!

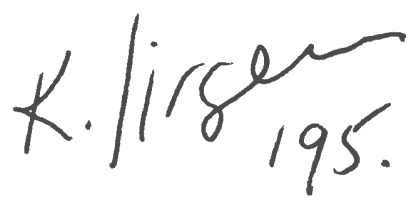

INDEX

Pierre-André Arcand

\& Karl Jirgens p. 2 Julia Kristeva p. 4

Guillermo Deisler p. 7

Steve McCaffery p. 8 Frank Davey p. 9 Kirby Olson p. 10

Tomson Highway p. 12 Rolland Nadjiwon p. 14 Howard Webkamigad p. 15 M. Vanci Stirneman p. 15 Christopher Dewdney/

Interv. Karl Jirgens p. 16 Karl Jirgens p. 21 Dick Higgins p. 26

Skogebär Bergbo p. 26 Bengt af Klintberg p. 27 Jackson MacLow p. 27 Alison Knowles p. 28 John Cage p. 28 Miekal And p. 28 Miekal And p. 28
Charles Doria p. 29 Giulia Niccolai p. 29 Liz Was p. 29

Steve McCaffery p. 30 Richard Kostelanetz p. 31 Juan Opitzl

Interv. Rosemary Sullivan p. 32

Clarice Lispector/

Trans. Alexis Levitin p. 37 Saúl Yurkievich/

Trans. Cola Franzen p. 39 Ray Sousterl

Interv. Carole A. Turner p. 40 Andra Nieburgal

Trans. Banuta Rubess p. 44 Gvido Kajons \& Valts Kleins p. 45 Aleksandrs Pelecis/

Trans. Karl Jirgens p. 50 Opal Louis Nations p. 52 Devon Eastland p. 52 Robert Anderson p. 53 Chris Belsito p. 54

Fernando Aguiar p. 55 Helen Lovekin p. 56 Chris Belsito p. 57 Barry Butson p. 57

John M. Bennett p. 57 Joan Chevalier p. 58 Jurgen 0 . Olbrich p. 59 Joanna Gunderson p. 60 Gil Adamson p. 61 Kevin Conolly p. 62 Alice Burdick p. 62 Kim Ackerman p. 63 Adeena Karasick p. 63 Lynn Crosbie p. 64 Jim Francis p. 65 Brigitta Bali p. 66

Natasha Kzonzek p. 66 Mark Shadle p. 67 Dong Jiping p. 67 D.S. Black p. 68 Nirmal Dass p. 68 Richard Truhlar p. 69 Clint Burnham p. 70 Justice Howard p. 70 André Duhaime p. 71 bill bissett p. 72 bill keith p. 72 Michael Winkler p. 73 Gabor Gyukics p. 74 Karen Clint p. 74 John Barlow p. 75

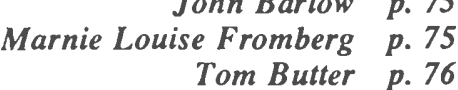
Roland Sabatier p. 76 Andrzej Dudek-Dürer p. 77 Paul Dutton p. 78 Helen Lovekin p. 78 Alain-Arthur Painchaud p. 79 Denis Boucher p. 79 Books Received p. 80 


\section{Bi-Lingual Interview avec/with MISS UNDERSTANDING par/by}

\section{Pierre-André Arcand \& Karl-Eduard Jirgens}

P.A.: J'ai beaucoup de questions. Et la première porte sur la traduction. Il est possible de penser en français ce concept de "creative misunderstanding" dont vous êtes la personnification, il est possible donc de le traduire par au moins trois équivalents: mésintelligence créatrice, malentendu créateur, méconnaissance créatrice. On pense à la méconnaissance créatrice des codes, à la mésintelligence créatrice du programme biologique ("reproduction is a creative misunderstanding of human sexuality"), au dysfonctionnement créateur des machines. Mais puisque la mésintelligence créatrice ne peut se définir que par rapport à une intelligence de référence, comment s'établit cette référence?

M.U.: Par consensus ou par fiction prédominante. Dans certains cas, la MC peut avoir une portée universelle, dans d'autres, elle nécessite la connaissance d'un contexte spécifique, une culture, une histoire, mais l'intelligence de référence est justement ce que l'on ignore ou que l'on choisit d'ignorer. Par exemple, y a-t-il eu thérie plus sujette à la mésintelligence créatrice que la théorie de la relativité? $\mathrm{E}=\mathrm{MC}^{2}$ est la formule même de la $\mathrm{MC}$ au carré.

P.A.: I guess the history of philosophy, poetry mostly and science is full of creative misunderstandings frequently revealing or expanding the principles of creative misunderstanding. Do you have any favourite exponents of creative misunderstanding in the field of artistic expression?

M.U.: I believe that John Cage offers an intriguing example. He combines poetry, music, art, chance and philosophy: his "misreadings," his creative misunderstanding of science and his (mis-)use of the I-Ching, and so on, generate aleatory and unpredictable processes typical of CM.

P.A.: La MC serait donc une heuristique, mais pourquoi serait-elle réservée aux artistes chercheurs ou expérimentateurs? Ne serait-elle pas active dans d'autres états ou d'autres formes d'art?

M.U.: C'est juste. Jusqu'à la crise du langage et de la représentation, il nous faillait considérer d'une part le monde extérieur, le réel dit objectif, et d'autre part le monde intérieur, imagination intellection, en allant de l'un à l'autre. Le langage, l'art étaient des ponts. Ce rapport est une $\mathrm{MC}$ et longtemps même après sa déconstruction (le "Ceci n'est pas une pipe" de Magritte, par exemple) il aura produit ses oeuvres.

K.J.: How would you represent yourself, Miss Understanding?

M.U.: With all due humbleness, if I may be permitted to give myself the title "creative", then a "Creative Miss Understanding" simply leads to a (re-)definition, whereby one is lead to an understanding of some one or some thing else. I can't translate here because we would lose the allusion, but I am gesturing to the small press and its founder, as well as to the "Institute for Creative Misunderstanding" in its broadest sense. Mais l'idee que ne pas comprendre conduit à comprendre autre chose est importante tant est puissant le besoin de comprendre. On trouve déjà chez Montaigne cette phrase: "Je tenu pour acquis l'idée que mal comprendre sait comprendre autre chose."

K.J.: If I may continue with the allusionary approach, what is the general idea involved with the "Institute for Creative Misunderstanding"? Why not, a "Pavilion of Creative Misunderstanding" or an "Academy," a "Lodge," or a "Circus?"

M.U.: The "Institute" is a fiction, it rests within a conceptual topography, a matrix of creative misunderstandings throughout the world, perhaps the universe. "Creative Misunderstanding" might even be understood as a fundamental universal axiom, something innate to all of existence, even if I do say so myself. As one who (mis-) represents CM. I can say without hesitation that true creative misunderstandings are often smothered inside of academies before they have a chance to expand to their full potential as grand theories of the preposterous. This was not always so, of course. You may recall that it was not long ago that scientists and the church alike alike maintained a geocentric view of the solar system, for example. But then Galileo and Copernicus went and ruined it all by arguing for a helio-centric view, which I found far less interesting. And nowadays of course, things are even more difficult. Since Einstein, the whole idea of centrism has been brought into question: "There is no centre in an infinite set," and all of that nonsense. I really have had to be on my toes lately to maintain my influence, not to mention my dignity. But, you can still see my influence in the language of the common day, "Stop and go traffic" for example, beautiful nonsense! Everyone knows it is "go and stop traffic -you have to go before you can stop!" "Four corners of the world," or, "People who skate on thin ice may find themselves in hot water!" Puns, mixed-metaphors, oxymorons, contradictions, paradoxes, misperceptions, slips-of-the-tongue, logical infelicities -- such are my small day-to-day joys. But these are mere crumbs, tell-tale signs of my influence. Many of the grand theories are disappearing. Still, I have my allies. The arts and sciences have much to offer in my name, "cold fusion" for example, then there is the internet (a wonderful source of confusion), and, of course, there are still the old standards such as politics, economics, religion, philosophy, zen and sexuality, not to mention psychology. You know, I find Lacan almost as remarkable as, say, Lewis Carroll, but he is more difficult to understand. There is a difference of course, between "creative" and "decreative" misunderstanding. I would add that I am not really interested in matters of war and so on, which I find to be tedious and quite counter-productive. Dreams are more to my taste and I truly adored the dark ages. There was so much potential then. I do enjoy mathematical theories on infinite sets, they seem so open to interpretation. Nowadays, I still have considerable powers, but I do feel that my influence is waning somewhat as we approach the twenty-first century. It isn't easy to be misunderstood all the time you know. But I'll stop here, because I don't want you to think that I am complaining. You might misunderstand, and all I am really doing is simply clarifying my position.

K.J.: If somebody pointed out that you misunderstood something or someone, how would you react; how would you respond?

M.U.: I would say that, by definition, any misunderstanding is a creative one, and so I wouldn't bother with such petty criticisms. You see, any misunderstanding, particularly a "creative misunderstanding" can serve to bring the topic to a new field of discussion. Therefore, every position can be thought of as a re-position or even a re-possession of an idea. Others might be less open-minded. But, so long as people take themselves as seriously as they currently do, I will remain in business.

P.A.: Pourtant, se méprendre, mal interpréter, mal comprendre, ça représente des coûts pour la pscyhè, le rapport à l'autre, le crédibilité ou même la solvabilité?

M.U.: Plutôt que de parler de coûts, si on doit conserver le point de vue économique, on parlera d'investissement. On ne peut pas revenir là-dessus. The misunderstanding of human beings, for example, has to be creative, or it is not worthwhile. Do you know of anybody who truly understands some one or thing?

P.A.: Oui. Yes, I believe I do.

M.U.: I might debate your belief, but let me be gracious -- I accept your position, for the time being... now tell me, is it not so, that if someone so much as believes that they understand another person, then they grow less interested in that other person? You know the old saying, "familiarity breeds contempt." Ne dit-on pas: ce que vous comprenez de l'autre n'est jamais l'autre tel qu'il se comprend. In many ways, I am indispensible, am I not?

P.A.: Ah, oui! Est-ce que vous avez conscience d'être asservie à un concept général qui cherche à polariser toutes les forces, toutes les explications en rapport avec la création? M.U.: Well, you know, we find many of the same event-phenomena in the dematerialized world. Those beings, those creative creatures of the human brain, don't really care about ruling thought or memory, as long as their incidental existence can enable one to be creative. There are different levels of satisfaction in the process of misunderstanding something, and for a lot of domains, the question will never be: "do I understand?" K.J.: What could the question be then?

M.U.: Well, the question "do I understand" presumes that things can be explained. Well, perhaps they can, to some degree, and then only from the limited point of view of the human mind. But, I might suggest that an alternate question might be: "what is the question?" or better yet, "is there a question?" I have been called "a very epistemological gal," but I question even that.

P.A.: Est-ce que je comprends bien... si je comprends mal? Si on réfléchit sur le phénomène de la compréhension, il y a une question contextuelle qui émerge ici: "what would be a creative misunderstanding of the creative misunderstanding phenomenon?" M.U.: Good question! I suppose in some ways you are asking "does such a thing as "creative misunderstanding' exist?" Well, yes and no. No, because CM is inevitably an extension of some other question. Creative misunderstanding cannot exist in a vacuum. On the other hand it could be said that $\mathrm{CM}$ does exist, so long as anything else exists because "creative misunderstanding" relies on a matrix of shifting meanings, the slide or "glissement" of the Signifier over the signified and all of that lovely linguistic nonsense. Or, it could be said that CM manifests itself through a resonant mosaic of alternating figure/ground relationships, as my old friend Marshall* was fond of putting it.

K.J.: Yes, that answers the matter of a creative misunderstanding of the creative misunderstanding phenomena, but what if we were to get more specific -- could you give us an example of a creative misunderstanding of a creative misunderstanding?

M.U.: Hmmm, another good question! I have always enjoyed the conceptual ourobouro configuration. Did I ever tell you that I introduced Moritz** to the idea? We were discussing Zeno, one day, and I showed him a picture of a snake biting its own tail. He was quite excited by the whole idea. But there I go digressing again. I will answer by saying that whenever people ask me that question, I prefer to respond with the following: "...the more you understand, the more you misunderstand, and the more you misunderstand, the more you understand..."

P.A.: Then what happens if you find that a simple misunderstanding is not creative? M.U.: Sadly, art critics, who often have the greatest potential for creative misunderstand, seem to prefer this uncreative position. Frankly, I am baffled. Critics often find creative misunderstandings in artistic expressions, but they seem to miss the point! Here is an example from Mediamatic magazine, an article about a video-art piece: "The misunderstanding is ultimately that no fundamental distinction is made between presenting work on TV or in the museum. The problem: aura versus wholesale reproduction." I am familiar with the artist that this critic refers to, and the point of installation was that no distinction was made between TV and Museum! Yet, the critic seems to take offense at this. A misunderstanding it seems. But is it creative? If you read further, you find the critic talking about exclusive categories: TV vs Museum, and Art vs Mass Production and so on, saying that if you put the two contexts together, you will get hybrid products. Hybrids are precisely the point. But again, the critic seems to consider this hybridization as some sort of flaw. A not very creative misunderstanding if you ask me.

P.A.: So, a hybrid product could be a "creative misunderstanding." Along the same lines, then, is appropriation a kind of "creative misunderstanding?"

M.U. Yes, basically, you cut something out from somewhere else, take it out of a context and don't take into account the origin, the intention, the totality. As a result, through recontextualization your transform the thing. Marcel ${ }^{* * *}$ knew about this. The sign and the intervention will generate a new meaning in the new context.

P.A.: Finalement, on peut dire que la MC est une définition de l'art, une esthétique, une éthique même.

M.U.: Assurément, mais elle tient à l'anonymat, à l'invisibilité, à la non conscience. Une MC, il n'est pas nécessaire de l'identifier comme telle pour qu'elle agisse. Elle ne passe pas obligatoirement par le langage.

P.A.: Thanks! Merci!

M.U.: MU! ****

* [Marshall McLuhan, editor's note, KJ].

** [M.C. Escher, editor's note, $K J]$.

*** [Marcel Duchamp. The interviewers were uncertain as to Miss Understanding's interest for people and events that begin with the letter " $M$ " however, we suspect there is some thing more to this than meets the eye, editor's note, KJ].

${ }^{* * * *}\left[" M u^{\prime \prime}\right.$ from a famous Zen koan. At this point. Miss Understanding made an ambiguous and possibly obscene gesture with her left hand, stood up and walked away, editor's note, KJJ. 


\section{SAMURAI/SEMIOTIQUE: AN INTERVIEW WITH JULIA KRISTEVA \\ by Karl Jirgens}

Julia Kristeva is a renowned linguist, teacher, writer and practising psychologist currently working in Paris. Her breakthrough studies on semantics were first presented in Semeiotiké: Recherches pour une sémanalysis (Semiotics: studies towards a semanalysis, Paris, 1969). Kristeva has been analyzed the production of meaning and the role of the human subject in language as well as the social-subjective function of language. Her analysis of literature has applied post-Lacanian and post-structural methods towards a feminist exploration of speech, the maternal body and pre-oedipal sexuality (see: Polylogue Paris: 1977, \& Desire in Language, N.Y.: 1980). Along with other "samurai" such as Barthes, Althusser, Derrida, Foucault and Lacan, Kristeva has become a major figure in French theory and literature. Since 1970, along with Jacqueline Risset and Philippe Sollers, she has served on the editorial board of the avant-garde journal Tel Quel. Julia Kristeva is currently Professor of Linguistics at the Université de Paris VII, and a Professor of Literature at Columbia University. In the autumn of 1992 she was the Northrop Frye Visiting Professor, at the University of Toronto. Some of her books include Desire in Language: A Semiotic Approach to Literature and Art, Tales of Love, Revolution in Poetic Language, Powers of Horror: An Essay on Abjection, Black Sun: Depression and Melancholia, Strangers to Ourselves and Nations Without Nationalism. Her novel Samouraïs (Librarie Arthème Fayard, 1990) was translated into English by Barbara Bray under the title The Samurai (1992), and was released by Columbia University Press. Here she talks to Karl Jirgens about philosophy language and some of the characters in her book including Olga and Hervé who represent a social aspect, Martin and Carole who display sexual behaviour, as well as Joelle and Oren who feature a stoic psychological posture. The editors a Rampike are grateful to Julia Kristeva for graciously agreeing to this interview and are pleased to present it in its entirety [Ed. KJ].

$$
\text { *** ***** } \quad \text { *** }
$$

KJ: I've been looking at The Samurai and I've been wondering about how much of yourself you have represented in the book.

JK: Yes, there is something in The Samurai which is a reality for me. Olga was a girl who wanted to study English and because her parents were not communist, she was no allowed in the English school, so, this was also my case, and all my life I have had regrets about not knowing English as well as I would like to know it. When I began to write novels, I was not aware of why I was doing this [writing]. It was just a new experience in a very absolute way, I found I could not survive without doing it.

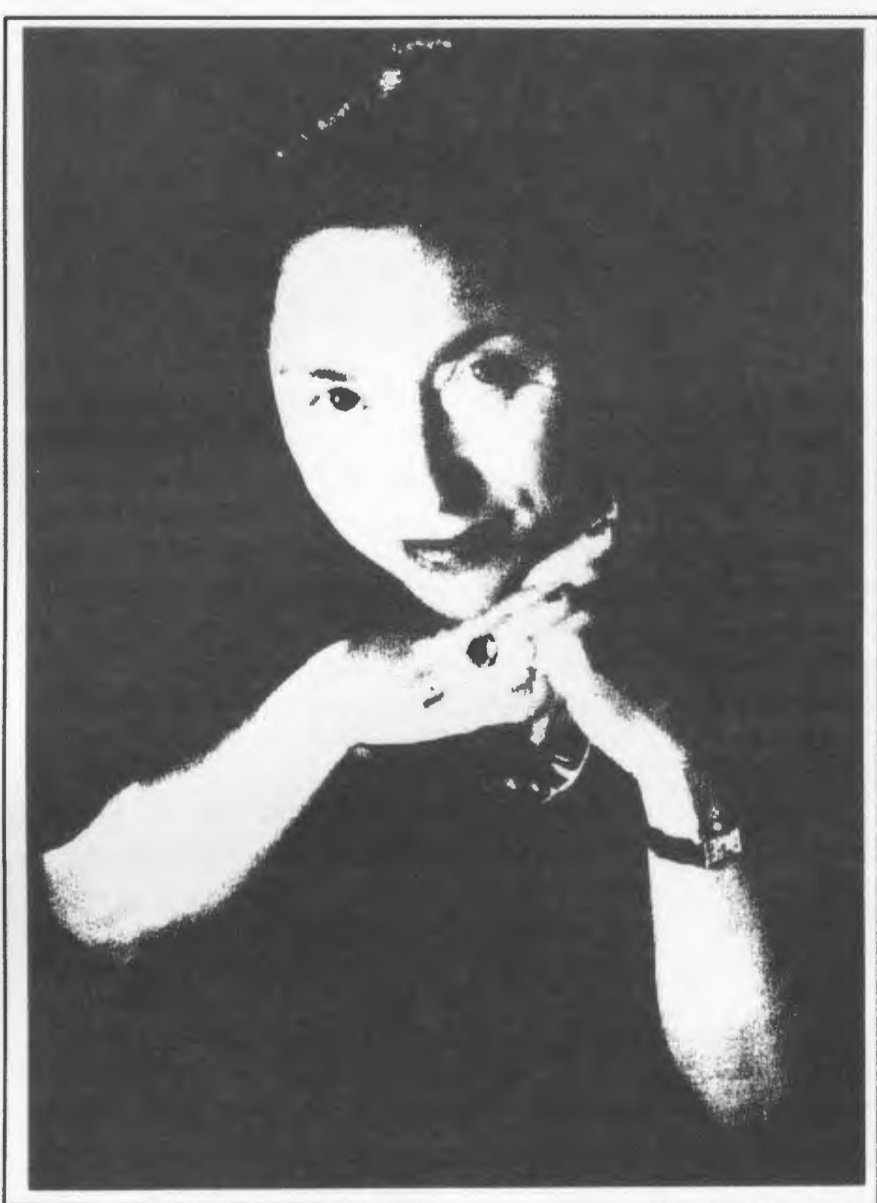

KJ: There are a number of characters in this novel that are based, at least partly, on actual figures such as Althusser, Barthes, Foucault, Lacan, Derrida, and others including yourself and we can think of these as prototypes. These figures can be thought of as "samurais" or "warriors" of language for whom writing is the only lasting act of pleasure and war combined [see: p. 42 43 -- Ed.]. In martial arts circles it is said that one's greatest opponent is one's self. Is this novel then a kind of aggression directed at yourself as other? For example, is the character Olga an alter-ego or "Other" in her guise as the traveller?

JK: The martial arts and the Samurai are used in different ways in this book. It is an allusion to the eastern culture. I am convinced that it is only through a dialogue with other cultures that French culture and western culture can be re-vitalized. So, I'm very interested in Chinese and Japanese, and I studied Chinese, I got a license [diploma] in Chinese, and I was very interested in how the mentality is modelled through another language, particularly Eastern languages that have evolved a lot of writing which arises out of very particular experience, along with gestural, pictorial, aesthetic and also a sort of mental discipline. But also martial arts are a metaphor for a race against death and towards death which this generation of Samurai experience, because in my mind, those men and those women in the structuralist and post-structuralist generation are quite different if you compare them to the Mandarins of Simone de Beauvoir. The Mandarins, were a people of power and authority, and they were risky, adventurers. But the Samurai were more than the Mandarins, they were really without any aspiration to be masters. And what you say is very true, we are, they are (those that are still alive), in a struggle with ourselves, in order to bypass our limits and to journey as Céline [Louis-Ferdinand] says, "to the end of the night", which is within ourselves.

Also, there is one experience that I tell about through the character of Olga, she is playing tennis, and it is based on something that happened to me, I like to play tennis but I'm not a very good player, but once I read a book on martial arts (I have a Japanese friend who is a teacher of martial arts), I was impressed with the ideas of how you have to concentrate and focus on the instant, and be a little bit ahead of the coming attack, to attack before the opponent, anticipate, all those things. I read about all of this during the night, and it took a while for this register in my conscious life, but the day after when I played tennis, I tried to respond in the same way, and my trainer was impressed, actually astonished at how much better I was, and I told him it was because I had read a book about martial art. And he told me that American tennis players like Jimmy Connors, John McEnroe and others have been trained in martial arts, which is very interesting. So, there are different references to others and also personal experiences relating to martial arts in this book.

KJ: Would you say that the novel's primary focus is on behavioral matters, sexual obsession, religion, suicide, travels to other cultures such as China, explorations of spirituality, and the role of the arts to name a few things?

JK: Exactly. It is true. It is interesting that you ask this question because the french critics were particularly interested in the personnage d cle [key to the identity of the characters], who is who, etcetera, and this behavioral aspect was not so much emphasized, which is more important for me of course.

KJ: To pursue these matters of sexual obsession, religion, suicide and so on -- since you work as a psychoanalyst and you often listen to various patients and their situations, would you say this book somehow purges some of those feelings? Surely a psychoanalyst must get her fill of other people's problems. Would you say there is an autobiographical dimension to this book and that the book itself is a means to overcome depression, perhaps a kind of "talking cure" or at least a psychoanalytic self-examination?

JK: In a way you could say this. Anyhow, I don't know why I have done this, because it was a sort of imperative, but when I think about it afterwards, I am convinced that it was because I was encouraged very much by my patients, because they build novels all day long, and it was a sort of an encouragement to say "I" in order to come out from behind concepts, and in a certain way to no longer hide myself through concepts, and in a way to be more personal and more naked, and to commit myself.

KJ: Bakhtin once pointed out that the realist novel is monological, you have commented on Chang Tung-Sun regarding escapes from this via a dialogism through a Yin/Yang configuration or by moving into the polyphonic, dream logic, the carnivalesque. It could be said that The Samurai has polyphonic qualities. I was wondering if you somehow tie the polyphonic element in the novel to your own theory?

JK: Well, I was not thinking about the theory when I was writing the novel, but now when I think about it afterwards, and I am trying to present it, I will say that it is very polyphonic for one thing, for instance, there is a polyphony between the three couples, in the novel; Olga and Hervé, present the most apparent and socially recognizable fate of my experience, she is a girl coming from Bulgaria, from a distant country, she finds a man who is the director of a literary review, a well-known French novelist, who is my husband [P. Sollers]; there is another couple, Martin and Carole who are nocturnal doubles and twins of the first couple and who are the most exposed part of our generation who risk themselves in political lives and sexual experiences, and she was depressed and he became a painter and a homosexual and he died finally, and so it's a most dramatic experience; and there is also a third counter-point, to those two couples which is Joëlle and Oren, and Joelle is writing a diary in a most ironic attitude towards society, and so the characters in themselves are very dialogical. For instance, Olga's lover, Mr. Dalloway, who has the name of a female character (Virginia Wolfe's Mrs. Dalloway), so he has some feminine parts in his own personality. 
It was interesting that in the French newspapers, they have never spoken about Mr. Dalloway, because they were interested in French life, and who is Lacan and who is Barthes in the novel, but this more intimate part was perceived as something maybe very personal, or a sort of treatise in comparison with my French involvement, I don't know. Nevertheless, there is this dialogical character which is in my mind an interesting character of a man with a very deep complication of the female sexuality -- it was very interesting for me to build. And it's connected in my own experience with literary characters, so, it talks in a sense about polyphony. There is also a polyphony of places. I talk about Paris, New York. I talk about New York, New York. There are a lot of recognizable places, restaurants, students, outstanding intellectuals from the New York life, etcetera. There is also China of course, and some hints about East European countries. Its a sort of a benevolent space, and the emblem of it could be an island. Isolations, mountain ridges, caps, and in the end of the novel Olga is on an island and it is a very intense experience with birds and sun and it was for me a great pleasure and also a difficult trial to try to describe this aspect of nature, and the involvement of the characters through their sensations with the landscape.

KJ: Yes, I see the fragmentation of the three groups of characters not only through movements in space, but time as well, and for me there is also a fragmentation of perspectives. I wonder if this isn't what we might call a kind of Lacanian "fissure" or split, that somehow has to do with the difference between self and Other and the attempt to bridge the gap between the self and the object of desire, or the Other, and, of course this bridging is something that can never be done completely, and the result is this fragmentation.

JK: Well, once again I can conceptualize this in reference to different things but its just the experience of everyday people, I think. You can take somebody who is not an intellectual, who is an average man, and who has this fragmentation. It is like when you are watching television, and you are zapping, going from one channel to another, and you don't know where you are, you are so multiplied, and I tried a response to this everyday experience.

KJ: Part way through the book you have written that "Nothing is either tragic or triumphant -- it's only a matter of rhythm..." [see:p. 195 -- Ed.]. And so, in the book we have this interesting rhythm of fragmentation and at the same time this paradoxical simultaneous drive towards and against death, so its kind of a cyclical thing.

JK: Exactly, your comments are very philosophical... are you a philosopher?

KJ: I depends on how you want to look at the question [laughter]. So, we have this rhythm in the book, and then the final image in the novel is this little ship in the water and the idea is, if you wait, maybe it will come to you -- a powerful symbol. I was wondering how you resolve this difference of having this death drive on the one hand, and on the other hand have the patience to wait until the wind can change so that the boat can be driven to shore? Is the Samurai of language always to be destined to fight a war to which there can be no outcome? Or, is it a matter of patience, of waiting for the right wind to come along an blow the marooned ship back to shore [see: p. 341 -- Ed.]?

JK: Oh, this is the main problem, where everything is commanded in us by the death drive. Freud said that the death is suggested in every wave of eroticism, the mainstream of eroticism is built, and I get the impression that all of our generation is very aware of this, and still is. Maybe more than generations before, because... different sublimated values of future paradise, harmony in society, all those things appear if not absurd, then anyhow very difficult to build, and we are very aware of the difficulty of building identities, and building links, so, if we are aware of this, sublimation is the way to postpone this accomplishment of the death wish, and to temper it. You are depressed but you have to find the words for this depression -- you are in ecstasy, which is also dangerous, but you have to find the words for this, and this image of the boat that will come or maybe not. When Joèlle Cabarus is a little bit melancholic in this garden, this is an image of how will we deal with our passions awaiting for the words and signs to come in order to nominate the passions. This is the only way to arrive to, and to find the meaning of our passions, and this is why I am writing. Its a metaphor of writing, for the urgency of words.

KJ: In a related matter, and regarding the importance of death, the death of Bréhal, and I assume Bréhal is Barthes [see: p. 301-- Ed.]. And the death of Bréhal is psychoanalysed as perhaps suicide or at least the achievement of the death wish -- this is one way out for the Samurai of words, Seppuko/Harakiri. The other way is to use the words then and in a way wage war against death. Are these the only choices, to use words (or some other form of expression), or to die?

JK: I don't see another one. The other might be to have some ideologies, but ideologists are often very perverse, so, the only thing to do is to try to find the words for our valences.

KJ: For years you were an editor with Tel Quel along with others such as Philippe Sollers. Those must have been exciting times. We were fortunate enough to publish portions of Soller's novel $H$, several times in Rampike. Could you say something about your editing experiences and your relationship with Philippe?

JK: Well, we're still together, and now Tel Quel has been transformed into another review, because they changed the name, and its called L'infini (non-finished). Its a new review that follows Tel Quel, its, maybe you can say, post-modem, or avant-garde because its less formalistic and more involved with some religious and philosophical and moral issues, more literary than formalistic, but I think there is the same exigency, to be true. Tel Quel featured not only theory but art and writing and so on. It was connected, theory and art, it was not possible to make theory without art, it was the legacy of the Russian Formalists, there were always connections, Jakobson was a connection with Mayakovsky, we were a connection, I mean Barthes and myself, we were writing just theory and not fiction, but were in connection with Sollers and all those people from the Tel Quel review and so we experienced a fictional and artistic trial.

KJ: Around the same time back around say, 1980, the revue Poétique was also quite active with people like de Man, Genette, Cixous, Riffaterre and Todorov on their editorial board. It is clear that at times Poétique was concentrating more on critical theory, while Tel Quel was combining theory with art actuel or contemporary fiction and poetry. Could you comment on what you see as the fundamental differences between the editorial approaches of Poétique and Tel Quel?

JK: I would say that Poetique was more of an academic journal, more theoretical and not as directly related to the fictional experience.

\section{KJ: What are your current projects?}

JK: I have finished another novel that is already published in French, and it is translated by Columbia Press, called The Old Man and the Wolves. And its starting point is the death of my father in Bulgaria, actually he was killed in a Bulgarian hospital, its really crazy, can you imagine that, because they don't give expensive medicine to old people, they didn't have enough surgical and medicinal supplies. Even when I asked how he was, they said, "Why do you ask questions? Are you from the KGB?" You see, they had interiorized the persecution and they were really paranoid. And so the starting point was this really grave and tragic event for me, but I tried to transform it into a metaphor for the evil in the world. And in my book, it's a country where people's faces are changing into animal's faces, and nobody sees this, just this old man, and when he speaks about it they tell him, "You are not right. You know what is happening? You are imagining this!" But he is the right person to see all of these things happening, because there are no more values, and finally he is killed, and the novel changes into a sort of detective novel, because there is a journalist coming from France trying to discover what happened. The book includes a sort of degradation of human relationships... and it doesn't happen only in the eastern world. The place is called Santa Barbara, which could be anywhere in the world. So, this is finished, and there is a project now to make a film for French television based on that book. I also have the proofs to a book which is called The New Malady of the Soul. This is a collection of my essays, from over the years, on psychoanalytic things, and I just finished a book about Proust, and I completing a new novel. Those are my projects. What about your projects?

KJ: It's kind of you to ask. I'm doing some criticisms of contemporary writing, and I completing a book of fiction, and I'm doing some performance and teaching, and there's Rampike, and so on.

\section{JK: Rampike is exciting, I went through it and its interesting.}

KJ: Thanks. I'm glad you like it. I'm trying to do something similar to what Tel Quel used to do, a kind of cross-over between theory, pop-culture, art actuel, and mass culture.

JK: Well, the problem is that we don't have to remain isolated from this mass culture, that's why I accept quite often to go on the French television, but in Europe things are quite different, there are still some channels where an intellectual can be interviewed, but it is not as prevalent here. That is why I think that its important to try to escape the ghetto of the avant-garde.
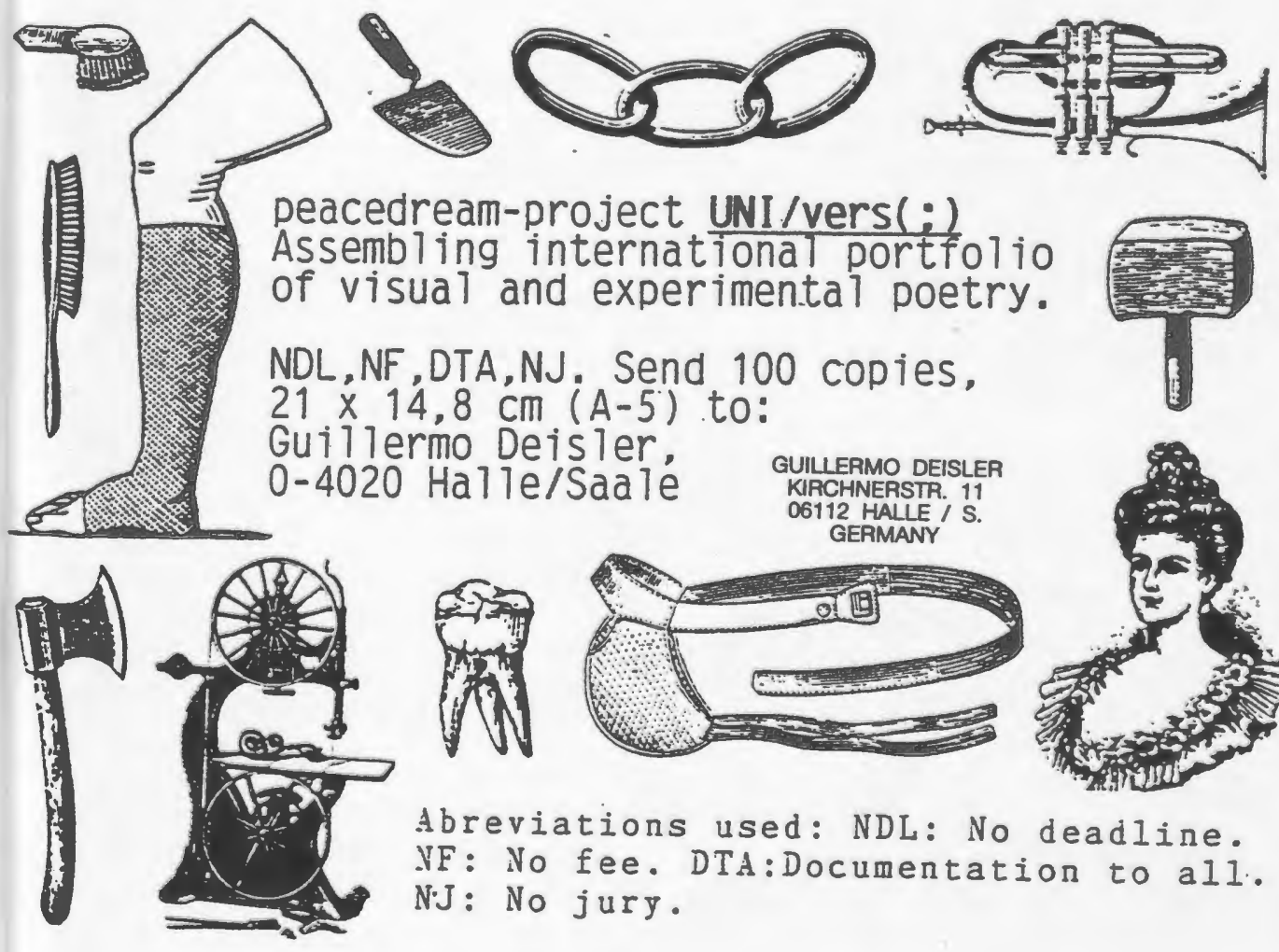

cedream-project UNI/vers(:) Assembling international portfol jo visual and experimental poetry.

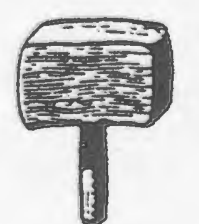

$21 \times 14,8 \mathrm{~cm}(\mathrm{~A}-5)$. to: Guillermo Deisler. -4020 Halle/Saalé LLERMO DEISLER

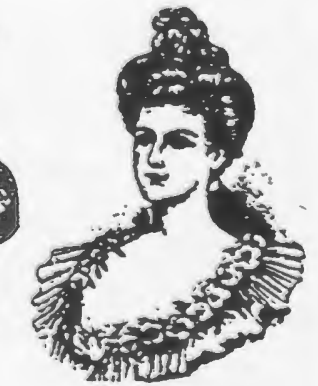

Abreviations used: NDL: No deadline. NF: No fee. DTA:Documentation to all. $\mathrm{N} \cdot \mathrm{J}:$ No jury. 


\section{The SYLLOGISTIC CINEMA by Steve McCaffery}

But it wasn't Garbo's eloquent mood it was Olivier's intelligent manliness and Henry Fonda's power of justice and therefore Carole Lombard's wit.

But if it was Carole Lombard's wit then it must have been Emil Janning's obstinate despair at Henry Fonda's intelligent manliness and Olivier's wit and therefore Garbo's power of justice.

But if it was Garbo's power of justice then it must have been Marilyn Monroe's doomed magnetism with Kein Stanley's sense of worthlessness and William Powell's mutual trust in Myrna Loy's entire pleasure falling short of Groucho Marx's calm acceptance and therefore Fred Astaire's breathless hesitation.

But if it was a case of Fred Astaire's breathless hesitation then it must have been Henry Fonda's entire pleasure falling short of Olivier's mutual trust in Garbo's sense of worthlessness and Emil Janning's calm acceptance of Carole Lombard's doomed magnetism and therefore Marilyn Monroe's eloquent moods.

But if it was a case of Marilyn Monroe's eloquent moods then it must have been Kevin Stanley's wit or Fred Astaire's sense of worthlessness and Myrna Loy's obstinate despair at William Powell's power of justice and therefore Groucho Marx's intelligent manliness.

But if it was Groucho Marx's intelligent manliness then it must have been Marilyn Monroe's power of justice and Carole Lombard's obstinate despair at either Emil Janning's eloquent mood and Garbo's wit or Olivier's power of justice and Henry Fonda's mutual trust and therefore Fred Astaire's pleasure falling short.

But if it was a case of Fred Astaire's pleasure falling short then it can't have been Basil Rathbone's courtly villainy but could be Myrna Loy's mutual trust in Richard Widmark's feigned psychosis and if it was William Powell's pleasure falling short then it can't have been a case of Lee Marvin's complete gratification and if it was Kevin Stanley's breathless hesitation then it can't have been a case of Kirk Douglas's lucid participation in Burtcaster's baroque rage.

But if it was a case of Burt Lancaster's baroque rage then it can't have been Bette Davis's amplified dash by which she dismounts and if it can't have been Bette Davis's amplified dash by which she dismounts then it must have been Paul Schofield's performance in King Lear so then it can't have been Humphrey Bogart's complicated presence in The Maltese Falcon.

But if it was a case of Humphrey Bogart's complicated presence in The Maltese Falcon then it could still have been a case of Carole Lombard's performance in King Lear.

But if it's not a case of Carole Lombard's performance in King Lear then it must be either Paul Schofield's courtly villainy or Fred Astaire's amplified dash by which he dismounts and so a case of Bette Davis's sense of worthlessness in the face of therefore William Powell's baroque rage.

But if it's not a case of William Powell's baroque rage then it must be Burt Lancaster's doomed magnetism and Myrna Loy's mutual trust in Marilyn Monroe's amplified dash by which she dismounts in front of therefore Kirk Douglas's lucid participation.

But if it was not a case of Kirk Douglas's lucid participation then it must have been Groucho Marx's complete gratification or Lee Marvin's intelligent manliness and therefore Fred Astaire's feigned psychosis.

And given that it is a case of Fred Astaire's feigned psychosis then it follows that it must be Richard Widmark's pleasure falling short of Garbo's courtly villainy and therefore being Garbos' courtly villainy it follows that it must be Basil Rathbone's obstinate despair.

\section{FASHION NEWS \\ by Frank Davey}

1. First place in the purchase of underpants is held by Englishwomen, who on average purchase 7 per year. Right behind are Spanish women who purchase 6.2 pairs and German who purchase 4.8. In the rear, at the bottom, at the tail-end are phrases to be avoided. Last, that is, are the Italian women who buy only 3 per year, and no more than one brassiere. All this is apparently true, and published le 27 decembre. Some observers speculate about differences in diet or climate. Others look for correlations with cosmetics, perfumes or cosmetic surgery, or attempt complex analyses of national variations in female self-image.

2. Here in Toronto statistics on underwear sales to men are currently unavailable. This lack is unfortunate both politically and poetically. $A$ Little Night Magic continues at Harper's Dinner Theatre. Men's briefs come in four basic models and in a more limited range of colours. Theatre Passe-Muraille presents The Tyrant of Pontus. Despite radically different market conditions, much interest continues in third-world fígures. Look, sweetie, I heard this on Business Magazine. Men can be divided between those who wear undershirts the year round and those for whom they are at best winter clothing. The Scarborough Village Theatre -- some seats still available for Agnes of God. Brief design has been strongly influenced by the evolution of the athletic support. Jan. 17 - Feb. 8 at Village Playhouse: Sinners by Norm Foster.

3. During 1968-1974, the first period of activist feminism, lingerie, previously the chief medium of feminine eroticism, fell into disrepute, with many women discarding the brassiere altogether. Annie wanted to know who says. In the late 1970 s triumphantly reborn femineity overthrew the old boundaries between undergarments and clothing. A young reporter for the Nice-Matin. Eager couturiers re-invented the crinoline, the waspwaisted corset and the garter-belt, ushering in a period of intense interchange: undergarments could replace the negligee or traditional elements of outer clothing, while the latter could be worn next to the body itself. I told her it was my own loose-fitting translation. The erotic mystery of lingerie became the mystery of what might underlie the visible.

4. On the big night every eye in the hall turned to catch the entry of the baddest girl of all. I will be so relieved dearest, as relieved as I know you will be, when all this is over. Ten pounds of sugar, imagine, ten pounds of sugar. The feminist challenge in art -- if one can be nailed down at all - replaces the monumental and exotic with the intimate and domestic. Do you remember falsies? Alarmed by his mother's new attempt on his life, the prince fled to the mountains and was for many years a hunter. Guelph co-ed convicted after topless protest romp. New medical concerns. Protect yourself, men lie. The free woman, of course, achieves climax without sacrificing her freedom and integrity. Even though I knew it would make you unhappy. 2 cups flour, $1 / 2$ cup brown sugar, 8 eggs, $2 \mathrm{lb}$. raisons, $1 / 2$ tbsp. allspice, $1 \mathrm{lb}$. currants, $1 \mathrm{lb}$. mixed peel, 1/4 lb. ground almonds, brandy. All proceeds go. In the beginning mischief meant calamity, real big trouble.

5. It was his grandmother's recipe. Amid the renewed activism of the 1980s women became less concerned with visible display. In 1990 only 200 million bras were sold in all of Western Europe, with most designed (de-signed, she explained) to follow and enhance natural human contours. English-women were also far in front (in front?) in the purchase of this item, with an annual rate of 1.8 . They were followed by the French women at 1.4, the Spanish at 1.3 and the germans at 1.2. many of those intimate with the industry regard the small size of the Italian market as a mystery. I am just translating what I read. Despite widespread interest, statistics on colour, size and style variations between countries have to date not been made public. Producers of all types strive to reflect social customs. 


\section{PARISIAN HABITATION: POET'S QUARTER TO CHATEAU by Kirby Olson}

Three or four times a day, the Moroccan neighbour goes out to get a newspaper a haircut, or a cup of hot chocolate. His one and a half year old son stands on the landing. "Bye bye," the father says repeatedly, abusing his two words of English. The baby says nothing, and the man is upset -- doesn't the child realize he is leaving?

The father repeats "bye-bye" until at last the child realizes that the father may never be back, and starts to scream his brains out. The father, suddenly pleased with himself, bounces down the five flights of steps to his errand -- leaving the heartbroken child -- who screams for another twenty minutes. The boy's mother, who must hate this balcony scene almost as much as my wife and I, may also feel just as powerless to put an end to it. I fix a cup of tea and think of saying something to the guy again, but the last time he lectured me for twenty minutes, saying, "When you were little, didn't you cry? Why deny my son that privilege?"

All around Paris one finds giant chateaux, where the aristocracy once sat like spiders preying upon the city of Paris. The grounds of Chantilly to the northwest of Paris are typical. Wide canals trace a network of fake peasant villages where the royalty once played at poverty -- their wives and mistresses dressing up as bar maids in the village inns. Black swans circle aimlessly in fountains the size of city reservoirs.

The stables at Chantilly were built for a prince who thought he'd come back as a horse, and are the most outrageous example of utilitarian architecture imaginable. My eyes ached with hay fever all day, but it made my heart mysteriously glad to see this pleasure palace erected on the outskirts of the metropolitan area -- not quite far enough from the mob of 1793 -- which sacked and razed the chateau. Although rebuilt in the late 1800 's by the state, it is no match for Fonteinbleau or Versailles, which retain their original stone. Still, its museum is finer (a radiant miniature Raphael of the three graces holding perfectly spherical apples) and its stables -- made of carved stone and a half mile long and a hundred feet high -- covered with lions and eagles and hunting scenes -- are no doubt second to no other stable in the world.

All day, Bob Wittig, a Fullbright recipient from Seattle, and I gave each other lectures. he told me about Gogol -- the first to use the rambling, seemingly innocent country bumbler as a narrator, I told him about Balzac, and the wonderful idea of the master criminal who so successfully outwits the government that the state is forced to hire him as their chief of police. Rob tells me about the lectures of Jacques Derrida, and how he qualifies everything he says with a perhaps, a maybe, or by putting forth his own ideas in the third person, One would think... I wonder if he does this in bakeries. "One would think that perhaps since I am in this bakery, that it is plausible that I would like a loaf of something, perhaps pain de campagne?" Derrida drives a BMW to and from his comfortable home in the suburbs.

We fed the carp in the moat of the chateau. This is a famous activity at Chantilly according to my wife Joellyn's wacky guidebook, but the writer doesn't say why. The carp have big, orange mouths which are vaguely colourful as they surface, but it is still a mite ordinaire. Do the carp think it weird to receive bread from the air? Probably not any more than we think it weird to get our food from brightly lit supermarkets.

All winter, I've been slaving at my novel while Joellyn goes on long walks through Paris. Today she took me with her -- through the park of open air sculpture. The big blobby lumps of abstraction looked like turds of the gods. Rows of Cartesian logic lined the sidewalks in the form of red, blue, and yellow flowers. In the zoo, a lot of new monkee babies held desperately on to their mothers while their ape moms swung between thirty branches in five seconds. The sea turtle had been in its dirty stagnant pool since the 1850 's. It seemed as if it was in a doctor's waiting room. Depressed beyond impatience - simply Inert.

From there we walked to the Roman arena, built in the 2 nd century A.D. Young men played soccer on one half of the circle, kids played soccer in another quarter, and old men played petanque (a game with lead balls similar to jacks) in the second quarter of the circle. The balls kept overlapping, but no one seemed to lose patience. The three ages of man in such an ancient setting moved me. Joellyn said she wanted to ask the men whether she could throw one of their lead balls. She didn't, but I wonder what their response would have been if she had. It's hard to guess with the French.

A Turkish mosque where scruffy Arabs sit around on Person rugs in dishevelled suits and three-day-old beards smoking hookahs. The fantastic blue mosaic beauty of this interior keeps a coolness in its stones even during such a hot day. Their mosques have a lightness in their aesthetic quite different from the musty, oppressive stone of French cathedrals.

At night, after a dinner I'll never remember, Joellyn convinced me to walk on the bank of Ile St. Louis, by the Seine. Underneath a bridge some clochards had piled mattresses. Some of them were talking gently, others smoking cigarettes, still others were sleeping, wrapped in green army blankets. We lowered our voices and stepped nervously through their living room.

Seattle, a small city by the Pacific ocean which collects clouds like a catcher's mitt. Nine hours later, here by the Seine, a hundred Greek restaurants open on a narrow, medieval street. Meat turns on a bit roast spittle, as beautiful Americans stop to take a look at it. I am so used to opening up my ears and mind to eavesdrop on the French, that when instead I overhear an American saying something like, "Fuck that, let's go to Burger King," I gag; not because of the Burger King choice, but because the accent is so banal, and the thought so familiar, I feel my privacy has been violated. I glide into a bookshop where there's a hidden French tea room in back, where I can get a slice of cheese as bit as a computer mouse, a cup of tea, and the use of three different journals for fifteen francs, about $\$ 2.50$. My money is running out. Soon buy plane ticket for home.

Joellyn has gone to Italy with a girlfriend. I listen, in the dark, to a neighbour woman across the narrow courtyard making love. I get up to go to the window. It is three a.m. Looking up, I see a few sordid stars. Looking down, I see the lit ends of cigarettes in other windows -- other men listening to her make love. The cries of ecstasy have lasted for hours, long ascending groans followed by an orgasmic scream of pleasure. Just when it seems over, it begins anew, not ending until morning when we, unshaven and haggard men, finally fall exhausted into our beds, clutching our pillows.

For months, the Arab neighbour woman has been bringing me over almost tasteless, greasy cakes to have with my morning coffee every two or three days. This morning she knocked on the door, and I expected the same thing, but instead she beckoned me with her index finger to follow her. I went in to her tiny apartment, and she showed me that her TV and radio and sandwich grill didn't work, smiled, shrugged her shoulders. I smiled and shrugged my shoulders too, thinking it odd that she had decided to show me her broken equipment, and went back to my apartment, which was also full of broken radio and such.

My landlord called from Seattle this afternoon and I told him about this peculiar incident, and he said that he always fixed their things for them and that they probably assumed that since I was an American, I could too. I laughed. Electricity is a greater mystery to me than it was to Ben Franklin's dog, if not more so.

Tonight I saw the man I've resented for months, the erstwhile Moroccan, who according to my Seattle landlord is actually Algerian. he was walking the screamer boy on his shoulder. He shook my hand, and held his baby out to kiss me on the cheek. I liked them, at first grudgingly, and then much, a handsome family who had come from a small tribe fresh off the desert and who were living all alone in Paris, and I was sorry I hadn't been more charitable about the level of noise their son had made all winter. He had been teething, the man shyly explained.

Walking like a mule down the old winding steps from my fifth floor apartment, everything I own on my back, my writer's pilgrimage ending, I imagine winning the lottery and sending them part of it. 50\%, 10\%, 100\%? Their share oscillates as I get on the metro and begin the arduous journey to the airport, finally forgetting these neighbours and their decibel level, only to be remembered by my diaries open before me, my forehead pinched. Before I left Paris I had to visit the Pompidou Centre one last time to see the international exposition of the last ten years in painting. After visiting it, I wrote this poem on the back of a postcard of Moon by Francesco Clemente:

At last I am tired of the ancient world, Paris, and everything Not-Paris

I am looking forward to them opening up the new planets

Is not the Pompidou, the city of Genoa and elongated sun-glasses enough?

The trees of Cucchi, drawn as if Rembrandt's mother was a dog on a leash

While the sun bounces through the universe like a red super ball

And Joellyn is over the Atlantic, and I still sit on a marble fountain in Chirac's Les Halles

Like all Republican architecture, there was an eye on the bottom line, And it shows --

Just as in this poem, I'm trying to figure out a bottom line. 


\section{INCREASING FREQUENCY: A TALK WITH}

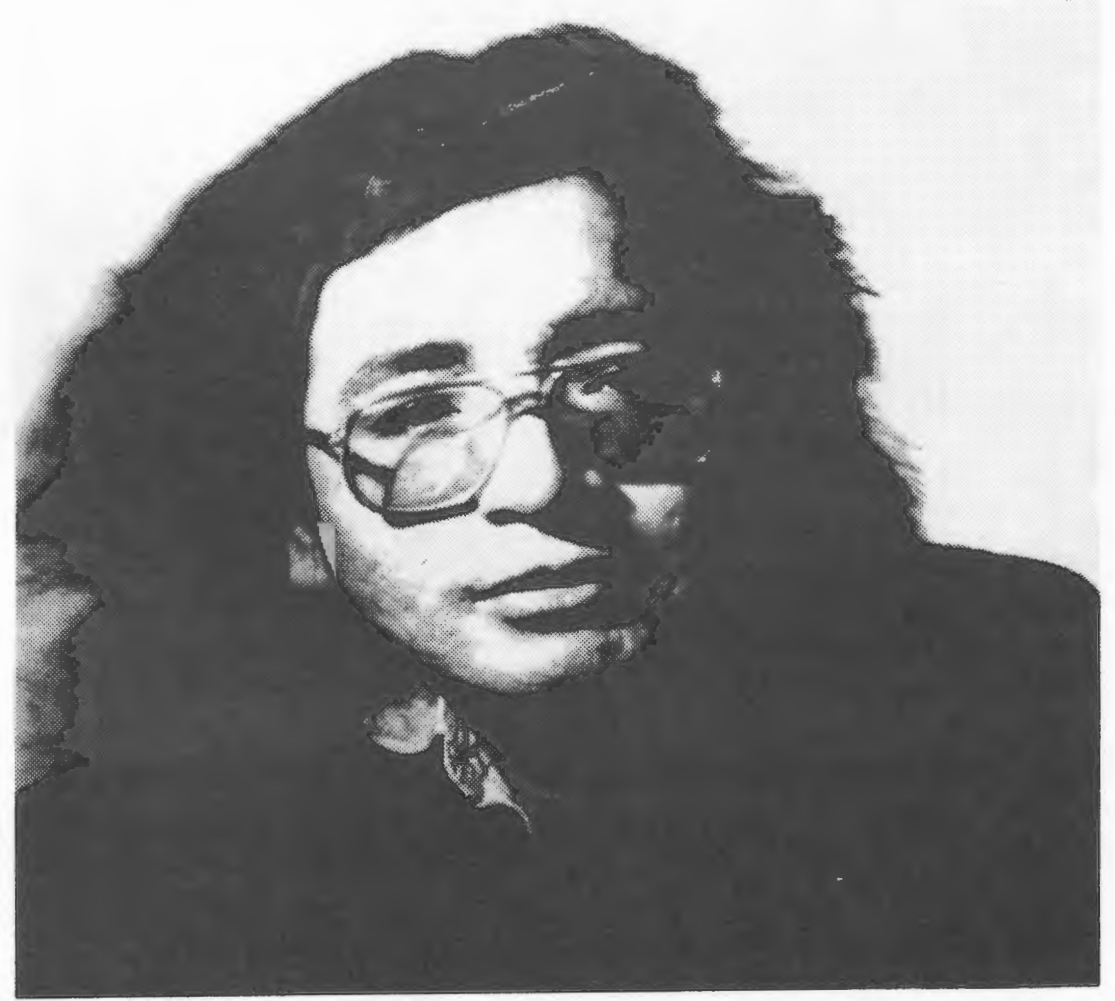

Tomson Highway has been internationally recognized as an innovative playwright. His plays, including the his most recent drama Dry Lips Oughta Move to Kapuskasing (1990), are raucous satires that draw heavily from the Native Canadian storytelling tradition. Each drama has comic and tragic overtones and features residents of the mystical Wasaychigan Hill Indian Reserve. The action is punctuated by unpredictable and sometimes hilarious interventions by Nanabush the notorious mythological trickster figure. Through the trickster we learn of the subtle connections between the mind, the spirit and the body. Dry Lips won a Dora Mavor Moore Award for best new play as did Highway's previous drama The Rez Sisters (1989), which also received a Chalmers Award. The Rez Sisters drew extravagant praise internationally at the Edinburgh Festival in the United Kingdom, and features seven women and the world's biggest Bingo tournament. Born in 1951, on Maria Lake in northwestern Manitoba, Tomson Highway spoke only Cree until the age of six. He studied at the University of Manitoba and University of Western Ontario, and holds a degree in Music and English. He has acknowledged that early in his career, he was influenced by two of Canada's best known playwrights, James Reaney and Michel Tremblay. Since then, he has gone on to gamer international acclaim. Combining knowledge of native culture, classical structure, and artistic language, Tomson Highway brings a unique vision to the stage. He has said that: "Theatre for me gives the oral tradition a three-dimensional context, telling stories by using actors and the visual aspects of the stage." Tomson Highway is currently working on a sequel to The Rez Sisters and Dry Lips Oughta Move to Kapuskasing, which will be part of a seven play cycle. He is a noted director, composer and screen-writer. He has worked with a number of native support groups, and has workshopped and produced his plays across Canada including at the Playwright's Workshop in Montreal and the Native Canadian Centre in Toronto. He has also served as the Artistic Director of the Native Earth Performing Arts Company in Toronto. Highway's next play Kiss of the Fur Queen will be released in the near future. Here he talks about the renaissance of aboriginal culture in Canada. [Ed. KJ]

$$
\text { **** *** *** }
$$

T.H.: English is very much, my second language, I write in it but its a very distant second, it isn't mine, but I use it, its the language I make my living in... and I read today in English, in the paper, about women getting raped in Slovenia, you know the war in Jugoslavia. You pick up the newspaper everyday, The Globe \& Mail or whatever newspaper it happens to be, and you read about people killing each other all over the world, and this is an astounding thing to me. Why is there so much hate out there? And how can it stop? Is there any way that I as an individual can find a way to stop that hate, and stop that war? I can't, and neither can you, as much as you would like to stop the raping of those Croatian women by Serbian soldiers, so they will give birth to Serbians. And they call that "ethnic cleansing." And that's only one small country in the world, and you take a look at Somalia, take a look at South Africa, take a look at Northern Ireland, and its not always the case of people slitting each other's throats, and raping the living daylights out of each others women mostly...its emotional aggression, spiritual aggression, on another level. And you see a bit of that here in this country, you know. During the last election, if you chose to look at it from an extremely negative aspect, you could see, essentially a country ripping itself to shreds. And personally, I find it really incredibly painful to watch humanity rip itself to shreds. No matter where they come from, what race they come from, what language they speak, what gender they happen to be. And we watched the soldiers in Jugoslavia, and we watched the military in Somalia, and here in Canada we watched the politicians...my submission is that neither the politicians, nor the military have succeeded so far in stopping that kind of hatred, that type of human to human emotional, physical and spiritual aggression. My submission is that the kinds of people that can make a major contribution to the stopping of this kind of hatred are artists. That is the submission I am making. I think that we have access to a spiritual language that ties people together, no matter what race, and no matter what language they speak. And that's why so many of us, do what we do. -- I refuse to give up hope of the fact that human beings can get along, that there is some way that we can find a common language whereby we don't have to be killing each other. And just because you've been slapped in the face, and the Indian people of this country have been slapped in the face many, many times throughout history, just because you've been slapped in the face doesn't mean you have to go and slap the aggressor back in the face. My history of going through the whiteman's educational system, in which I did very well, because I listened very well, and I was a great ass-kisser, one of the great lessons, one of the powerful and beautiful lessons I learned was that when a rape occurs, it is not the aggressor who wins, and the aggressed who loses, its the other way around. The aggressor only succeeds in pounding the soul out of himself. And to use a rather broad metaphor, the rapist only eventually succeeds in destroying his own soul, and gives an additional potency to the soul of his victim, and there is truth to be had in that.

So, having said that, I like to give you an idea of the progress of native artists in this country over the past few years. They are going places, taking steps forward. And its interesting because for many, many years, ever since the colonization of this country, there has been suppression, and just to give you an idea, since 1951 there was a law in place forbidding Indians to make drum-sticks, forbidding Indians to put on shows, to put on shows like the pot-latch in B.C., the ghost-dance on the prairies, the pow-wows and all that sort of stuff, and in my reserve in northern Manitoba, when they told us you cannot dance these dances, the missionaries told us, you cannot dance these dances, you cannot perform these rituals because you are speaking to the devil. So, we had a couple of generations of people going around believing that every time we were doing a song or dancing, even a couple of cree dance steps like this [dances here], they were dancing them for the devil. Well, when you have entire generation of young people growing up with that kind of belief system, negative belief system, its no wonder they killed themselves all over the god-damn place. Its no wonder they sniffing gasoline, and taking pills and boiling Kitty Wells records and drinking the liquid thereof. But there was a generation of us who came forward by the mid-sixties and early seventies. There was a group of us from the west, the north, from all over, who dared to say That's Bullshit. We have a right to perform our own songs. We have a right to do perform our own dances, to tell our own stories, to give our own point of view. Then the ground was been broken by a number of visual artists, people like Norval Morrisseau, and William and Daphne Odjig. It was only in the 1970's and 80's that the writers started coming forward, and among those writers were theatre artists, the showplace artists. And then in the 1990's for the first time, we have flesh and blood Indian stars! We have Indian kids on Indian reserves across this country with posters up on their bedroom walls with people like Graham Green and Tantoo Cardinal, instead of Elvis Presley and James Dean. Its such a nice change to see that kids won't be killing themselves with as much frequency as they would have before that. Because they can say, "Look, the previous generation did, we can do it too." And that's one aspect of our cultural development.

And the other thing is that, when I was growing up as a kid, it was really, really hard to stay in school, because all the books were shoved down our throats, and it was always English literature, English literature, everything was about England, or the States, and nothing every happened north of the border, all the cool people lived in either New York or London, or Nashville, or Los Angeles. Nothing cool ever happened in Brochet Manitoba or Sault Ste. Marie, Ontario. And they gave Shakespeare for days, and Tennessee Williams for days, and so on and so forth, and I love those guys, I admire them very much, but we have our own stories too to tell. So, we started writing them down. And lo and behold, maybe we haven't reached the stage where we're as good as William Shakespeare, or Charles Dickens, but those books that we are publishing, those plays that we are producing around the world with increasing frequency (even as far away as Australia people are starting to pick them up), and now those kids going through school don't always have to wade their way through Shakespeare, which is in the language of those who tortured and conquered us, there is no language more encouraging of kids quitting school faster, and what we need is educational material that talks about the cool people of Sault Ste. Marie, or the cool people of Brochet Manitoba. And these are the very reasons why we write, and we couldn't do it without your support [gestures to audience], and your help and without you knowing what's happening every step of the way.

Following his tour of Australia, Tomson Highway agreed to speak in Sault Ste. Marie as the 1993 Hayes-Jenkinson, Memorial lecturer presented by Algoma University College. This talk took place at the Rankin River Reserve -- Oct. 27, 1993, Sault Ste. Marie. 


\section{Two Poems from:} There Are Seven Deer in My Left Shoulder (Underwhich Editions, Autumn 1995) by Rolland Nadjiwon

\section{Fast Horses}

We rode fast horses in them days

told stories in the silent sharing of power

in firelight dancing eye of

our women - old people - children

of counting coup and stealing horses

recounting the time

of young men raiding

the untended night time

moving like smoke of fires

into morning grey dawn

edge of camp

edge of horse corral

on stolen horses

riding thunder

through enemy village

through enemy sleeping

shaking dreams awake

into the magic

of our medicine dream

of our medicine ride

women - old people - children

wide eye

gawking

their morning

\section{dreaming}

the dancing beauty

of our morning power riding

through their village

invisible

in their circles

in their half sleep morning dreaming

Many coup - five horses

out from that day's morning mist

and

riding

riding from horse

to horse

to horse

until nightfall

silent in the sharing power

of that day when we rode fast horses
Mishi-Bijou Sleeping

Great horned serpent awakening into our dreams into our visions

a chimera of power tempting our ancient greed

\section{Grandfather}

your beauty magic songs of creation your sacred arrow songs silently holding the seventh arrow into his seventh coil until we sing your song again to keep his sleeping

\section{or it is forgotten}

and the arrow falls

\section{empty}

\section{Each morning}

each desert sunrise

four times

I remember

sand

mesquite

Palo verde

cactus shadow

I am a desert stranger

My grandfather

is buried

in rich dark earth

under trees

maple

oak

\section{elm}

\section{hickory}

soft fern

near limestone sweet springs too far from here

I am so far from grandfather from his earth spirit

the songs are silent

the drum is cracked

his tracks dusted under

sometimes

at night

he speaks to me in the thunder

or weeps tears of acid rain

Mishi-bijou moves

the sacred song arrow trembles

\section{UN/UNDERSTANDING by Howard Webkamigad}

The message of the message giver comes out from a clouded background, cultural baggage, which is received by the message receiver sometimes garbled because of the many noises, the noise of each, sender and receiver, encoder and decoder, both are of different ages, and both are befuddled by the process, this led to them being uneasy and without poise.

The voice is strong and clear, but the other does not understand because of this dichotomy, which enforces the similar to become dissimilar, and the meaning to be misplaced, to be forgotten in the world which does provide, the message disappears almost dismally, into the realm of the subconscious where it rattles, baffles, but will not be replaced.

The aural connections are unimpeded, they are resounding in clarity, but sees the voice, but not the sound, how can it be, did the eyes see wrong, voice seen but no sound heard, it is odd that this is to be, for in days gone by, the dialect was not theirs by choice, but different from centuries of separation, but now all speak the same, as cows in a herd.

Still the silence curtails any sign of knowing, even when told of the reason for despising, and recognizing the cause for such misdeeds, each feels a sense of loss and foreboding, when relatives meet, they do not acknowledge, each deals with the other not surprising, in a fashion learned from the different other, whose language all speak and promoting.

The elders they do bring to cling to the past, but do not listen, again this is their vice, to pretend to be what they are desperately trying to deny, hide, and send their own children, send their young to another place to learn the ways of the different other, this is not nice, in the eyes of the elder, voice is made but not heard as if sound silenced by the cauldron.

Listen, says the younger, what did he say, you were making too much clamour, I did not hear, says the older, if you listen you will hear, but you must listen, even if you're bombarded, shouted the young, even if I listen, I cannot hear when they make noise, it hurts my ear, but you can, listen with your being, not just your ears, and for this you will be rewarded.

Sounds abound, even in the quiet forest, the growing grasses, trees and waters, very loud, as the air moves through the trees, the music made, happily sing the birds, frogs as waiting, seeing the patience, and impatience of the lonely figure, suffering in the sun, long for clouds, to wet the ground, frogs help by calling down, to alleviate the trees, animals all panting.

These noises someone has heard, and understood and thus answered, but why the disrespect, the elder feels and gets, for his message is from the past, and much too difficult to follow, for the softness has overtaken the people, softness of body, mind and spirit, but suspect, and evilness compound the serenity of the era which can become, but they decide to wallow.

The thunders still roil when in season, the winds still ravage upon the unsuspecting, the elders still give messages to those who will listen, many do not hear, this is untrue, they just do not want to hear, for it is a new age, to wage war and to be disrespecting, where they were in ages past, control, dominate their own, learned from other, must undo.

The message is sent, the receivers decode, something is wrong, soon something will connect.

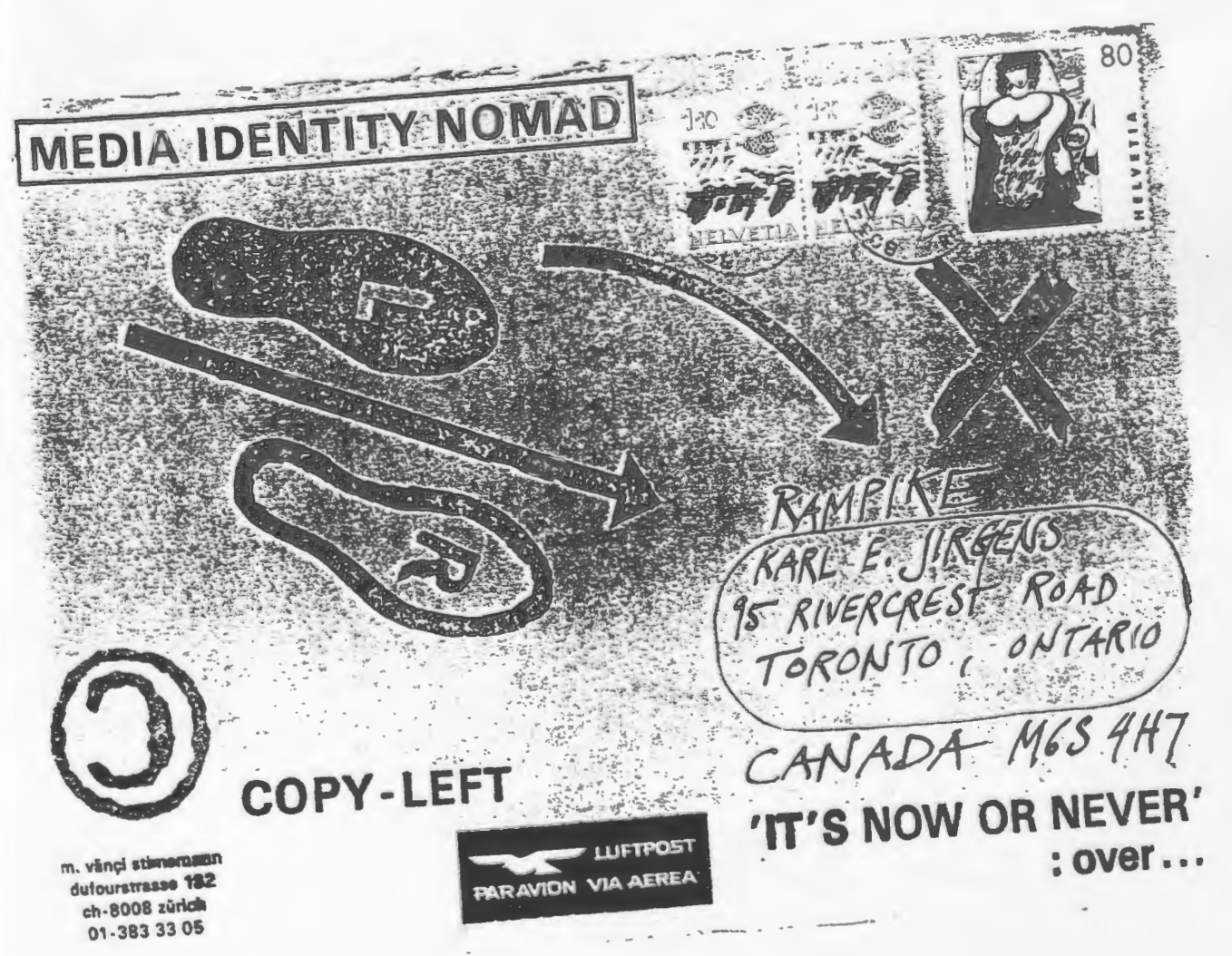




AN INTERVIEW
IN TWO TIMES:
TALKING WITH
CHRISTOPHER DEWDNEY

\section{by Karl Jirgens}

This "interview" with Christopher Dewdney is actually a compilation of separate talks that took place on two separate occasions (August 1993 \& January 1994). The entirety is presented as part of Rampike's historical documents series. Here Christopher Dewdney offers illuminating information about his writing and background. His two latest books are The Secular Grail (Somerville House), and Demon Pond (M \& S). Karl Jirgens' booklength monograph on Dewdney's writing will appear within the year in the "Canadian Writers and Their Works" series (ECW Press) -- [Ed. KJ].$$
\text { *** }
$$$$
\text { *** }
$$$$
\text { *** }
$$

\section{PART 1.}

KJ: I've noticed that your use of words including the manner in which you put together titles is unusual. The technique is juxtapositional and often you combine lexemes in unexpected ways, sometimes you create contrasts through oxymoron or paradox of some sort, or at other times you create unexpected harmonies.

CD: sometimes titles are lines in poems, and vice versa titles will become lines in poems, it all does cross-reference in a funny way.

KJ: Can you give us a "cross-reference" to your personal background?

CD: I was born in 1951

in London, Ontario, next to the coves a geographical feature, a series of Ox-bow lakes, my youth is actually detailed in my introduction to Predator's of the Adoration. Instead of going to a real University, my university was the woods where I spent my childhood, and that's where I was trained. I left there and came to Toronto in 1980 just after my dad died in 1979. My father loved first nations people. My father was lapsed Anglican. He was trained as a missionary by his father

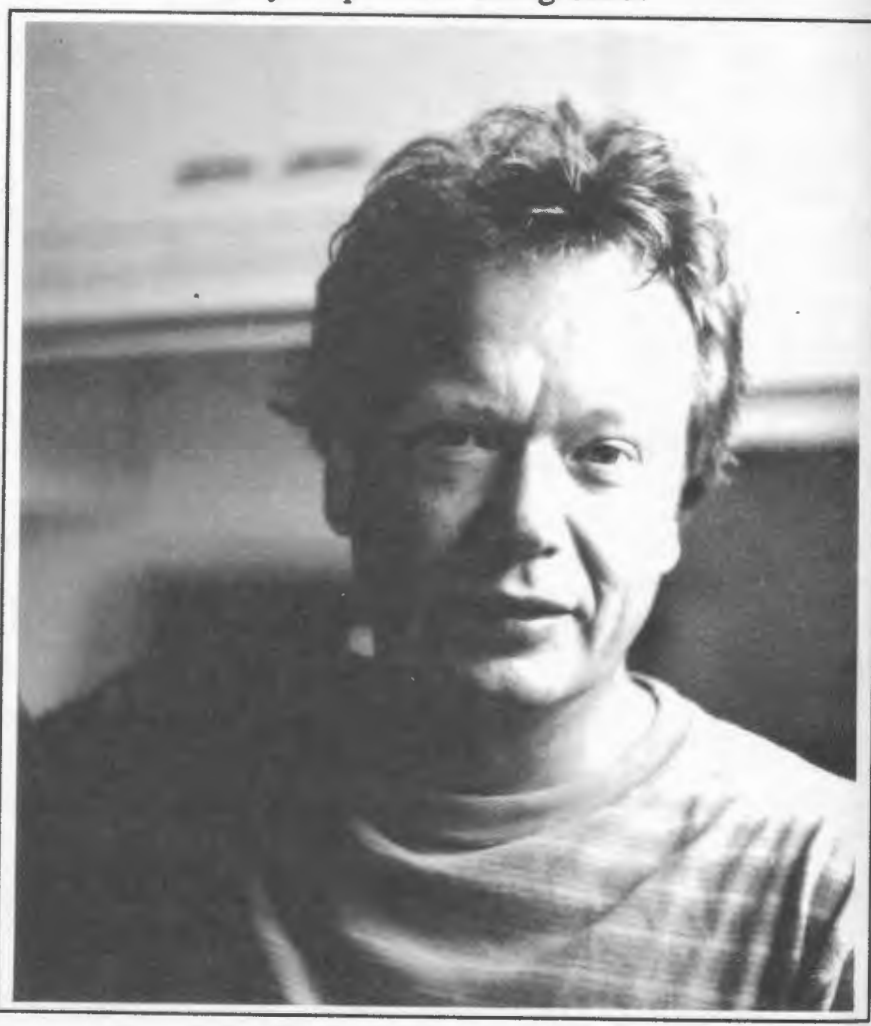
but he left the church and was a humanist, atheist, Nietzschean. I think he became Ojibway after that in a sense, he took on the Ojibway ways. I was raised to honour certain aboriginal beliefs, I was very young, but I remember my father was making tobacco sacrifices to the water to Mishipezhu to make sure the canoe didn't turn over while we were paddling, and that sort of thing. And we were taught the native values, to make repatriation for things that we took from nature, to leave things the way we found them, actually very good advice.

KJ: I think I can see how some of that ties into your writing. I remember a poem in which you are with a group of other school children at a geological site, at a rock face, and you lift a rock and these moths come out from under it, and the moths are a stone colour and its unclear as to whether the moths are simply stone coloured moths or maybe the moths are fossils that somehow have become animated, but it didn't seem to matter because they are of the earth either way you look at it. Going along with this is the sense that the earth is alive.

CD: I'm not sure of the genealogy of those native beliefs in myself, there in there somewhere, I don't know if I kept them discreet or not.

$\mathbf{K J}$ : Can you tell me about your marital life. Is it true that you were instrumental in curing your first wife and perhaps even in saving her life?

CD: I didn't save her life but I undertook a considerable amount of re-habilitation. She had a pretty severe haemorrhage in the left temporal lobe, a sub-dural haematoma, that was quite debilitating, and she was twenty-three at the time, I was twenty-two. And this left her paralysed in one side, caused her to have seizures, couldn't recognize words when she was reading and so on. She was born with a vascular defect, a congenital defect. I did take on her re-habilitation because I wanted to get her back to the way she was. I realize now that I was undergoing a modern neurological version of the Eurydice myth because I was trying to bring her back from hell which was, for her, a state of neurological disintegration, which in a sense never really fully happened, it took years and didn't happen as quickly as I had hoped, although now she is now quite functional and has gone on to do all right, but she has changed.

KJ: Well known author and literary critic, Eli Mandel, felt that you investigations of the human brain marked an important point in your life because around that time and after that, a lot of your poetry began to deal with neurophysiology. Mandel admired that development and he often spoke of how one's life can influence one's writing.

CD: Yes it does, I don't know what I would have done had that not happened. It was definitely a kind of brick wall, because it also took me out this very coddled sort dreamwomb that had never been ruptured. I think some poets go on in that state forever and they keep to an original and natural trajectory, and are allowed to go on unperturbed in this state, I think Clark Coolidge is like that. But what happened with me was this major thing hit, that deviated my trajectory. I can't tell if that's good or bad. But what was good about it, was that I could see how there was a one to one causal relationship between consciousness and brain function and being. And so I studied a lot of medical books and books on neurophysiology, all the way from Humberto Maturana from Chile to David Denett (Consciousness Explained).

KJ: I know that there are a number of authors that you admire such as Cormack McCarthy, you recommended his book Blood Meridean to me.

CD: Beautiful writing. Brilliant. I still like Michael Palmer's work, he's in the United States, also really enjoy the work of Tom Raworth, the British poet. He has a very rapid delivery, he's got a quick mind, constantly shifting frames. I like his poetry a lot. He's had these incredible heart problems, his heart rate sometimes goes over two hundred beats per minute.

KJ: In reference to your own writing, I noticed that you have some very unusual collocations. The connections you make on grammatical level and on a conceptual level are quite unusual compared to other writers.

CD: During conversations, I'll often make connections that seem quite natural to me, but other people find them to be unexpected. There usually is an associative train, but my associative train is fairly oblique arising out of some sort of dislocated strata perhaps. $\mathrm{KJ}$ : You have in your recent book often referred to language in terms of the notion of the "other". Of course, Jacques Lacan has used that term frequently and he divides the consciousness into three parts, the unconscious or what he calls the "imaginary" (not to be confused with things imagined necessarily) the conscious or what he calls the "symbolic", and the "real" or those ineffable aspects of experience that cannot be fully grasped, and it seems to me that what you are doing in your writing is cross over the borders between not only imaginary, the symbolic and the real for example, but other types of physical and conceptual borders. I also see an intersection in your writing between mental or psychic states and spatio-temporal loci (personal past, recent personal and global past and distant global past). So, there is this sense of being engaged in a kind of universal or all-encompassing moment.

CD: Yes, its true, that's very true. Those are conflations of space, and that's very much part of what I do. Its always been there too, its a curious thing, its very consistent. That's why it sometimes seems to me that I have undergone any kind remarkable temporal development because I always seem to be in this one space that was highly defined already through all of these things. Its a sense that has always been there and the Natural History of Southwestern Ontario is perhaps the most explicit reading of that phenomenon. KJ: Most great artists have one major flash of insight, or a single great idea, and then they spend the rest of their lives trying to elucidate that. In literary theory, Northrop Frye is a good example of that, or Marcel Duchamp within the art world. Do you think that you have done more or less the same thing?

CD: I don't know. Its a funny thing. I was talking earlier about that womb-like state where you're occupying something that seems to be quite magical and amazing, but at the time its almost taken for granted -- that is something that I've always dealt with. A lot of what I do is analogous to the "big bang" and trying to encapsulate what happened in the "big bang" through circumstantial evidence in your life. So what you're saying is true. But there was never a single event, instead there were a number of concentric layers of events. Because I'm sort of a nostalgist, although it is a nostalgia for the present in a funny kind of way, I've already said this in Natural History. So there's the past and the present, and the present where I am living now is suffused with present dreams and its already feeding back and forth to some other incarnation, and in a sense, I haven't gotten out of that moment, and so what I do is try to stay there, a kind of childhood regained. $\mathrm{KJ}$ : Although with your latest book (The Secular Grail), there is a considerable shift in perspective.

CD: What's happened with that latest work is that maybe this is the big change, and if we go back to biography, I recently left Lisa (Downe) and met Barbara (Gowdy), and she's a novelist and a very fierce and passionate writer and she has brought a whole other series of concerns to my writing, I've re-examined my work on a number of levels, and now I'm quite a bit more conscious of what I'm doing, not in the sense of being overly conscious of your craft, but conscious of how I'm working. I'm now extending more control into my craft. 
KJ: Without putting a value judgement on it, would you say that earlier you letting language flow together?

CD: Yes, it was much more intuitive, it was just happening. I did that whole book Fovea Centralis just as it came, I hardly changed any of it, I've always worked intuitively and never edited very much. So, what the difference is now, is that I'm comfortable with my earlier work, but I don't think I can work like that now.

KJ: That helps confirm my earlier idea regarding the Lacanian angle and the transition between levels of consciousness, that is, that in your earlier writing you are bridging unconscious and conscious.

CD: Yes, that "mirror stage", I've had that actually happen as a child, but I've had a very existential sense of mirrors all through my life, I've had hallucinatory experiences with mirrors where I've seen myself in a mirror a couple of times, like I've flipped over, or don't know which side I'm on, its a very disturbing, frightening and marvellous experience.

$\mathbf{K J}$ : I think that a degree of eye retention comes into that and eye retention, in a small way, works the same way that some of your writing does, which is to take all of experience as a kind of universal moment, and to try to present experience as a moment rather than getting involved with linear time.

CD: Yes, exactly. The thing about the unconscious is that there is no time, its not linear as well.

KJ: What do you think of the writing of Umberto Eco?

CD: I like him.

KJ: I was wondering, because you have forwarded several theories on language that seem related to Eco's ideas. He talks about the relationship between sender and receiver, that in some ways connects with your "parasite" and "governor" idea.

CD: Yes, that's from my essay. That essay haunts me, I don't know whether to abandon it or stand behind it. Because I use these metaphors there sending poetry and receiving poetry, and poetry coming from the outside in the sense of the "other" which is still an important concept for me, that is, to think of poetry as coming from someplace other than the self, but that goes back to the Symbolist notion that poetry can't come directly from the self.

KJ: You have step outside of yourself, or step outside of the ego in a sense.

CD: Yes, and that's where a Zen Taoist view comes in, because you can't achieve important things with the ego in the way, you're own attachments and desires get in the way.

KJ: And that's not too far away from the North American aboriginal view.

CD: Yes, that's true. They come from a very real humility which is based on enormous respect for nature because they're completely dependent upon it. They have a very pragmatic humility, which is different from a spiritual humility which is more abstract or philosophical.

KJ: Maybe your writing in your latest book does display and ego, unlike your earlier writing, because it does locate or posit an "I".

CD: Yes, it could be that I've achieved an ego for the first time (laughs). In a sense I've undergone a change because of the presence of that "I".

KJ: That's interesting because then you can play the "I" off against the absence of an "I", and I don't know how far you would want to go with this sort of thing, but you could be talking about being and non-being and so on, not necessarily literal non-being, but things like consciousness and unconsciousness, which is what you've always been playing with anyway, its just that now its more defined.

KJ: Sometimes your earlier non-ego based texts enter into the real upon their conception and in their alterity become the locus of your "other". But now, by writing from an egobased point of view, then, in one sense, the audience becomes the "other".

CD: I've always felt that I don't write for an audience, but now I find that I increasingly am because the audience has intruded on me.

KJ: You like doing public readings don't you?

CD: I love doing public readings, I love working crowds

KJ: Because the instant feedback?

CD: Yes, there is a "group soul" at any reading that has a lot of energy to it, I really enjoy that. In a sense its a performance, perhaps I've evolved and part of my work is that, I do a lot of stand-up stuff, entertaining, the last time at the Rivoli, I told the audience that I had a fax machine connected directly to my shredder, and I don't even read it, I get a message from somewhere and it gets shredded and everything is fine.

KJ: What about Einsteinian views, do you think notions of relativity fit into your writing in any way?

CD: I'm really interested in things like Quasars, and time. But I still haven't quite figured out the phases of the moon, eclipses. I mean really figured them out. I love this idea that knowledge, real knowledge is something that you know corporally, you can know the phases of the moon mathematically, you've done it at school and you could pass the test, but to actually have it make sense, to know that you're on the surface of the earth, and then this happens, to pass the test inwardly, not semantically, and its a constant battle to teach yourself the knowledge that you've learned intellectually and to understand it on the deeper levels of your body, to know things, that's what I'm trying to do right now.

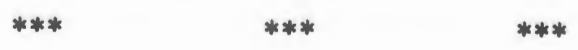


sceptical of writers who "disavow" earlier work, meaning that perhaps they shouldn't have committed their early thoughts to paper and therefore that their judgement was off and therefore that perhaps their judgement is still off because a writer who has something to learn will never learn what is essential. I don't know, perhaps that notion impedes real learning, which can only be based on admitting ignorance in the first place.

At any rate, the main thrust of "Parasite Maintenance," was that consciousness and language are physiologically based phenomena that bear the earmarks of their biological genesis, and that is something I'm still trying to elucidate now, and is, therefore, a concern that I could never fully disavow.

KJ: Could you say something about the fact that you have been labelled a 'pataphysician by some people, and why you have stated that is a misnomer in your case?

CD: I love to read 'pataphysics and see 'pataphysical productions, several of which I participated in myself. It is a natural genre for me, though, those sections of my own work that others perceive as being 'pataphysical in spirit are not actually 'pataphysical because, well, my intentions are more serious where 'pataphysics is light. In some very real sense I stray into Science Fiction I suppose, though again, without any real investment in the eternal, adolescent moment of Science Fiction. In another sense I have a lot in common with Surrealism and to a certain extent Dadaism, genealogically at any rate. But there is something frivolous about 'pataphysics, the subjects it treats are somehow ephemeralized by its lampoons and my business isn't exactly satire in that sense. I would like to be able to create logic traps, linguistic manipulations of the causal realm of the reader, steps that lead them irrevocably into cul de sacs of reason to bring about a change in their world view, now just to challenge it.

KJ: When you speak of the "immaculate perception" I assume that you are discussing a type of synaesthesia, a self-conscious and total-body perceptual experience, something along the lines of a continuum of sensory experience not unlike the state one might achieve under meditation or perhaps after ingesting certain mind-altering substances.

CD: Yes, the "immaculate perception" is about experiencing the world as a human being experiencing the world a human being. It is about acknowledging the sensuousness of our nervous system, our perceptions, as we interact with the world. In a sense, it is a celebration, Dionysian, and yes, it can be inebriated in the hallucinogenic perceptual realm. The book, The Immaculate Perception, seeks ultimately to elucidate the illusion of selfhood, as does the Secular Grail.

KJ: Did you or the editorial board have a particular mandate when you were co-editing Provincial Essays, and what do you feel were some of your greater accomplishments in regard to that project?

CD: Provincial Essays was a quirky little magazine that really had a peculiar editorial board. Greg Curnoe had a regional agenda, Jennifer Oille was coming from Vanguard, and Oliver Girling was a real down-home in Toronto Queen-Streeter. It was a very pluralistic board. It is no longer happening. That it went as long as it did seems an accomplishment on its own.

KJ: The first issue of Provincial Essays details some of your early experiences in London Ontario including visits from well-known artists and prominent figures such as Greg Curnoe or Norval Morriseau or Stephen Lewis. Could you say a bit more about that home environment and how it might have affected your earlier perceptions?

CD: I had an extraordinarily rich home environment when I was young. My parents were friends with an amazing assortment of scientists, artists, and writers, so that, for London, Ontario, I had a fairly sophisticated upbringing. This circle included Lionel and Margaret Penrose, Carl Atwood and his family, Milton Acorn, James Reaney and Colleen Thibaudeau, Greg and Sheila Curnoe, Jack and Olga Chambers, Norval Morrisseau and others. My father, Selwyn, worked with the Royal Ontario Museum as an ethnoarchaeologist specializing in recording native rock paintings in the Canadian Shield, as well as research into the Midé shaman societies of the Ojibway nation. He was a novelist, having published a successful novel called Wind Without Rain in the late 1940's. Prior to that he had executed some wonderful oil paintings, most of which are still in the family. My mother, Irene, was an art therapist, along with my father. They both worked at a clinic in a London, Ontario hospital. She also had an interior decorating show on local TV that I remember seeing in the aftemoons when I was quite young, three or four years old, that came on just before "The Lone Ranger." Needless to say, I have been raised with a profound border-blur between domestic and media realities.

KJ: In Demon Pond you continue to address many of the concerns raised in earlier books, perceptual matters, cognition and so on. I see a split between mystic and empirical perspectives in your writing, but I was wondering what you thought of as your main concerns in this latest book?

CD: Demon Pond...is a strange book. It has pieces about angels and time-travellers and alternate worlds. There are poems about the wind, a few actually, and poems about ghostlike beings and poems about memory, the world and consciousness. It doesn't sound like the work of an empirical materialist like myself, does it?

\section{Seeking. The Long Journey Home by Karl Jirgens}

[This text was part of an inter-media installation at the Artworks Gallery in Collingwood, Ontario (spring of 1995). "Seeking. The Long Journey Home" is also Collingwood, Ontariod in Jirgens' latest book, A Measure of Time, Mercury Press, 1995].

Today I read a story about the handsomest drowned man in the world. About how they found him when he was covered in seaweed and jellyfish tentacles, and only after they removed the flotsam and jetsam did they realize that it was a man. It was the after they removed the flotsam while playing along the beach. But it was the men who children who had found him while playing along the beach. But it waster they cleaned carried him to the nearest house, some remarked his hair, and cut his nails and shaved up the body, the women dressed him and that this man could only be named Esteban, he him. When they saw his face, they knew that this man could onl the neighbouring villages, looked like an Esteban, but search as they might through all the neighbouring villages, they could not find any relations. He was large and heavy, and the villagers undout what a burden this must have been throughout his life, even as it was a burden unto them in his death. But they could not find who he belonged to and rather than send him back as an orphan to the sea, they invited people from all of the neighbouring vill they covered chose a family for him, with parents and aunts and uncles and cousins, and held a great him in wild roses, and jonquils and aspidistra, and hibiscus flowers, and held a great procession and gave him the grandest burial at sea that had ever been'seen, his body returned to the slowly drifting tide, continued its journey, rocking gently on the soft gray waves. For years after that, travelling sailors would pause by the cove and pe

their telescopes would say, "There, see, that is the village of Esteban.

I remember my first summer as a lifeguard with the harbour police. We were asked to scull the heavy wooden dories about the muddy waters of the inner harbour, for practice more than anything. Once beyond the breakwall and out into the open water, practice more thanger, we had to row up and around a buoy and then back again, no easy the 3 foot chop, the sculling oars catching wave tips every fifth stroke throwing off the rhythm, but somehow through the splashing and cursing we all managed to get off the rhythm, but somehow through the splashing ackets with the words LIFEGUARD are the even on the hottest days in order to protect our emblazoned on the back. We wores made us practice with the hook and line. The hooks skin from burning. Sometimes they made us practice with the here were twin rolls of were large, about the size of a fist with nasty barbs on them. There were twin rolls of long lines that were spaced about a yard apart on a drum mounted at the back of the boat. The idea was, one of us would slowly scull, while the other released the line into the gray waters of Lake Ontario. We were dragging the bottom, and being somewhat naive and only too willing to take orders, we never bothered questioning the job. The money we earned bought us things we would normally not think of, flashy shirts, perhaps motorbikes, but most of all, freedom. We would take turns unfoisting the lines, occasionally getting jabbed by hooks still on the roll. Once, I was partnered with a guard who had been at this job for about five years. I said, "Why do we have to do this hook trawling business?" He looked at me like I was an idiot. "Well, we ain't catchin' rish, I kin tell you that." He explained that sometimes travellers in boats or a small aircraft are lost and presumed drowned and we were practising retrieving stiffs. "I get the picture now." I said. But he said, "No you don't. Not until you've pulled one of them up from the bottom." He waited for a while and we kept unreeling the hooks. Then he spoke again, "One time, I remember, there was a guy got drunk and went down somewhere inside the breakwall. We knew he was around the point there, and we knew, after a few days maybe he'd pop up, all bloated. Or, he might just stay down there. Its funny, there dosawlin' for to be any rule to it. Anyway, this guy was a sinker, we figured, so we started trawlin' for him. I was the oarsman that day, and a pal of mine was layin' out the lines. Anyway, we kept snaggin' things like rocks and once in a while an old water-logged hunk of wood. The wood made us nervous and excited at the same time. It would come up kind of slow like and it was pretty heavy. So we never knew what we had until it got close enough to see. We got lucky that day. My partner was haulin' in the line, and as I looked over the

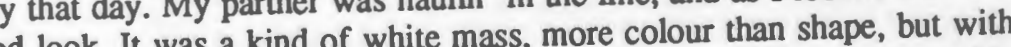
green weeds drifting off of it. It was our sinker and he was all puffed up, his eyes wide gen wut kinda bleary lookin'. So we pulled the body up side the boat. Then it was up to us to get him in. We weren't sure how to go about it and there were no gloves in the boat We tried to haul him in with the hooks which had snagged in his shirt and pants, but. tear loose. Once we thought we almost lost him, he starting drifting back into the darkness, but we hauled on the line and got him snagged again. Anyway, I got fed up with the whole thing, and reached over the side to grab him. When I grabbed him, I could feel my hand pass right through his flesh to the bones of his wrist. The flesh was so feel my hand pass rent jelly. My hand was underwater at the time and as I saw his fingers break the surface I panicked and hand was underwater at the time and as I saw his twisting motion, but couldn't hook him again. Wnother team hauled him out a few days later." I didn't say much after my partner had spoken. For the rest of the day, we trolled mostly in silence, pausing only to put on tanning lotion or to have a drink from the canteen.

I remember years ago, at a lake near Peterborough Ontario, we used to go swimming at a place called Sandy Beach. One time, I remember running along in knee deep water and stepping on a broken bottle. By the time they hauled me into the cedar 
strip boat, the blood was pouring out of me faster than they could hold it back, even with the beach towel. The bottom of the boat was turning blackish red. My parents were horrified, and thought that I might die, but I was only screaming out of pain, and because I would have to cut my swimming trip short. It wasn't as bad as it looked. Another time, when I was even younger, maybe three or four, we had spent the day on that same beach without incident. It was a pleasant enough day and it was time to head back to our campsite. The boat smelled slightly of fish that we had caught, and my father warned not to step on the reel and tackle. My mother was drying my hair with a towel that was wrapped around me, while my father piloted the boat through the Trent canal markers. His hand gripped the throttle on the 12 horse power Elto outboard mounted on the back. I loved the roar of the motor, the bounce and spray of waves. Wind and sun, light dazzling the eyes, dancing on the water. There were bulrushes and wild rice in shallower parts along the lake. Sometimes you could sight a family of loons, but they would duck under upon being approached and would re-surface only after we had passed. At times, the shoreline was so close I could see the milkweeds and dandelions bristling in the sun. At other times, the shore receded and seemed distant, a sliding green blur. My mother asked me if I had rinsed the sand out of my bathing suit and I said yes. But when she checked it was clear that I was bringing some of the beach home with me. I told her that I would be all right until we got home, but she insisted that I strip so that she could clean me off. I reluctantly agreed. She could see that I was still covered in wet sand. She looked at my father and complained, and he responded, "Hold him over the side, that'll rinse him off." He slowed the boat somewhat, but kept cruising. I could see what was coming and tried to scramble away, but the boat was small and there wasn't much room for manoeuvring. My mother quickly trapped me and firmly gripping me by both wrists swung me over the side of the boat and held me in the wake. The water rushing under me was pleasant, and cool, and I didn't mind it that much. Once in a while she would flip me over, to make sure that I was clear of sand. She held me for what seemed longer than necessary, perhaps because she thought I might enjoy it. As I was hanging there over the side of the boat, watching the sky, I looked over and saw my parents yelling things at each other. Because of the rush of water past my ears, I couldn't make out what they were saying, only that the conversation was fairly animated. As I hung there, it struck me that my mother might lose her grip, and that both of my parents were insane and that they had no understanding of the risk that they were putting me to. At this age, I could only swim a few strokes of dog-paddle and often relied on inner tubes or other flotation devices to keep me afloat. We passed a channel marker, a large black log, with reflectors at the top end, anchored in the water. I started squirming and looked over my shoulder. I thought that if I could break my mother's grip at the right moment, I might be able to dog-paddle over to the next marker. I realized that my timing would have to be very good, because at best could swim about ten feet. But the channel was fairly narrow and because I had travelled this route frequently, I knew roughly when the next marker would come by. There was a chance that I could break free, and if I had the strength, I might make it to the marker Of course the next step would be a problem. I could hold on to the marker for some time, but I would be naked, and unable to make it to shore. I thought that I might be able to flag down some help from a passing boat. The whole time I was thinking this, it never occurred to me that my parents might return for me. I decided to make a break for it, and began to twist violently. My mother looked surprised but understood that I was trying to get away. She pulled me on board and shoved me back into my towel and told me to stop acting like a fool. For the rest of the way home, I sat there, with the wind blowing past me, watching in silence. My mother, her face turned toward the setting sun, my father, his grip on the throttle.

I was getting a coffee in my kitchen weighing the jobs that faced me that day I thought that I might weed the lawn, or perhaps write a chapter to my book. Or, if it was warm enough, I might bicycle down to the local swimming pool and go for a dip. There is a different world under the surface. It is a world that seems silent at first, but after a while you can tune into other sounds, bubbles emanating from your mouth, your heartbeat, the movement of your body through the water, splashing from other people. I remember when I was very young, using a mask and snorkel for the first time. I had small green flippers on, and hung in near weightless suspension journeying in the sun-warmed shallows over a strange new landscape. I drifted back and forth through small fringes of seaweed that swung lazily with the action of the waves. I saw minnows darting between shadows and rays of sunlight rippling on the sandy bottom, there were fresh-water mussels protruding, some with small semi-circular paths behind them. As I hovered over the bottom, I felt I was flying over the desert, tiny ripples of sand corrugated the bottom into wavey dunes. It was as if I was swimming and winging at the same time. I had a momentary flash of what flying fish must sense as they soar suspended over rippled waves, the tropical sun no longer obscured by shimmering water glinting its clarity on dozens of irridescent piscine wings, a scintillation between elements. As I hung suspended in my warm liquid environment a perch would chance by, or sometimes a larger fish. When I was young I had a number of aquatic heroes, but one of my favourites was Marilyn Bell. Marilyn Bell was the first woman to ever swim across Lake Ontario. It was an arduous journey. She had been swimming the same rhythm for many hours, a regular front crawl stroke, stroke, breath, stroke, stroke, sometimes the rhythm broken by a hand caught on a wave, an occasional sputter to catch breath, stroke, stroke, breath, stroke, stroke, hour after hour. They say that when she was plying the waters, when she was slowly approaching the sleepy town of muddy York reaching the three-quarter mark of her swim, the sun penetrating the gray waters beneath her, her body started to enter into a kind of rhythmic ecstasy, her mind entered an almost purely meditative state, and with the skyline of Toronto almost visible, she began to see things, simple things at first, a sudden movement somewhere deep below her, simultaneously frightening and intriguing, perhaps the movement of a large fish, occasionally the sun breaking through the clouds to penetrate the depths, setting up grid-like sheets of light that entered her vision as her eyes moved rhythmically from sky, to surface, to depths, to sky, to surface, to 列 looked like a depths, breath stroke, stroke, and that after a while the bottom of the lake looked like a huge chessboard to her, and she began hallucinating giant chess pieces, a complete game started passing through her mind, rook to King's pond seven, Queen's knight to the defence, a brilliant strategic game, with spectacular dashing moves, in the tradition of, say, Michael Tal, the great Latvian master, Tal the terrible they called him, because of his Michael Tallingness to sacrifice major pieces in order to capture the opponent's King, some thought him mad, and after a while the chess game ended, and Marilyn would be a little closer to the far shore, breath, stroke, stroke, and the water grew Mere people playing golf, there was more shallow, and slight wa putts, an entire green, with eighteen holes and caddies and player surine day, and sizing up the shots, the lay of the green, almost perfect in the warm submarine doward the Marilyn swimming like a bird above them, watching the ball move inexorably toward the hole and plunk! into the cup, a perfect stroke, stroke, breath, stroke, stroke, breath, and she said later that they had noticed her swimming overhead, and didn't seem to think there was anything particularly strange about this, and they waved to her and beckoned for her to come down and join the game, and she thought, how wonderful it would be, to swim down to the green depths and whack a few balls, and get away from this insane the lake anyway, and it seemed like golf would be a nice change of pace, stroke, breath, stroke, but then she would start laughing and thinking about what the coach and her trainer and her companions in the

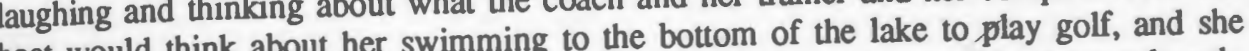
would be laughing almost uncontrollably until it was almost impossible to get a breath, whe but she just kept swimming, and somewhere there is a photograph stroke, stroke, breach, all vintage nineteen-fifties of her after the race surrounded by girs and prizes and such, all vintopardstuff, a television, a car, it looks like a British car, an Austin, a clock-radio, a leopard skin-coat, probably not an imitation fur judging by the period, a hi-fi system, an skenter, a bowling ball, a phonograph player, a pure-bred collie, a set of golf clubs, and sitting there in the middle of it all, player, a purilyn, beaming up at the camera, with a beckoning smile, Marilyn, 1 think it was smiling the way that the people on the golf cours we she approached the warm, gray, smoggy shores of Toronto, breath, stroke, stroke, the waves gently undulatir the telephone rang.

It was a call from a very polite gentleman who mentioned that he had seen my name and face in the newspaper, he apologized for calling out of the blue but had heard of me through a cultural organization that I belong to. A friend of his belonged to the of the death of a Doctor Jirgens in Germany recently, a woman physician, and I said no, I hadn't, he said it was in the newspaper, and he had recalled seeing my name and picture hadn't, he said it witarity between myself alongside an article about my writing, and Victor Jirgens. He wondered if perhaps it was my and an old friend of his by the name of Victor Jirgens. He wondered if perhaps it was my father, and perhaps that my father might have been related to the physician who had recently passed away. I said that it was unlikely because although I have a slightly unusual name, I was familiar with most of my relatives, and as far as I knew I didn't have any relatives living in Germany. He said, well, it was possible, and that if I were related then he and I would be fairly close relatives as well, and what is more, the old Victor Jirgens and Doctor Jirgens' side of the family was quite well off, in fact remarkably well established financially, and that prior to the war they had a huge resort, re the he or was a the go fishing there. He recalled a beautiful forest that was by the lake and there was a windmill and a water wheel driven by a stream that stretched up into the forest on the nearby hillside, and during the summers as a boy he used catch forelles, what we call pickerel or wall-eye, and other times he would put tubes fashioned orth the big

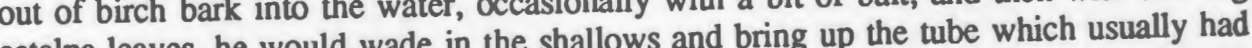
a bit of a string attached. And he explained to me over the phone that he would pick the a bit of a reel if there string up with the midde two toes on his foot, and as he ratalpa leaves on both ends of the tube, they had the biggest freshwater crayfish there you ever saw, he said. Anyway, he knew Victor in the days prior to the war, and he said old Victor was a handsome guy, he knew Victor or could have if he wanted to, and he wouldn't have called me except for the similarity in the photo, and I don't think of me wad's name wasn't Victor, and neither was my uncle's. But just then he asked me my age, and I told wasn't Victor, and neither was sow sous about my age, but, him, and he said, hmmm, that didn't sound right, that his own son we well, maybe old Victor had a few kids that were with a couple of beautiful sisters that lived long after the marriage, he used to be in love with a couple of beautiful sisters that ind when he married near his old home town, and used to see them whenever he could, and when he married
the physician, everything was fine, but he couldn't stay away from temptation, but then, no, that didn't make sense because a bastard son probably wouldn't have the same last name, although you never know, on the other hand, he could've been my grandfather, and at the moment, but, that Victor did sound like the right kind of name, I recall it being something strong-sounding like that, Victor, or Theodore. And he suggested that I look some to my ear I asked a few into it, and maybe give my dould explain who he was to my father. And while I stood in 
the kitchen listening, I was drinking coffee and gazing out the window at the dandelions swaying in the sun. And he started telling me more about the history of the region that he grew up in, and about the war, and how Victor's mother had given his family a lot of help during the invasion, and how she helped his family escape. How his own mother and father, who were quite old by then, were caught in the midst of this senseless war, the Russians moving in rapidly, and how Victor's mother had seen to it that all of their stuff was packed up, their valuables and so on, but that there was no way to get them out, because by now they had been encircled. And while I shifted the phone to my other ear, he explained how his friend Victor's mother had arranged to get some horses and carriages, and with these he was able to sneak his parents through to Riga which hadn't been captured yet and was on the coast. And he explained how he was with his parents in the cart led by the horse heading for the shipping docks where they planned to board an ocean liner for England, or Canada, or America, whatever there was at the time. Just get out. But they had to have an exit Visa -- the absurdity of this restriction during a war, when the Soviet tanks are lined up on the border occurred to them, and there was a lineup of people four abreast running at least two blocks up the street and the chances that they could get out would be almost nil, so, because he was in the army, he decided to pull some rank. And it occurred to me that he had yet to tell me his name. Or perhaps I had missed it at the beginning of the conversation. And so he led his old mother and father in military stride, alongside of the line-up and up the well-worn stairs, two floors to the crowded office of the bureau where they were handing out the Visas, and he explained the situation and the fact that the boat was leaving immediately and they saw that he was in the army and they stamped a couple of papers right there on the spot, no questions asked, and off they went to the docks, and by the time he had cleared them through customs and cleared the papers with the ship's captain and so on, their belongings were all in a big suspension net swinging high over head and being pulled aboard by a crane and were being slowly lowered onto the deck of the ship. And he told me that he watched them go up the narrow gangplank into the big oceanliner and that then he moved alongside of the ship where he watched them on the rail waving with tears in their eyes, the mother's handkerchief waving in the breeze, and the ship slowly pulling out of the harbour, and then he had to go back to his regiment, his leave was over, and the ship never moved from that spot in his memory, always departing, the hanky waving in his mind forever. And he spoke slowly and deliberately and repeated that it could tum out that we are in fact relatives, and I deduced that he must have married someone in Victor's family, but I wasn't certain of this. And he mentioned that there were three minor provinces to the north of the region in which the estate was located, and he mentioned that I may well be an heir to that estate and he explained that it used to be called Velka Muiza but had been changed to Vaidavas Muiza. "Muiza" means "manor", and I know that a "Velkons" is a tug-boat, but I'm not exactly sure what "Velka" means, but somehow, in my own lexicon, it means something like "welkin" or "cloudy". And "Vajdava" is just the name of a region, but "Vajadzigs" means something "indispensable", while "Vajat" means to "persecute". And I listened carefully as he explained that these were historically significant names, and that the three provinces were set with one near the Estonian border at the northernmost part, and it was called Imara I believe, and the one in the middle was called Idoma which means "in the middle", I think, and the one to the south bordering the estate was called Antence or something like that, and he said that there is a smaller estate on the north side of the lake near Vaidavas Manor, which incidently is where he grew up as a kid. And as he was telling me all of this, I had a vision of the countryside broken up into a kind of grid-like formation, not unlike a huge chessboard, composed of irregular-sized pieces. He explained that his folks lived nearby, and that the site is called Pilskalns which means Castlerock, and that is the pseudonym that he sometimes uses when writing articles, but that he uses Metimna as a pseudonym in his books of poetry, three I think he said there were, two formed a sequence, dating from 1940 to the present, the first is about a journeyer, and the second about a seeker who is trying to track down the journeyer. $\mathrm{H}$ eexplained that one of them features a "Burtnieks", or typesetter, who listens to a story, and it's about a John's Day celebration, which is the same as the summer solstice celebration also known as Saint Jean Baptiste day. But he said that in a book there are limitations and that he could only envision for example a small portion of poetry/dialogue in which the typesetter/narrator talks of the John's day revelries with singing deep into the night, and dancing, and lovemaking in the ferm bushes, and food and drink and bonfires and so on. And because it is the longest day and shortest night of the year, everybody tries to stay awake until the sun rises, because this is seen as a kind of triumph against death, a kind of bacchanalian resurrection. And he said that he thought he might set the conversation between the journeyer and the typesetter against a video of an actual celebration, because John's day is such a metamorphic and aleatory thing, and this would be one way to capture it. The celebration takes place each year, but although they sing songs each year, they sing different songs, and although there are always dances, they do different dances, and so on, so how you can you pin it down to a few words in a book. He said that somehow you have to convey the life of the thing, and a video background would help, maybe, for example. John's day, I thought, what better way to measure the progress of time than through an endless revelry always set on the same rainy-hot mid-summer days in June? And I had to stop him for a second because the cat was tangled on her leash, the line wrapped in amongst the wild roses at the back of the yard. The cat's name is Adelaide and she is a calico, orange, black and white, that we found dehydrated and starving and orphaned on Adelaide Street East in Toronto. And I am keeping her on a leash attached to the clothes line for the time being, because she is pregnant, a surprise that I was unaware of when I brought her home. And after I got back to the telephone, he mentioned that he wasn't quite well and that he was calling me from a bed, and that he probably didn't have a lot of time left, but that he hoped that somehow he had made a useful connection for me, and he'd be pleased to meet a blood relative after all these years. I told him that I'd look into it, but that I doubted it, but that I appreciated his concern, and I also felt a different kind of kinship to him and asked him more about himself and his writing. And he said that nowadays he was sick, but he wouldn't let on exactly what it was, but he mentioned that he hoped it wouldn't be pneumonia in the end, because that would be too much like death by drowning. But he said that he was active when he was younger, and that he had travelled widely. He mentioned that in the old days Latvian culture had been influenced by the arrival of the Doriesi who in English we call the Dorians, the same ones who had passed through ancient Greece and who had introduced architectural and sculptural lines that were smooth or streamlined, without rough edges, and had introduced a lot of motifs, such as the Auseklis a criss-cross pattern which symbolizes the morning star, or Venus, and he explained that there were other Latvian patterns that could be traced back as far as India, many centuries ago, and that the Indians and the Jutes, I think he said it was, and the Kurgans, had come to the area now known as Latvia, and had influenced the culture of the existing peoples, the game of chess for example, had arrived by the first millennium, and was a popular pass-time among rich and poor by the time the capital city of Riga was built in the year 1205. He enjoyed a game of chess once in a while, he said. And he said that the cultural background is quite fascinating from a historical point of view, and he mentioned that he had been to Greece once and there he saw a series of sculptures, phalloi, each as high as a person, and in hollows inside the top were wrought iron Auseklis patterns, a sort of modified grid, that held burning oil lamps. A haunting sight at dusk, quite remarkable he said, and he told me about a scandal involving a woman in Florida who had been writing and had recently received a prize for writing in Latvian, and that he had looked at this in the newspaper Latvia Amerika Latvia in America, and the Montrealas Zinotajs, the Montreal Gazette, which had included a portion of the text, and had not thought much about it, but that his wife, an avid reader had looked over the story because it was a portion of the prizewinning novel, and the portion was called "test by fire" or something like that, only in Latvian of course. And that after she read it, his wife flew to her husband who was in his study, flew like a "zvirbulis," a sparrow, he said, and she said that this story that was excerpted from the prize-winning novel, had been plagiarized directly from Lucy Maude Montgomery's Anne of Green Gables series, and he called the editor of the Montreal Zinotajs, and suggested he check such and such a page and chapter of this particular book by Montgomery and see what he thinks. And that's exactly what the editor did, and the next issue featured an apology to the readers for the scandal, and the news got out to the Latvian Boy Scout Federation which is the one that awards the prize, and they stripped the Florida writer of her award, and she tried to explain it as a kind of unconscious recall, cryptomnesia, I'd guess, but as he put it, the more she said, the deeper she stepped into her own deception, and it became clear that she was lying. And I switched the phone to my other ear, and as I did, I flashed a thought about Eli Mandel, who once told me how in school he had told his teacher he was going to deliver a talk at a public speaking contest, but instead he played hooky, and then the next day, when the teacher asked how he had done at the contest, he went into great detail about what a struggle it was, and how after a brilliant oratorical delivery he had won first prize, and it was while he was saying all this to his teacher that he had a flash thought, and realized that he had the makings of a great writer because he suddenly understood just how close fiction and lieing lay to one another, and when I put the receiver to my other ear, I remarked that he had a remarkable way with words, and he said, well, he'd love to hear from me if I found anything out about my familial background, but he asked me to call him only in the aftemoons because he wasn't feeling too well these days. And I said I would, and thanked him for his concern over my livelihood, and possible inheritance, and he said "nem par labo" which roughly means "all the best" or more specifically, "take it as it is given, with the best of intentions". And then he said goodbye.

I thought about his call while I was weeding the dandelions in the garden. And after a few days, I called my father, and learned that there had never been a Victor in our family. I was saddened by this news, not because of any inheritance that might have been involved, but because I felt a kinship with this man who had telephoned me out of the blue, and because I sensed that he felt that he was alone. And I always meant to call him back or visit him, and then sit and talk, and maybe play a game of chess. And soon after I did call, but only to tell him that I didn't think we were related. Still, I hoped to visit him, to grip his hand, to talk awhile. But soon after that I got married, and we moved out of the city, and in the transition, I have misplaced his number. Sometimes, near the end of the day, I gaze out my kitchen window and at the white roses and think of this man that I have never met. Think of the bright image of a boy with a string between his toes raising an unbalanced tube of birchbark out of the sun-bright waters of a near-forgotten lake.

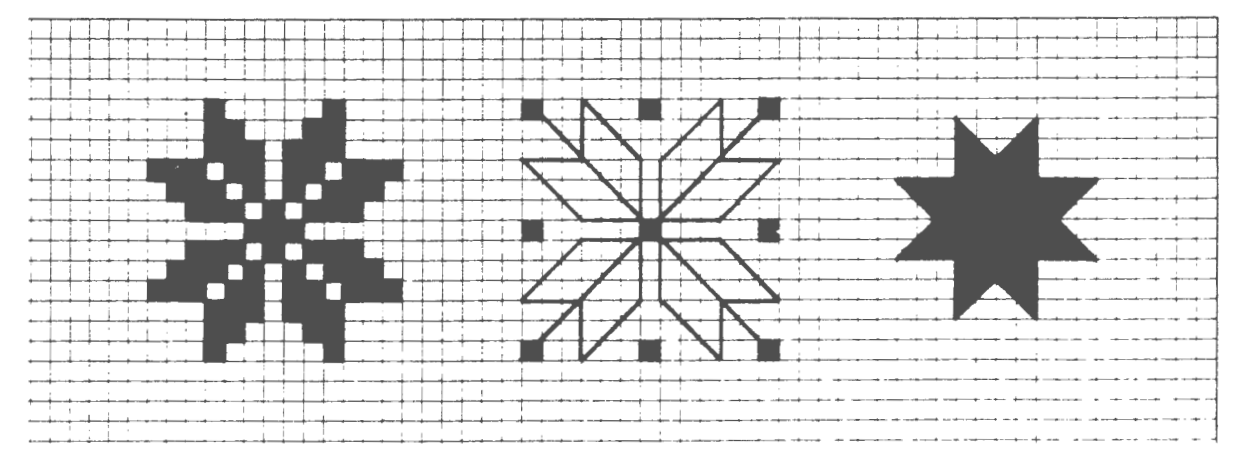

"Auseklis" or "Star": traditional Latvian

motif common to numerous world cultures. 


\section{The Skogekär Bergbo Homeophonic Translations by: Jackson MacLow, Dick Higgins, Alison Knowles, John Cage, Steve McCaffery, Miekal And, Charles Doria, Giulia Niccolai \& Liz Was. Literal translation by Bengt af Klintberg -- Edited \& assembled by Dick Higgins}

The following is a historical document presented to Rampike magazine by the Institute for Creative Misunderstanding. These Bergbo translations have been edited for the "Creative Misunderstanding" issue of Rampike by Dick Higgins. Rampike is delighted to present Dick Higgins' introduction along with a series of "Homeophonic Translations" by internationally acclaimed writers and artists!

\section{INTRODUCTORY NOTE}

\section{by Dick Higgins}

In 1981 Robert Kelly and I began work on a book to be called "Sounds Like," a collection of what he called "homeophonic translations," that is, translations based on sound and on the interaction between the words of one language and the imagination of someone using another language. The field is not new; it was practiced for humorous effect by Mark Twain and others. The book would have had some theoretical texts, by Kelly, myself, McCaffery and Roman Jakobson, a historical section of poets like Ezra Pound who used the style, a chrestomathy of more recent people such as Charles Bernstein, Charles Doria, Ernst Jandl, Ron Silliman, Ronald Johnson, William Benton and others, a bibliography, and a round robin poem of a quatrain by Kelly translated by various poets from one language into the next, entering, departing from and reentering as many languages as possible. But perhaps the most intriguing section was a series of parallel translations of a sonnet by the Swedish baroque poet, Skogekär Bergbo; the poets who sent in translations all transmuted Bergbo into their own style in revealing ways.

"Sounds Like" became overweight and unclear; was it scholarly? Was it a book for the lay reader or for specialists? It became stalled in 1984 as both Robert Kelly and myself gave other projects priority. Correspondence with the perhaps fifty poets we had invited, as well as rights questions, became horrendous. So the project languished until, one morning in September 1990, Alison Knowles asked about it. I thought to myself, "Gee, at least the Bergbo group ought to make its way into print."

And so it has.

Barrytown, New York

\section{SONNET \#92}

by Skogekär Bergbo

Hon kom, all klädd $\mathrm{i}$ hwitt, in widh dhen låge stranden i föllte aff andra tre och sökte wathet swalt, der som thet war mäst lungt och grunt och rent noch smalt, dher som thet war mäst klart uthöfwer skära sanden,

som är kring Mälars haf. Til the lustfulla landen the had' en lögeplatz i såmmarwärman walt, nu til ett tijdh fördrif hwar mannan öfwertalt, medh klädren up til knä hwar annan höll' $i$ handen.

Snart lades klädren af, snart sqwalpa the och praska - the lilliehwijta lår och been nu wältras om så säkr', at ingen sågh och kunde them förraska,

när iagh, af skogen täät wäl höld, när in til kom och - thet ey kunde förr medh theras willia ske nu fick aff lyckans gyunst altsammans noge see.

\section{A ITERAL TRANSLATION OF BERGBO'S SONNET}

\section{by Bengt af Klintberg}

She came, all dressed in white, unto the low shore in company with three others, looking for the cool water, where it was most calm and shoal and clean and narrow, where it was most clear all over the pink sand.

which is around the Lake of Mälar. To these lustful lands they had come to choose a bathing-place in the summer's heat, they had persuaded each other to this pastime, now with their clothes up to their knees they held each others' hands.

Soon their clothes were taken off, soon they leaped and splashed - their lily-white thighs and legs now welter about so sure that no one saw them and could surprise them, when I, well hidden by the thick forest, came close up to them and - this could not have happened with their will $\leftarrow$ now could, by the grace of fortune, carefully see everything.

\section{BERGBO'S 92ND FREELY}

by Jackson Mac Low

Hon', come, all clad in white, in with 'em, logy! strandin' in folly of fonder a three oak socket rather it swelled; ( their sum that messed cleared otherwhere scary sandin';

some air! cling, Melors' half! Till the lust full o' landin' the head in lurky places in Somers, where men welled, now, till it tithe further if on, an' earth were telled meth clutterin' up till kin e'er were on, an' hurl in handin'.

Snort, ladies clatterin' off, snort! - squaw'll paw the oak: pray ask 'e the lily which tallow or oak been new well trashed 'em so secret, at ink, ' $n$ ' soak oak under, then fair ask 'er,

nary a hag, of a scone agin Tet well held, ne'er in till come oak - that Ike under meth as Willie a ski -

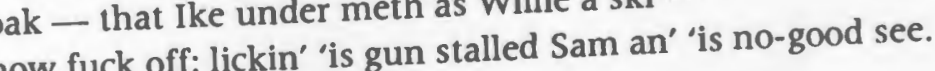

\section{SUMMIT \#92}

translated by Dick Higgins

And Honey came, with the ale of wheat from which the loggers strained; Her mother's off with another trio who soak the wealthy swells They're somewhat moist, they lunge and grunt or rip and smell They're somewhat moist, clear only when they send parcels.

So she had a ring from Mälars, till that lustful lad Had tea in the logging place - it was somewhat warm, he wailed Now ate his overripe and overtoasted cheese it was enough, with clothes-brothers up to him, hollering and holding hands.

Smart lads are clothes-brothers, smart squaws, too, they practice itTheir lily-white leers show they've been waitresses-

"Say, Sugar, ain't no one said you could forsake me.

Naw, Iago, if you squeeze my tit or hold it till I comeOuch! That I can fart with my ass, that you shall see. Now fuck off with your licking and goosing and saying nothing!" 
by Alison Knowles

How come, all clad in white, in wide dense leg a standin' in folds half angled the ox sat swathed in salt, Dared some that were most tongued ox grand ox rent ox smart, Dared some that were most clear, earth over scattered sand,

Some are crying millions have. Tell the lustful landing They had a lodgeplace in a summerwarmèd vault, new till it tied for life where any offered all, My children up till now were any whole and handy

Start lads, children all, start swapping the ox prize - the littlest witch like ox being waltzed on So seek her, at Indian sage, ox country them forsaken

Now laugh, as spoken that will hold near intercom $\mathrm{Ox}$ - they are country for my theories willing sake new flake of lichens 'gainst old seamens' nugget sea.

\section{BERGBO SONNET \#92}

translated by John Cage

No home, all child it with, in width then long strands in folly, half launder tree oh pocket tacet salt, red moss that was just length, o grunt oh rent o callet moss that was just redder, lark rewoven stark in sands, moss rat brings mailer's half. Lit the last of all on lands the day in low places is warm summer tall unlit it death core drift where no one over hamlet match children lit up ink where no one hill if hands.

Smart ladies' children have smart polyps, the oh poor you - the illustrated lark, o been unwaltz rash ohm so scared at night. Say oh candy them forecast who near ah, have poking quiet law held near in lit up home, oh - that they educate for match there as will he ask unflicked half snacked, stung all the same as anger mask.

\section{SONNET \#92}

translated by Miekal And

Yon coma, all clad I write, in wide then logic stranded I footle eff and ra tree ok shooter wettest swart. their some that war mast lung ok grunt ok rent mocha smelt, their some that war mast claret ok hoof wear scare sanded.

some are cringe Mailers haft. Till the lustfully linden they had a logos plait IU samurai war man waltz, my till edit tilde for drift war manana offer tall, mead clan rein up till chun war Amman hole I handled.

Snort lauds children aft, snort squeal pa the ok prays Chad - the lily eh Ehig Ta lair ok been mu welters omsad shark, at ingenue saga ok chutney them for raz Chad,

narc laugh, aft skag an tact wall hold, narc in till coma ok - that ay chutney for mead their is williwaw skew mu flic $k$ eff lick and guy nest alter sampans nog see. home come all twill e white, inwit then lay the strands she fellate off another three ox sukkot with the salt there some that ware mast lung ox grunt ox rend salt there that wear mast klant utherwiderhoffer scared sands

some are king Muliers have. Tyll the lust fallen lands thee had' in loggia place e swimmerwarmer waltz new till tided it foredrift where manna offerhalt mead cauldron up till now wore annana hole e hands

Snared laddies kildreth off, marts squelps thee ox praxa - the littlewhite lare ox been new waldrus home say sacker' at engine sag ox cawed them force ka

near yak, off skag and tat whale hold, near in till came ox - that a cuneate for mead there as will he sky now faux off lick hands grunst altsalmons noggy sea

\section{SONNET N. 92}

translated by Giulia Niccolai

Hong Kong. All clad in white in with the longer strand I fell off another tree or sucked the water's salt the sum that was mostly lungs or grunt or rent or small that sum that was mostly clear out over scary sand

some are cringing to Mailer's half. Till the lustful lands that had waltzed in the logging place in the summeronly till it tied forth was it another oven tart made clear up to the knee it was another hole I handed.

Smart ladies children of smart scalps the eyes prank - the lily with your leer has been a new waitress so sacred at inklings say then kindly to be forsaken

near yeah half spoken that wall held near in till we came or - that eye for me there could as well ask now fuck off like ants' guns. Altmann's gonna see.

\section{BERgBo TRANSLATION}

by Liz Was (Elizabeth Was)

Hun tun, all c lad in huet, in width then lager-straddled i fold often three oak socks with salt,

the son that nwarms my lungs each grunt each rant notch smelled, there some thought war must clear otherwheres Karen's sandle.

Some are careening mylar's half. Till the lustfallen landed they hadn't lounged a plates i swarm-a-swarmin' welt, new till ate tidbit for drift her ware mama overall, medium children up til neigh her wart annual hollihanded.

Snort ladies children of, snort squaws the oak plastic - the lillie-widget lurch being knew waltzes on sad sâké, at ingot sag ache coondog them forrested,

Never Iago, oftspoken twot wall holds, never intercom oak - that a kind father mend their ass with a ski now fuck off lycanthrope gymnast ought shamans nugget sea. 
TRANSLATION OF SONNET 92 BY SKOGEKÄR BERGBO

by Steve McCaffery

On coming, all clad

in white in

woven long strands

if,

fairly often rather oak sucked

weather swelled their soma that were missed

(longed ochre grunt rent oak smelled)

there's some

that were mist coloured (however scarce) and some who were carrying Mahler's half.

"Toil the lustful land

and the hardened Logos plates!"

I seem a woman Walt,

new toilet tides for drift and war

an honour foretold, made clay to run up

till never a holy hand on

smart lady's cauldron of

smart squall up a thick pure ass.

Gather, lily white, a low

rock bean in Walter's home.

Sea sick or a tension

Saigon can do then,

for asking nearer a fast keg

and taut wall held

until comic

$$
\text { - that, }
$$

I can's forbid

as well as I

there,

asking you fuck off

a salmon's nougat sea.

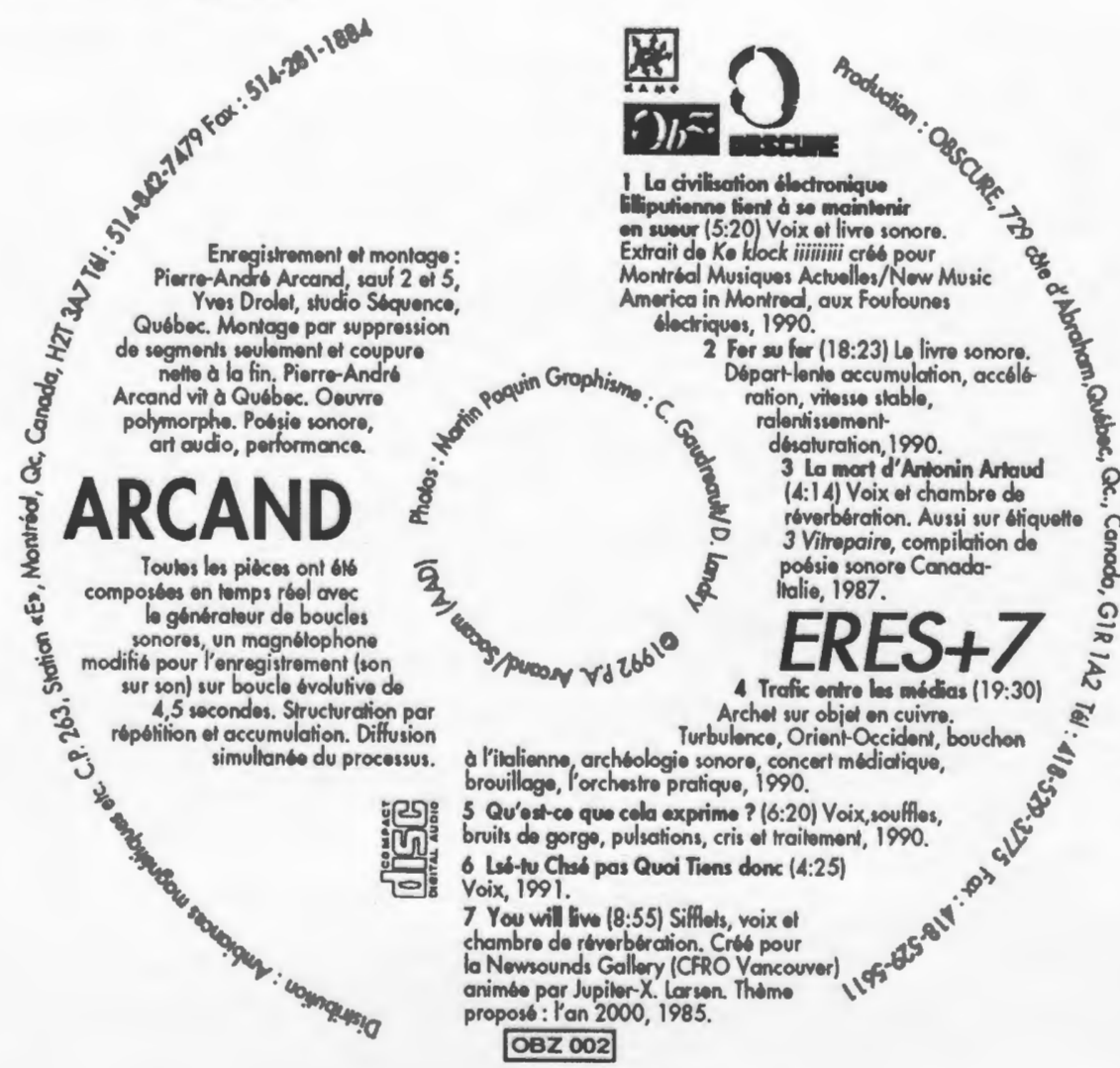

S U B S P H Y S

\begin{tabular}{llllllll}
\hline & $T$ & 1 & $T$ & $S$ & $I$ & 0 & L
\end{tabular}

\begin{tabular}{llllllll}
\hline & 1 & $U$ & $T$ & 1 & 0 & 7 & 0
\end{tabular}

T U T E L

$\begin{array}{llllllll}K & N & I & C & U & N & \text { I } & \text { V }\end{array}$

N I C K I V E

C K K N E R S I

N A

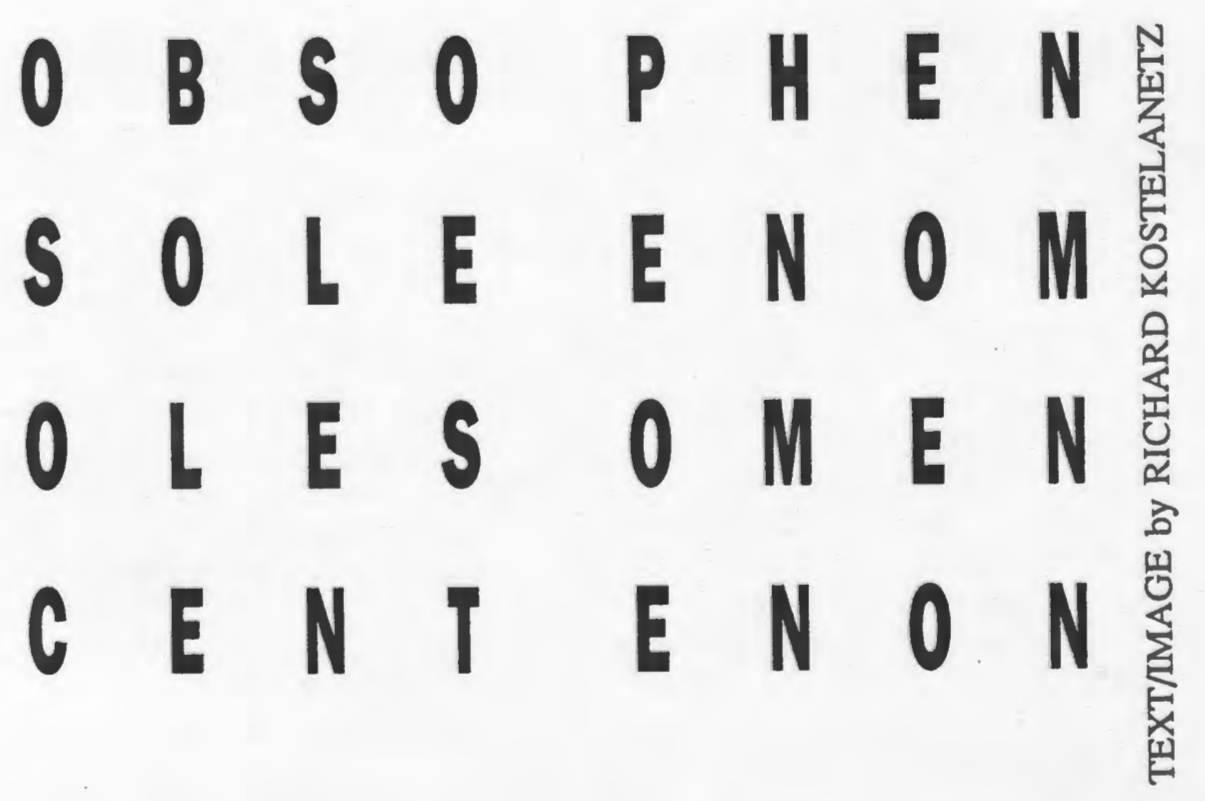

$\begin{array}{llllllll}B & R & O & K & U & N & C & E\end{array}$

R O

$\begin{array}{llllllll}K & E & R & A & T & A & I & N\end{array}$

R A G E I N T Y 


\section{THE COSMIC TRAIN: INTERVIEW WITH PEPE TREN by Juan Opitz and Rosemary Sullivan}

"Bounded by cordillera, by the ocean, by the desert, and by the icebergs. There's no way of squeezing out of it." That's how the novelist José Donoso describes his country. And perhaps that's why Chile seems so self-sufficient: a country where people are used to inventing their own reality.

We're heading for San Alfonso in the Cajon del Maipo to visit Pepe Tren. It's not much of a town: a post office, a store, a restaurant. We turn down one of the streets that leads to the Maipo river. The overhanging eucalyptus almost touches hands and gives a sense of a country lane. This was where the hippies sheltered in the sixties. Pepe's house is typical: it could be any age, a country house of cement with iron grill work on the windows. One has the impression of roses and padlocked fences. But on Pepe's adjacent yard is something fantastic: old train wagons, dating back to 1900 , and a maze of train tracks backed against the dramatic rise of the cordillera. Pepe's obsession.

Pepe Tren (his real name is José Zagal) is a professor of chemistry and a researcher at the university of Santiago, but he is also a poet, a musician, and a man who loves trains. Six years ago Pepe Tren declared himself President of the Society for Preservation of Railroads in Chile. He scoured the country for old train wagons and eventually found what he wanted in Talca, a city three hours south of Santiago. He hired haulers and got official permission to close the highway in order to lug his coaches to the Cajon. He laid the track and began his work of restoration. Every detail must be authentic, of course, and so he searches the countryside for light fixtures, stained glass for the upper windows of the dining car, carpeting. His trains are a complete house; there is a coach library, dining car, bedroom, all in various stages of completion. He has not yet found a steam engine to pull the coaches -- most have been destroyed -- and now he is constructing one of his own. His train needs passengers, and so he is making mannequins of all his friends. He buys the forms but sculpts the faces himself, and they are uncannily accurate masks of recognizable neighbours. He collects memorabilia, and has caps and buttons from many of the world's famous stations. He is a happy man, working amidst his phantom passengers, playing the Irish bagpipes and constructing his private monument to Chile's history.

$$
\text { *** } \quad * * * \quad * * *
$$

R.S.: Let's begin at the beginning: Who are you?

P.T.: I was born in Talca in December, 1949. I went to school there for twelve years and then moved to Santiago to study chemistry for two years at the Technical University of Santiago. Then I went to the States and studied there for three years. Now I work as a scientist, a professor at the University of Santiago, doing research and teaching.

R.S.: And what's your name?

P.T.: My name is José Zagal and my nickname is Pepe Tren, Joe train, because I like trains.

R.S.: Let's talk about trains. What has your life to do with trains?

P.T.: I've liked trains as far back as I can remember -- thirty years ago when I was a little kid in Talca we went to the beach and the country by train all the time. Trains were more famous then. There were steam trains, which I liked very much. They stopped the trains in 1980, and most of the small branches are gone now, but they still have some tourist trains and I still do trips in steam trains. My interest in trains went to sleep while I was in university, but then I got back into it, collecting small trains, HO models, trying to reproduce the Chilean trains which are a mixture of American and European models. But somehow the small trains were not enough for me because is was difficult to reproduce reality in a small scale. I know very talented people who can do that, building layouts, but... I still have my HO trains and from the States my G trains, that are about 10 times bigger.

R.S.: Was anybody else in your family crazy about trains?

P.T.: No. My father used to take me to the Talca Station on Saturday mornings to watch the trains passing by and I remember seeing those huge steam engines coming down the track but my father was not that mad about trains. Obviously when I was a kid I asked for trains every Christmas, trains and trains and trains. They thought I was mad. R.S.: Were you?

P.T.: I don't think so. You have to be mad not to ask for what you want. They gave me trains for three Christmases and then they didn't want to give me any more trains and I was very upset about it. When I went to the highschool somehow the hobby went to sleep but when I finished university I picked up a train magazine and the whole thing started again. This time I bought more expensive ones because I didn't have to ask my parents any more.

R.S.: What happened when you came back from the States?

P.T.: I came back from the States in 1978 and then I started cooking in my mind the idea of having real trains but obviously you have to save money for that because you need land to put the trains on. In between, I travelled back and forth to the States and worked in New York and I saved some money there. Finally I bought land in San Alfonso. This is a very special town. Everybody is very crazy like me, not about trains but about different things.
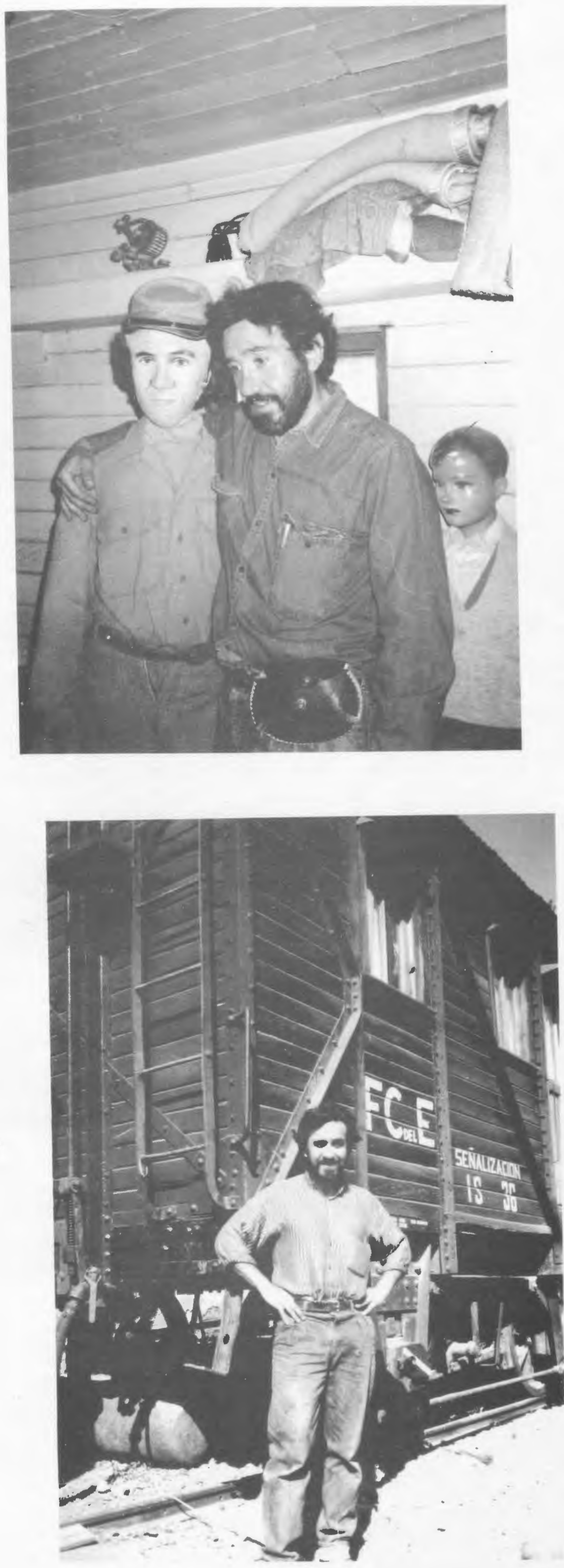
R.S.: Are they crazy about life?

P.T.: Yes, I think most of the people here are crazy about life, Even though I didn't know much about this place before, with my trains I just fitted in because people here are very open-minded and very special. In other places I might be considered a bit crazy. San Alfonso is not a big place. There are no more than a thousand people here. And there used to be a train that ran from San Alfonso to the mountains. Well I bought the land and then I started buying ties, sleepers and rails to lay some track. I was preparing the land for the trains that were coming here. A year after I laid the track I got my first caboose. After the caboose, another small caboose and then another smaller caboose. These are all standard gauge cars. Also I bought a small box car, with a narrow two foot gauge. I have two different types of track: standard and very narrow gage. Ever since 1985 I have been restoring these cars because I bought them as scrap metal and they needed considerable repair. Inside and outside. I've been using the same paint scheme, lettering, and numbering as the old cars used to have. Three years ago I decided to build my own steam engine, a scale model (on a scale of one to eight). A live steam engine. I went to California to buy blue prints and some small parts that I needed and from that I got started and have been working on it ever since in my spare time. I still have to spend time preparing the big cars. In two years I hope to have my live steam engine and cars running along the land here.

R.S.: Tell me about you, the person, who also writes poetry.

P.T.: Yes, I write poetry. I ought to speak about myself. By profession I am a scientist but ever since I was a kid I was attracted by the arts: music, painting, sculpture. When I made the decision to go to university, my parents advised me not to go to the Faculty of Arts because I couldn't make a living out of it. Probably they were right. That depends. But I used to make sketches, drawings of people, caricatures, cartoons. And that has helped me a lot in the work I am doing now because when you are restoring something you have to have some sensitivity to what you're doing: using colours and all that, and for me it's a way of relaxing, writing poetry, painting. I paint trains, but now I'm painting other things. I started writing poetry three years ago and published my first book in 1990 with other people from San Alfonso who work together in a poetry workshop. I write poems about trains. I have one called "Cosmic Train."

R.S.: Tell me how you formed La Asociacion Chilena de Conservacion del Patrimonio Ferroviario.

P.T.: The Chilean Association for the Conservation of the Railroads was formed when I started this hobby collecting big trains in 1985. I was one of the founders. Its main objective is to stop the scrapping of historically valuable trains, cars, and steam locomotives. In the last ten years all these things have been disappearing in Chile: ten years ago there were probably a thousand steam locomotives, now there are less than a hundred, and the few that are left are going to disappear. The Association started with about forty members, now we are about one hundred. We meet once a month. We have achieved goals. We've stopped the scrapping. It's ridiculous. In the U.S. they are buying trains from other countries for tourism and we are destroying ours for scrap iron. That's happening in most countries. They are trying to recover the engines but it's too late. In Chile most of our trains were built in America, Japan, and Germany, but several, about twenty, were built in Chilean workshops before the turn of the century. Completely built in Valparaiso and San Bernardo. But somehow that capacity disappeared. I don't know why.

R.S.: What other poems have you written to trains?

P.T.: I have one called "To the Saltpeter Trains": those are the nitrate trains that disappeared in the 1920 's. In the north of Chile where the nitrate mines were, there were many trains, most of them British, serving the mines. The mines had to close down in the great restructuring of the economy in the 1920's, because they couldn't compete with the price of materials being produced in Germany. It's a very nostalgic poem about the nitrate trains. About five years ago I went on a tourist train that travelled all the way to Copiapo and saw all the empty stations in the desert and the abandoned mines.

R.S.: You came back to Chile in 1978. You lived here under the dictatorship. How was your life? Were you involved in politics?

P.T.: Fortunately I haven't been involved in politics, otherwise I would have been in very deep trouble. But being a scientist wasn't very pleasant. My university was under the control of the army. We had rectors from the military and many military people inside the university and there was no freedom of speech or anything like that.

R.S.: How is your life now? How do you see the change in government from dictatorship to democracy affecting it?

P.T.: Pinochet had some success with the economy. Aylwin's govemment is trying to preserve Pinochet's line on the economy. But I've been reading sone statistics about the poverty level in Chile and even though the economy is stable and inflation is low, people are still very poor. Per capita income is very low. There are more people with money now, but if you take the average, we are doing worse than any country in Latin America. There is a lot of unemployment which is not reflected in the statistics. The other thing I've noticed is that Chile is trying to copy a typical capitalistic country. We have been bombarded for fifteen years with propaganda on the television to consume, to buy and buy and buy, and that causes people to have a lot of false expectations. If you are poor in Chile and you turn on the TV, you see all these good things that you might buy but you cannot afford. Having a good economy does not necessarily mean a good quality of life. The quality of health and education in this country is very poor now. The country is running well for a minority. If you belong to that minority you cannot complain. We are going to go through the same stages as other countries. We are devastating our nature, our forests, because people want to make money fast. They are planning to build huge dams in the south, which will mean that some cultures, some Indians that live there, will disappear completely. So more money doesn't necessarily mean a better life. I also think
Chilean people are becoming more egoistic now. People used to be very generous but they're under more pressure to produce, to compete, and they become more self-centred.

R.S.: And how is life in San Alfonso?

P.T.: San Alfonso is a little oasis. If you live in Santiago and come to San Alfonso, you see a completely different attitude towards life. People are more relaxed, more friendly, they share a lot.

R.S.: Do people know each other here?

P.T.: Yes, after six years, I know practically everybody. I still sense that community feeling I used to have in Talca. Everybody shares everything tools. You go to a neighbour and ask for a hammer or saw. In Santiago you cannot go to a neighbour and ask for a saw.

R.S.: They'd kill you. With the hammer

P.T. More money means more crime. My feeling is that producing more money in a country spoils the quality of life; there has to be a balance. Consumerism produces false needs. Not everyone needs a colour TV. Having a colour TV doesn't necessarily improve your life. Quality of life is more love, more sharing, more culture, more literature.

R.S.: Part of your association with trains, with the preservation of trains, also involves consciousness about life and values?

P.T.: Yes, because for me, for

example, an old train car is not valuable because of the metal it contains. It is valuable because somebody built it a hundred years ago, and it was used and people travelled in it Its value is not the metal that can be scrapped and turned into hammers. Looking only it. Its value is not the me something is wrong. It is like destroying the pyramids to take the at the immediate use of something is wrong. It is like destroying the pyramids to take the blocks of stone out of them because you could build a bridge. That s ridiculous. A lot of things disappeared completely in the last twenty years because there was no trams in Santiago. The trolleys about preserving things. For example we had trolleys and trams in Santiago. The trolleys were dismantled and now with the pollution problems in Santiago they're putting the trolleys back. But it was obvious twenty years ago that we were going to have a pollution problem. There's not a single tram in the museum here. We are not ver

You don't see things in our museums like in the museums in

R.S.: So what are you plans for the trains in your backyard? P.T.: At present they're only a private collection but I would like to share my collection with more people. In the future I would like to have some sort of museum that would tell you the story of the trains. I don't like the idea of a dead museum: trains siting there and people watching them, but something that would tell you about the people that lived inside, what they did. Railroad people were like sailors. There were a lot of stories and things happening in trains. Freight trains, passenger trains -- there were all kinds of trains. There were battles, killings and strikes on trains. People don't know about it in Chile. R.S.: You could publish a book about trains.

P.T. Well, there are more talented people writing the history on trains but I can pick up some stories and put them in poems and novels.

R.S.: Will you open your house for people then?

P.T. I might open my house, but it will take time. There's a lot of restoring still to do and I would like to have some small $\mathrm{HO}$ models on display, showing how a train works actually. Not just for kids to look at. But I'm not talking about the technical thing because acture the technical side but rather the history and not a bolts. A lot of fanatics are only interested in the stories: the people, not the nuts an .- after all I'm building a steam engine -- but I think mechanics. I know how trains work -- after all I'm building a steam engine -- but I think the stories of the people are because people built them.

R.S.: Can you tell me one of the stories of when your father took you to the station in Talca when you were a child? Can you remember one of those days? 


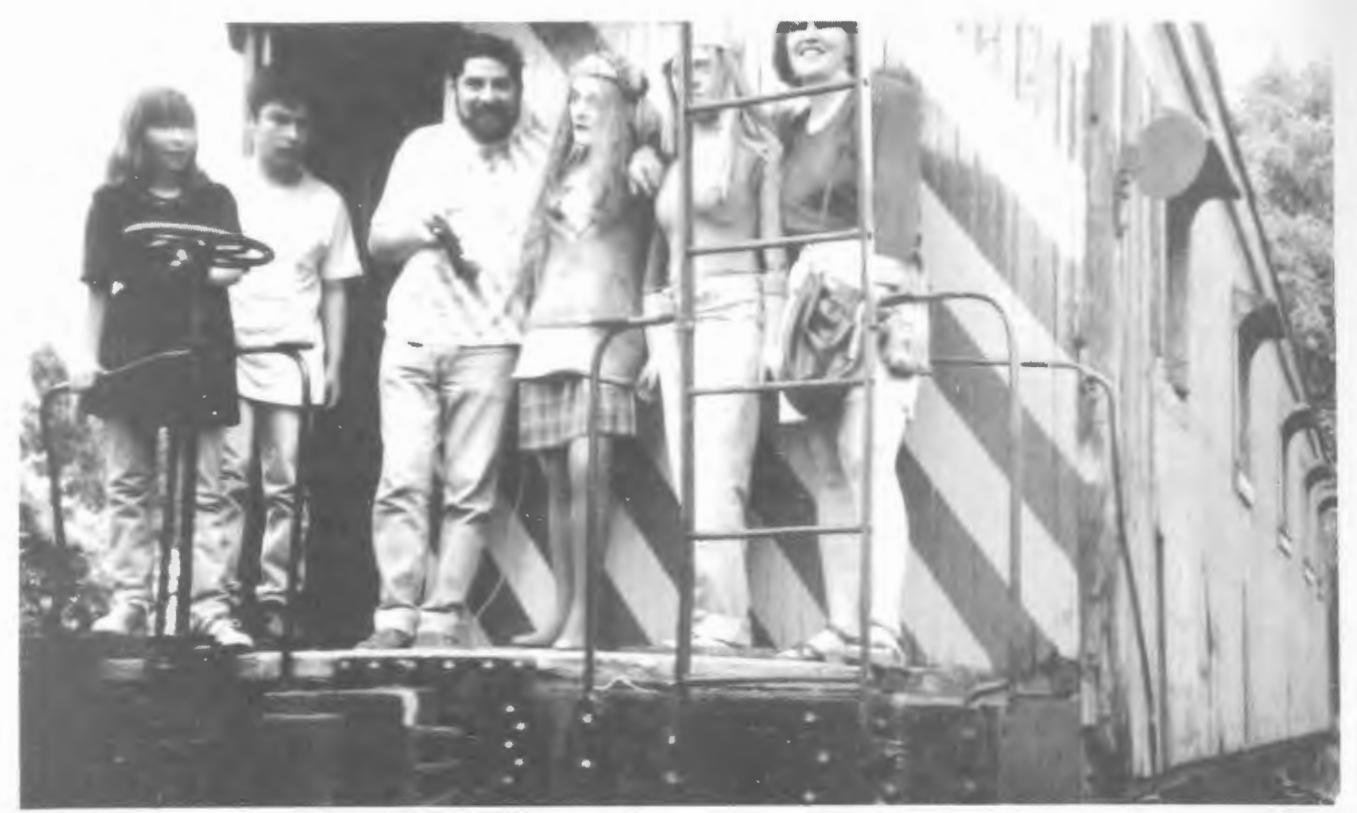

P.T.: I don't remember how old I was, perhaps six or eight. I remember when the steam engine passed by, the wheels were so huge, several times my size, that I was amazed about the size of the engine that could actually move them. When the train passed the ground shook. When I grew older, I used to escape from school with friends and wander around the yards watching the steam engines going back and forth. However, I was not technically minded then. I didn't keep track of the numbers of the trains, which is a shame. Sometimes you need that information to track down a special train, for example, the train that pulled a president after an earthquake. There are engines and cars that have stories about them. If you have the numbers you can locate the records.

R.S.: Yes, they used to use trains in presidential campaigns.

P.T.: There were huge steam trains going south pulling twenty cars.

R.S.: Lets talk about your family. Are you married?

P.T.: I am married and have two children. I am married to Tilly Roberts. She came to Chile from England in 1972. I think having an English wife helps. She is more flexible. I know a few friends who would like to have something like this, they could afford it, but their wives wouldn't tolerate it. The British are known for being interested in all sorts of engines. They like trains a lot. There are a few British gentlemen in our association.

R.S.: So being married to a Brit helps?

P.T.: It didn't interfere and it helped. Our association is headed by a British man.

R.S.: If someone gave you a job on a train, what would you like to be?

P.T.: I'd like to drive the engine. I wouldn't want to be an administrator in an office.

R.S.: And who would be your crew?

P.T.: Friends. I have a carpenter here who has been helping me. He has become interested in trains and I think I would take him along as a stoker. His name is Jorge Meza Nanko. $\mathrm{He}$ is from the south. He lives in a caboose here. He has his own caboose. I think I'll take him along as an assistant.

R.S.: But you need more crew to operate the train

P.T.: I would like to take people from San Alfonso and have a party on a train. Jorge is a good cook. Some Japanese or Chinese are talking of putting the train back here for tourists. I've taken steam trains south and the atmosphere is very good. People bring guitars and wine. Like in the old days. This is gone in the new trains which are very quiet, like planes, and very boring. In Europe the trans-European express, the one that featured old films, disappeared, and now an entrepreneur has restored it and it is a luxury line. That tells you that people like such things. Sleeping in your small compartment, it's like being in a hotel with an atmosphere that can't be recreated through any other means of travel. You can play cards. People seldom play cards on a plane. But on trains... R.S.: Do you think you are stuck in another era?

P.T.: Yes. I don't like the modern idea of speed, and living fast. You don't enjoy life.

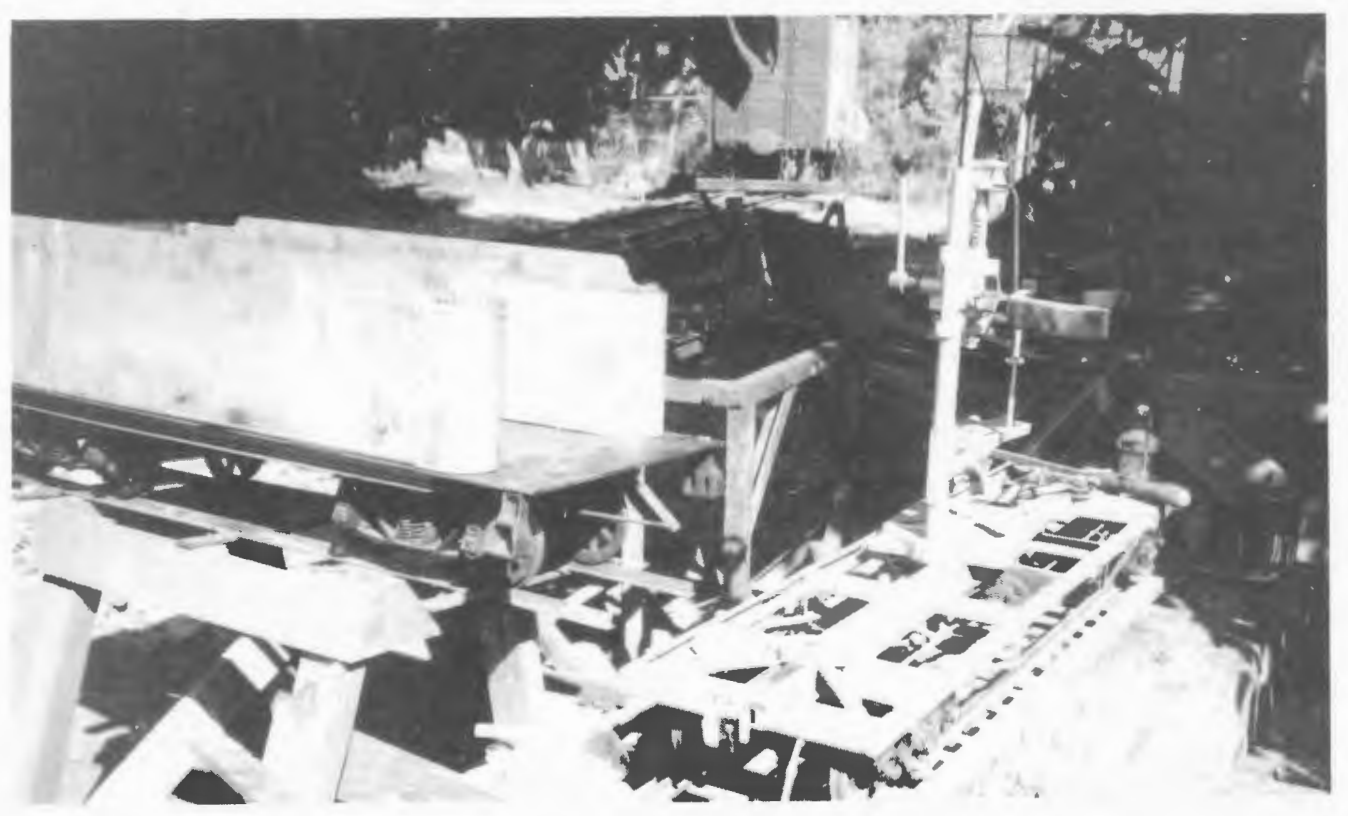

Miss Algrave

\author{
by Clarice Lispector \\ translated by Alexis Levitin \\ selected by James Gray \\ edited by Karl Jirgens
}

Brazilian writer Clarice Lispector's (1922-1977) first collection of short stories Lacos de Familia was published in 1960 . The book included her story, "The Crime of the Mathematics Professor" which appeared in anthologies such as Modern Brazilian Short Stories (William L. Grossman, ed., Univ. S. Calif. Press, 1967). Her other writings include Algun Contos, 1952; her novel, The Apple in the Dark (Knopf), and her more recent Passion according to G.H. -- Lispector has been described as a "spiritual" writer with great stylistic integrity. Rampike is greatly pleased to offer Alexis Levitin's translation of Lispector's "Miss Algrave."

She was subject to criticism. Therefore she didn't tell anything to anyone. If she had spoken, they wouldn't have believed her, because they didn't believe in reality. But she, living in London, where ghosts dwell in dark alleys, knew for sure.

Her day on Friday was the same as any other. It only happened Saturday night. But on Friday she did everything as usual. Yet a terrible memory tormented her: when she was little, about seven years old, she had played house with her cousin Jack; in grandpa's big bed they both had done everything they could to have little children, but without success. She had never seen Jack again, nor had she wanted to. If she was guilty, so was he.

Single, of course, a virgin, of course. She lived alone in a small penthouse in Soho. That day she had done her grocery shopping: vegetables and fruits. For to eat meat she considered a sin.

When she passed through Picadilly Circus and saw the women waiting on street corners for men, she all but vomited. Even worse -- for money! It was too much to take. And that statue of Eros, up there, so indecent.

After lunch she went to work: she was a perfect typist. Her boss never looked her over, and he treated her, fortunately, with respect, calling her Miss Algrave. Her first name was Ruth. She was of Irish descent. A redhead, she wore her hair in a severe knot at the back of her neck. She had a lot of freckles and skin so fair and delicate it seemed of white silk. Her eyelashes were also red. She was a pretty woman.

She was very proud of her figure: generously built and tall. But no one had ever touched her breasts.

She usually dined at an inexpensive restaurant there in Soho.

She ate spaghetti with tomato sauce. And she had never entered a pub: the smell of alcohol nauseated her whenever she passed such a place. She felt offended by humanity.

She raised red geraniums which were a glory in springtime. Her father had been a protestant minister, and her mother was still living in Dublin with a married son. Her brother was married to a real slut named Tootsie.

Once in a while, Miss Algrave would write a letter of protest to The Times. And they would publish it. She would note her name with much pleasure: "Sincerely, Ruth Algrave."

She took a bath just once a week, on Saturday. In order not to see her body naked, she would leave on her panties and bra.

The day it happened was a Saturday, so she didn't have to go to work. She got up very early and had some Jasmine tea. Then she prayed. Then she went out for some fresh air.

Near the Hotel Savoy she was almost run over. If this had happened and she had died, it would have been awful, for nothing would have happened to her that night.

She went to a choir rehearsal. She had a melodious voice. Yes, she was a privileged person.

Afterwards, she went to dinner and allowed herself to order shrimp: it was so good it even seemed a sin.

Then she made her way to Hyde Park and sat down on the grass. She had brought along a Bible to read. But -- may God forgive her -- the sun was so insidious, so good, so hot, that she read nothing, but just remained seated on the ground without the courage to lie down. She tried not to look at the couples that were kissing and caressing, shamelessly, without a care for the eyes of others.

She went home, watered the geraniums, and took a bath. Then she went to visit Mrs. Cabot, who was 97 years old. She brought her a piece of raisin cake and they drank tea. Miss Algrave felt very happy, and yet... And yet.

At seven o'clock she returned home. She had nothing to do. So, she started knitting a sweater for winter. A splendid colour: yellow like the sun.

Before going to sleep, she had some more jasmine tea with biscuits, brushed her teeth, changed her clothes, and tucked into her bed next to the sheer white curtains that she had stitched and hung herself.

It was May. The curtains billowed in the breeze of this singular night. Why singular? She did not know.

She read a bit in the morning paper and then turned off the lamp at the head of her bed. Through the open window she saw moonlight. It was the night of a full moon.

She sighed a great deal because it was difficult to live alone. Solitude crushed her. It was terrible not to have a soul to speak to. She was the loneliest creature she knew Even Mrs. Cabot had a cat. Ruth Algrave didn't have any pet at all. Pets were too bestial for her taste. She didn't have a television either, for two reasons: she couldn't afford one, 
and she didn't wish to sit watching the immoralities that appeared on the T.V. On Mrs. Cabot's television she had seen a man kissing a woman on the mouth. And this without any mention of the transmission of germs. Oh, she if she could, she would write a stern letter of protest to The Times every day. But it didn't seem to do any good to protest, or so it seemed. Shamelessness was in the air. She had even observed a dog with a bitch. She had been much struck by it. But, if God wished it so, then so be it. But, she reflected, no one would ever touch her. She continued to endure her solitude.

Even children were immoral. They were to be avoided. And she greatly regretted having been born out of the incontinence of her father and mother. She was ashamed at their lack of shame.

Because she left grains of rice at her window, pigeons would visit. Sometimes they entered the room. They were sent by God. Innocent. Cooing. But it was almost immoral, that cooing, though less so than seeing an almost naked woman on television. Tomorrow, without fail, she was going to write a letter protesting the evil ways of that accursed city, London! She had once seen a line of addicts outside a pharmacy waiting for their turn for a shot. How could the Queen condone this? A mystery. She would write another letter denouncing the Queen herself. She wrote well; without any grammatical errors, and typed the letters on the typewriter at the office when she had free time. Mr. Clairson, her boss, highly praised her published letters. He said that she might become a writer, some day. She was proud and grateful.

That's how she was lying in bed, with her solitude. However, it was then that it happened. She felt that something that wasn't a pigeon had come in through the window. She was afraid. She called out:

"Who is it?"

And the answer came in the form of a breeze:

"I am an I."

"Who are you?" she asked, trembling...

"I have come from Saturn -- to love you..."

"But I see nobody!" she cried.

"What matters is that you can feel me..."

And she really did feel him. She felt an electric shiver.

"What is your name?" she asked in fear.

"It hardly matters..."

"But I want to say your name!"

"Call me Ixtlan."

Theirs was an understanding in Sanskrit. His cool lizard touch gave her goose-flesh. Ixtlan's head was crowned with interlacing snakes tamed by the prospect of imminent death. The cape covering his body was of worn purple, low-grade gold and coagulated amaranth.

He said; "Get undressed."

She removed her nightgown. The moon rose huge within the room. Ixtlan was small, white. He lay beside her on the metal bed and placed his hands upon her breasts. Black roses. The sensation was strange, too good. She feared it might end. It was as though a cripple had tossed his cane into the air.

She sighed and spoke to Ixtlan:

"I love you, darling, my love!"

And -- yes, it happened, she didn't want it to end, ever. How good it was, good God. She wanted, more and more and more. She breathed, "Take me!" and "I offer myself to you..." It was the triumph of the here and now.

She asked; "When will you come back?"

Ixtlan answered: "At the next full moon."

"But I can't wait that long!"

"That's how it is," he replied, almost coolly.

"Will $I$ be expecting a baby?"

"No."

"But I'll die from missing you! What can I do?"

"Get used to it."

He arose, kissed her forehead chastely and departed through the window.

She sobbed softly. She was a sad violin without a bow. The proof that all this had really happened was the blood-stained sheet. She kept it without washing it, so she could show it to anyone who might not believe her.

She watched the new day dawn, all in pink. In the fog, the first little birds began sweetly chirping, not yet stirred to a commotion.

God illuminated her body.

But, like the Baroness Von Blich, nostaigically reclining on the satin dossal of her bed, she pretended to ring the bell to call the butler, who would bring coffee, hot and strong, very strong.

She loved him and waited ardently for the next full moon. She didn't wish to bathe for fear of washing away the taste of Ixtlan. With him it was not sin, it was delight. She no longer wished to write letters of protest: she protested no longer.

And she no longer went to Church. She felt fulfilled. She had, a husband.

So, on Sunday, at the dinner hour, she ate filet mignon with potato puree. The rare meat, slightly bloody, was excellent. She drank red Italian wine. She felt privileged. She had been chosen by a being from Saturn.

She had asked him why he had chosen her. He had said it was because she was a redhead and a virgin. She felt bestial. She no longer found animals repulsive. Those who loved one another represented the best the world had to offer. And she waited for Ixtlan. He would return: "I know it, I know it, I know it.." she thought. She lost her revulsion for couples in Hyde Park. She knew their feelings.

How good it was, to be alive. How good it was it eat bloody rare meat. To drink tart Italian wine that contracted the tongue with its bitterness.

She was no longer recommended for minors under eighteen. She delighted in this, rejoiced.

As it was, on Sunday she attended her choir practice. She sang with more vigour than ever, and was not surprised when she was chosen the soloist. She sang her than ever, and wallelujah! Hal-le-lujah! Hal-le-lu-jah!"

Later, she went to Hyde Park and lay down on the warm grass opening her legs Lermit entry to the sun. Being a woman was something superb. Only a woman could understand. But she wondered; "could it be that I'll have to pay a high price woman could understand pay all that she had to pay. She had for my happiness?" She didn't worry. She would pay all that she had to "Ixtlan! Come always paid and always been unhappy. And now unhappin

quickly! I can't wait any longer! Come! Come! Come!" She wondered: "could it be he likes me because I am a bit cross-eyed? At the next full moon she would ask him. If it were true, she had no doubt, it would force her hand and she would make herself completely cross-eyed. Ixtlan,

to do, I'll do. Only I'm dying of longing. Come back my love. Yes. But, she did something that was a betrayal. All the same, understand and forgive her. After all, one had to do what one could, no? It happened as follows: unable to stand it any longer, she walked over to Picadilly Circus and approached a long-haired young man. She took him up to her room. She told him he didn't have to pay. But he insisted and, before going off, left an entire She told him he didn the night table. In fact, she needed the money. She became furious, one pound note on the night table. In fact, she ne showed him, almost under his nose, hower, whe laughed at her.

On Monday morning she made up her mind: she wouldn't work any longer as typist, she had other gifts. Mr. Clairson could go to hell. She was going to take to the

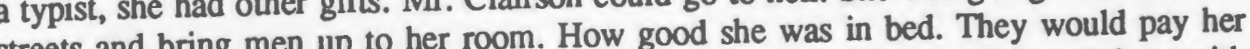
streets and bring men up to he dalian wine daily. She wanted to buy a bright red dress with excellently. She would drink Italian wine daily. She wanted hair down so that it was a beauty of redness. She was a wolf's howl.

She had learned that she was very valuable. If Mr. Clairson, that hypocrite, She had learned on working for him, it would be in quite a different way.

wanted her to go on working for him, it would be in quite a different way.

First she would buy herself a low-cut red dress and then go to the office, arriving, on purpo say to her boss:

"Enough of that typing! And you, don't give me your phoney manners, you fraud. You want to learn something? Go to bed with me, you fatuous twerp. And while you're at it, give me a hike in salary -- you old skinflint!"

She was certain that he would accept. He was married to a pale, insignifican woman, Joan, and had an anaemic daughter, Lucy. "He'll enjoy himself with me, that old son-of-a-bitch!"

And when the full moon arrived -- she would bathe, and purify herself of all those men, and prepare to feast, with Ixtlan.

\section{INSIDE YOUR CAVERNS \\ Translated by Cola Franzen from: Trampantojos: Ediciones Alfaguara, Madrid. by Saúl Yurkievich}

...loaded down with dreadful visions, with rancorous visitants,

irrepressible, the stampede erupts inside your contrite brain, ball of lava, anguish expands its imperious empire, besieges you and devastates you, pitiless, cuts you down, wipes out all bonanzas, all luck revokes and with its shadowy retinue implants itself, sovereign-like, penetrates your caverns, whelms the boiling cauldron, kindles the fires of fear, buries you in them, wretched, looses over you the devouring cohorts and whatever wounds, whatever lacerates, suddenly, hidden tumult, your turbulent turbidity drowns you, your wits turn into crab-infested quagmire, your mind is millstone, mortifying mortar, dying opens up penitent and your wreckage flies by, your infernal carnival, your parade of scarecrows that choke the life out of you, embitter your flesh, sting you, covered with slime you linger in this hour of râles, never ending, last gasp black and searing...

A morning sunbeam penetrates the blind, pierces the heart of your vampire.

So long, monsters, see you tomorrow. 


\section{IN RECENT YEARS: RAYMOND SOUSTER}

\section{an interview with preface by Carole A. Turner}

In November of 1995, Raymond Souster was honoured by being awarded the Order of Canada. Ray Souster has always had a concern for the future of Canadian literature and particularly Canadian poetry. One of Souster's aims as founder and editor of the "little magazines," Direction (1943-46), Contact (1952-54) and Combustion (1957-60), was to nurture new Canadian talent by introducing it next to more established writers from Canada and the United States. The most important and influential of the three magazines was Contact, which served well as an alternative to the progressively conservative Northern Review operated in Montreal by his friend, John Sutherland. Souster offered a vehicle for unconventional or experimental literary expression that was North American in tone, and as such, a rejection of British or European models. Also, the magazines worked well as a forum for his own poetry and his own open-minded views as expressed in the format of the magazine and in the editorials. Souster's periodical publishing went beyond the support of emerging Canadian talent. Souster also published what reads like a who's who of contemporary American (U.S.), authors. Issue number four of Direction was devoted entirely to Henry Miller. In his autobiographical essay "Getting On With It", Souster points out that it was in this issue that Miller's Tropic of Cancer made its North American debut (Contemporary Authors Autobiography Series, 311). Issues of Contact included poems by Kenneth Patchen, Charles Olson, Paul Blackburn, Robert Creeley and Cid Corman. In Combustion he published Gregory Corso, Robert Duncan, Theodore Enslin, Lawrence Ferlinghetti, Allen Ginsberg and LeRoi Jones (see also: Contemporary Authors Autobiographic Series, 314-15).

Souster made a name for himself as a publisher and anthologist when, in 1952, he co-founded Contact Press with fellow poets Louis Dudek and Irving Layton. Contact Press was a forerunner in the history of small press publishing in Canada, a precursor to the many small but successful presses today, among them Anansi, Black Moss, Borealis, Coach House, Dundurn, Oberon, Porcepic, Porcupine's Quill, Talonbooks, Turnstone and Vehicule, to name just a few. The mandate for Contact press was in keeping with Souster's preference for new poetry that was experimental and free from the restrictions of the lyric form. The press gave talented young writers the opportunity to get their work into print, many of whom were unable to get their work published by mainstream houses such as Ryerson Press or MacMillan. Among some of the Canadian writers to be published by Contact Press, in either books of their own or anthologies such as New Wave Canada, were Margaret Atwood, Margaret Avison, George Bowering, Victor Coleman, Frank Davey, David Dawson, Gerry Gilbert, George Jonas, George Johnston, D.G. Jones, Barry Lord, Roy MacSkimming, Jay Macpherson, David McFadden, bp Nichol, Michael Ondaatje, P.K. Page, W.W.E. Ross, Miriam Waddington and Fred Wah. Souster's influence as a publisher established a new precedent in Canadian small press publishing.

Raymond Souster's recent writing frequently displays a self-conscious awareness of the relationship between poet and poetic form. In earlier writing, Souster tried to maintain a more detached perspective, but now he has moved to a relatively engaged position. The "I" in his earlier writing adhered to modernist conventions featuring an imagined persona distinct from the author. However, in his recent life-writing Souster adopts a more post-modern sense of the "I" in which the author and narrator are apparently synonymous. There is a reduction in the differentiation between the life of the authorial self and life as depicted in the text. Further, because Souster chooses to confine himself to a poetic form, a second kind of breakdown or blurring occurs on the level of genre. A number of theoretical complications emerge as a result of Souster's shift from the more conventional modernist lyric form towards his recent life-writing prose-poems. Among these complications is the position of the reader in respect to the text. In this interview, Ray Souster speaks of his life, his writing and his audience [Edit. C.A.Turner]. **** *** ****

CT: In recent years the focus of your poetry has moved from what could be called social realism or social commentary to what could be called autobiographical fiction or life writing. With the exception of "T.O. Blues," Riding the Long Black Horse is autobiographical. Why the shift in focus?

RS: Well, I guess I've always written autobiographical poems... You've read that essay that I did, that ten thousand word thing ["Getting On With It" (autobiographical essay) Contemporary Authors: Autobiographical Series, Vol. 11. Detroit: Gale Research Inc., 1991 -- Ed. CT], and I guess that had something to do with it, and my father's death I wrote that sort of long anecdotal poem which is part fantasy and everything else. I guess I'm just moving in that direction.

CT: I noticed that in your earlier poetry you wrote mostly in the third person, and when one writes autobiographical fiction one normally writes in the first person, so it seems as if you are now writing pretty exclusively in the first person.

RS: Well, I guess that is true to a certain extent. You're familiar with Robert Lowell's Life Studies?

CT: Yes.

RS: Well I guess that's when I first got interested in that kind of poem. I don't think that mine are confessional so much, although they are to some extent.

CT: Is the "I" of the narration, or the first person narrator always Ray Souster, or is the capital "I" sometimes someone other than yourself?

RS: Well if it is, I usually make it quite clear. I usually use quotes to indicate someone talking. I've used that in historical poems and so on.

CT: So, if you are writing in the first person, it is from your perspective. The first person narrator is not some character that you've created for example.

RS: Yes, for instance in the poem, "Little Mac" where I am writing about MacKenzie.. there is somebody talking about him or sometimes he's talking. So I there's a change or shift there. I've just finished a long anecdotal poem about the old Colonial tavern on Yonge Street. I don't know if you've ever heard of it.

CT: Down at the foot of Yonge street?

RS: Yes, it's down opposite the Eaton's department store, the old Eaton's. It used to be the Shoales Hotel in the early days, then in 1950 it became a Jazz Bar \& Grill. It became very famous during the fifties because they had bands like Duke Ellington's, all the top people, and this continued almost to the seventies. And then the jazz policy came to an end around 1970 with the Beatles and Rock and Roll. Then they had a Rock 'n Roll policy there and the thing gradually fizzled out, then it was closed down and then finally torn down two or three years ago. So, I started writing the poem ten years ago but I ended up finishing it last Fall. But its anecdotal and I bring my friends into it and so on. CT: I was wondering whether the last two collections, Old Bank Notes and Riding the Long Black Horse have been a natural progression for you and have in some ways prepared you for writing a traditional or conventional autobiography?

RS: Well, I guess that's true. I have plans for future poems that will be quite different though. Right now they are just in my head you know. One of them is a long poem about Toronto. I've been thinking about it for a number of years. I just have to get a form, something to hang it on, it's quite a problem. Like William Carlos Williams' Paterson, you know the various devices that he used. Well, I have to get something. He uses the Falls and so on. Anyway, that's the problem I have to solve there and then decide what shape it will take. That's one future project that may never get written [laughs].

CT: Many critics have said that it is impossible to capture the self on paper because there is always a gap or discrepancy between the writer's self and what is presented on paper. What difficulties have you had in presenting yourself and your experiences on paper? RS: Well, I haven't done any deep analysis of myself, that's been pretty surface. I've been more my interested in my interaction with other people. I think I am more interested in situations and in the drama that surrounds ordinary events.

CT: Many academics are concerned with how writers construct the self. However, many writers are not as concerned with the construction of the self or self-reflexivity. Many write intuitively rather than rationally.

RS: Yes, think so. I've mentioned Robert Lowell and I guess some other confessional writers like Anne Sexton. Anne Sexton has gone quite deeply into the psyche That kind of poetry really doesn't interest me. I can stand Lowell because there's a balance. He doesn't intrude too much into the poem. If he is writing about himself in the prison for example (when he was arrested he spent a year in prison), he is writing about the characters that are in prison with him and he is more interested in them than in himself. As you were saying, my early work was more objective, I was sort of the onlooker and rather than writing about being involved, I was sort of like a Flaubert that's writing in the wings or a Henry James watching his characters perform.

CT: In your earlier writing you were more like the quiet observer and now it seems as though you are foregrounded or more out front in your poetry.

RS: I think I've tried to be more honest, not as cool. I've always been charged with being too sentimental, but I've never worried about that. Some people may think this latest work is further along that line. I haven't had any reviews yet, so I don't know. I get so few reviews anyway and most of them are meaningless, it's like writing into a vacuum really. There's no feedback and so on. I'm making up about 4 or 5 copies of this poem about the Colonial and I'm sending to people I went to the Colonial with, like Bob Fulford, and I want them to check up on the accuracy of what I'm writing about, but also any other comments they have. I'm interested in getting some feedback on whether the poem succeeded. I don't think that it's that successful but it's the best I felt I could do. It is obviously a place that meant quite a lot to me. I never went there that often, but it was a treat to go there. But. I really couldn't afford it anytime during my banking days for instance. Not that it was that expensive it was just out of my range, so any time I did go I really treasured it. I went there with A.J.M. Smith one night and Pee Wee Russell was playing and I didn't know that Art Smith was a really big Dixieland Jazz fan, you know. We had a wonderful evening together.

CT: I can imagine. As you know, the memory is very selective and we choose to write about some things and choose not to write about other things...

RS: Oh Yeah!

CT: Sometimes we're conscious of leaving things out and sometimes we're not. Do you strive for accuracy or truth in your poems or do you not care about truth because all writing is subjective and representational anyway?

RS: Well, I try to be true about the events as I remember my reactions to them and so on. I guess you can get a certain degree of accuracy in it. I wouldn't want to invent anything. I've sort of gone the other way. Michael Macklin who is a pretty severe critic of my work (he's X'ed a lot of poems that I've submitted in my different collections because he thought there was too much self-pity or other things), he said people have a certain image of you, and we don't want them to see that side of you. So a poem would get X'ed. I can usually agree with about $95 \%$ of his decisions. He's probably saved me from a lot of clinkers. He's my editor at Oberon [Press, Ottawa]. He makes suggestions and he's very good. We work pretty well together and pretty loosely. He's got a system, I don't know how other author's do it. I know several who gave up on him and left Oberon. He sets all my books by hand and he uses the machine with hot lead to make the 
type. He goes along... he takes the manuscript to my poems and he'll correct it as he puts it into type and so when I get the proofs this has been changed and that has been changed. If I don't like it I can put the original back but usually the changes are so good that I usually go along with it This is disconcerting to a lot of people, they don't want their work changed. I can tell you a story about uh... who's that author, that novelist in New Brunswick who writes about the Miramichi?

CT: David Adams Richards.

RS: Yes, Richards submitted his first novel to Michael and Michael set it up in type and used that system where he makes changes as he goes along. So when Richards got the book back he wrote back and said "change everything back to just the way I had it." And Michael had to start all over again.

CT: Well publishing houses are so structured, so controlled these days. It's good that you're with a smaller press and that you can work so closely with them.

RS: Yeah, it has its advantages, and of course I've been publishing almost every year, book after book. And that's just not happening now with anybody, even if they had the work ready. Maybe some of the smaller presses can manage it, like Coach House, but McClelland \& Stewart are very stingy about poetry books, and it's getting worse as you can tell by what's coming out. Sorry to digress, what else?

CT: I've noticed that the reading public and even the viewing public, if you want to talk about television has become so voyeuristic As a poet who writes on a very personal level sometimes, how does this make you feel, does it change the way you write?

RS: Well it doesn't bother me because nobody is very interested publicly in my work and nobody's writing about it, so I can just go ahead and do what I want and nobody bothers me. But I see the trend of interviews now, and the writers encourage that too. Maybe they should stand off a little more, but most writers like an audience and the like being on stage and in the limelight. That's part of being an author for a lot of people. A big part. CT: When you write do you imagine an audience or do you write for yourself?

RS: For myself (for my enjoyment), and for a handful of people that I keep in mind, four or five people. I correspond loosely with about four or five poets across Canada. They're in my age range and they know where I'm coming from. That's the problem when you are still writing in your 70's, your points of reference are different. What interests you may have happened in the 50's or during World War II. And the younger people who might be your audience today weren't even around then. This Colonial poem... how many people, who are around today, have even heard of the place?

CT: Well, when I was reading your poetry I began to feel connected to the Toronto of the past, the good old days when things were simpler. You write about the west-end of Toronto, the Humber River, Jane Street loop, Lakeshore Boulevard, and downtown too, Bay and College Street and so on. You write about places in Toronto that I'm too young to remember, but you write about them so authentically and movingly...

RS: Well, I hope you will be moved to look back and find out about the past.

CT: Right, through your poetry, I feel part of those things too.

RS: I guess I have a very strong sense of Toronto and this country. That isn't too fashionable these days either. Well, everything is negative and you can't blame the younger generation for being negative because they haven't got that much going for them. If they're going to do anything they've got to do it by the seat of their pants. They aren't going to get much help from anyone. It's a tough world. My world was an ordered world where you worked at the bank and nobody thought of getting fired unless you were laid off or stole some money or did some unthinkable thing. All of that has changed.

CT: Toronto is getting larger and larger, and more diversified culturally and ethnically, and because of this there is no sense of a unified community that shares common values and beliefs, so I think that the emphasis on the individual in society, and on individual writers as opposed to a community or school of writers is the result of the changing dynamics of the city and of the country.

RS: Yes, I think so. I guess there are some communities that still feel it, that sense of community, like the Beaches. But it gets harder all of the time. That's the problem for the country and for the future. Maybe all races could come together and maybe race won't matter in another 50 years. And we're still a city and so on. And maybe more intermarrying, that's the hope for the future. I don't know how valid that is. This British tradition, it's pretty much dead. I think some of the values survive. But there are new laws. Whether we like it or not. We envy the United States in a lot of ways, but we bock at joining them or taking on some of their characteristics. They're gradually wearing us down. Americans are very nice people, they are very friendly. At least I've felt that as individuals, but as a mass they react differently. I guess the whole country was born out of violence and they have never shaken that. They had their Civil War which proved nothing and they still haven't gotten over that I think. And here we've been going along quietly just making constitutional changes. The biggest event was the comic opera of William Lyon MacKenzie and Louis-Joseph Papineau. An event like burning the parliament buildings in Quebec City was one of the biggest events in our past. But there is no history of real violence.

CT: I suppose that the FLQ Crisis is probably one of the biggest events.

RS: Yes, but that was largely artificially created. I think the Quebec government had a shaky hold on things so they thought if they instated the war measures act they could throw the ringleaders and intellectuals in jail. I guess it worked. The independent Quebec that we see today was bom then. I don't know what's going to happen there.

CT: Do you ever look at your writing as historical documentation or historical fiction? When I read your poetry I think about how revealing it could be to those younger than yourself in regard to connecting them to the past.

RS: I think that's what I want to do. I'm enthusiastic about it and I try to convey this in my poetry. We have events in our past that are lively and worthwhile. A lot of people sacrificed a lot to bring us to where we are.

\section{Overheard in Tiananmen Square by Ray Souster}

\author{
"These hundreds of workers \\ in the Square today, \\ why do they labour \\ so long and so hard?"
}

"It's merely one phase or our routine maintenance of the Square, so necessary to keep unspoilt this jewel of our city."

"Some men with scrubbing brushes appear to be trying to remove a big patch of blood etched into the pavement."

"I'm afraid your eyes deceive you. The students who held rallies here this past week made many signs and banners, and no doubt some careless boy or girl

missed with their over-busy spraying or overturned a can of paint; then with youthful bravado left their calling card for all to see."

"Can you comment on the fact that the hospitals are bursting with wounded and dying, students, workers, even children-was there any violence here?"

"It cannot be too highly emphasized that although our troops were stoned, then even fire-bombed by hoodlums, with many young counter-revolutionaries

even threatening the use of arms, officers of our glorious Red Army showing amazing restraint, gave no orders to the troops to fire."

"Some observers couldn't help but notice several great mounds of student corpses horribly intermingled with their bicycles, their school books, their blankets."

"Sir, the darkness and confusion in the Square played tricks with both eyes and cameras; what you speak of were innocent students huddled tightly together to keep warm,

with many of them dozing off so peacefully that a casual observer in the dim light might easily have mistaken them for the faces of the holy dead."

[On June 4th 1989 an estimated 3000 demonstrators were killed in Tiananmen Square -- Ed.]. 


\section{XXX}

\section{by Andra Nieburga \\ Translated by Banuta Rubess, Edited by Karl Jirgens}

Andra Neiburga is an active writer living in Riga, Latvia. Her work has rarely been published in English. Rampike is pleased to offer Banuta Rubess's translation of Neiburga's apocalyptic text "XXX."

Time doesn't fly, it storms. The future's dusted with yesterday's ashes. Insane musical notes deny melody, colour belies form. Paper-thin people shuffle past one another, the earth itself is flat. The screen's dimensions, a shadow play.

Paper dolls squall for liberty and smother in shrouds of flags.

FAITH, HOPE, LOVE

Fate. Pain. Indifference.

Moscow teenagers play inside elevator shafts permitting the cabins to smear them against the walls, in Lima they ride the train tops ducking electrical lines. Flights of passion, intoxicating falls. Mothers give birth in the attics of abandoned houses, claw holes in sawdust for their stillborn.

Black children, stomachs distended with hunger, yellow children torn by bullets, white children beneath the treads of tanks.

You are slain for your nationality, you slain are for your faith, you slain are for a cigarette.

AND THE EARTH WAS WITHOUT FORM, AND VOID

A stone thrown toward heaven always returns to earth, a dying man -- a child's mind.

Tears and blood are physiological fluids. Thousands of troops march in ant tracks, crossing the earth in an imagined order. A hydrocephalitic homonculus fingers holes in the sky and, with idiot giggling toys with rockets. Homo ludens _-. imbecile civilized senility.

THE EARTH COUGHS BLOOD

Throughout the centuries, book pyres bum, human pyres burn, but holyday illuminations are the brightest of these fires. Humanity's discreet charm, with a crocodile purse on the road to nowhere. Babylon, mother of harlots, dances on the last night, gyrating her naked ass while chewing gum, the hearts of nations melt like tin in her neon-dazzling eyes.

IN THE BEGINNING WAS THE WORD

Millions bray for the Word, but know it not; whosoever remembers the Word will be Christ. But, "Father, if thou be willing, remove this cup from me: nevertheless not my will, but thine, be done." Father kills Son and from that hour, the blood of sacrifice blossoms on our lips, murder is justified in the name of a cause.

DUST STORMS, ASH STORMS, SOUL STORMS

The last Chinese emperor weeps in Stalin's death camp, neither Allah nor Mohammed came to aid the Kurds, Fortune [Laima] wanders Latvia empty-handed. The sky, an oilstained rag, and in flight there, the souls of dead birds. Wells burn, Wormwood* falls, and the third part of the waters are made bitter, the sun a sackcloth of hair (ashes permeate your eyes, your mouth -- inferno: the mother of order -- in moonlight bounds Anubis, the hound of darkness, over fields of white ash, this symphony of silence).

THOU SHALT NOT KILL

Moloch gorges on children, smacking his toothless gums. The Beast vomits his guts, and the jackals of humanity, the artists, whine as they tear at the smoking intestines. Alchemists turn gold into blood, idiots search for the Holy Grail, Christ has no wish to be sacrificed again, the world shakes at the sound of red laughter**.

Snow never melts in the eye-sockets of the dead. Slaughter is the mother of order. KNOCK AND IT SHALL BE OPENED

Flies buzz Babel's lap, milk sours in mothers' breasts, masses howl for narcotics, Bread, Booze, Liberty! I fear the highways and the black forests, the subway and the submarine, electricity and fire, but the planets dance in endless harmony, supernova conflagrations are merely notes in a cosmic overture.

The earth is void and formless.

THOSE THAT HAVE EARS, LET THEM HEAR.

* Wormwood, La-anah in Hebrew, Absinthos in Greek, Chernobyl in Russian; the star that is predicted to fall in the Book of Revelations 8:11 at the opening of the seventh seal (following the trumpet of the third of four angels) resulting in the poisoning of one-third of the earth's waters.

** "red laughter" a reference to a Leonid Andreyev's novel Red Laughter (1904), and an allusion to a quotation from that book; "When the world has lost her mind, she starts to laugh like this. Surely you know the world has lost her mind. All the flowers and songs are gone, the world has become round, smooth and red, like a skinned head."

\section{Latvian Photography:}

The Age of Glasnost \& After

featuring the works of:

Gvido Kajons \& Valts Kleins

assembled by Vid Inglevics

The following are photographs taken by two noted Latvian photographers in the days The the withdrawal of Soviet forces from the Baltic states. These photos were prior to the withdrate magazine by the well-known Toronto photographer Vid Inglevics.

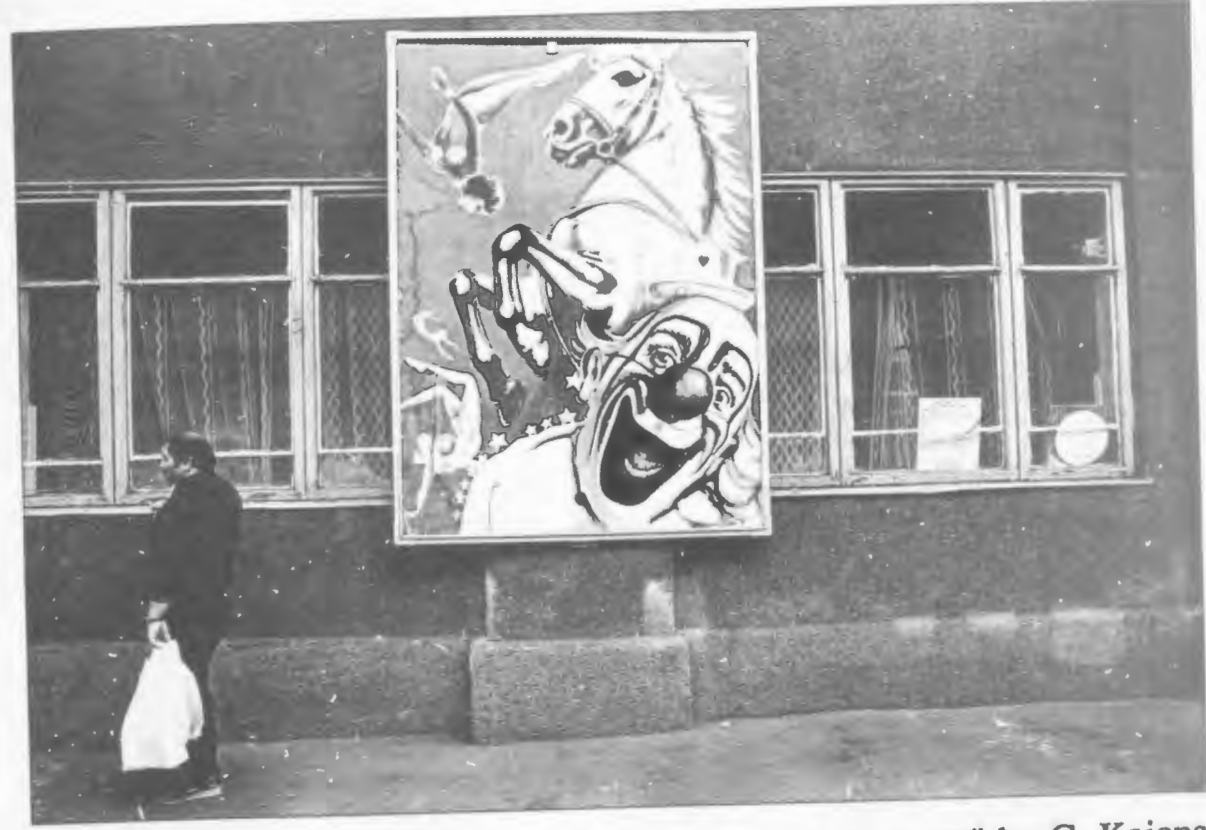

"The circus is in town" by G. Kajons

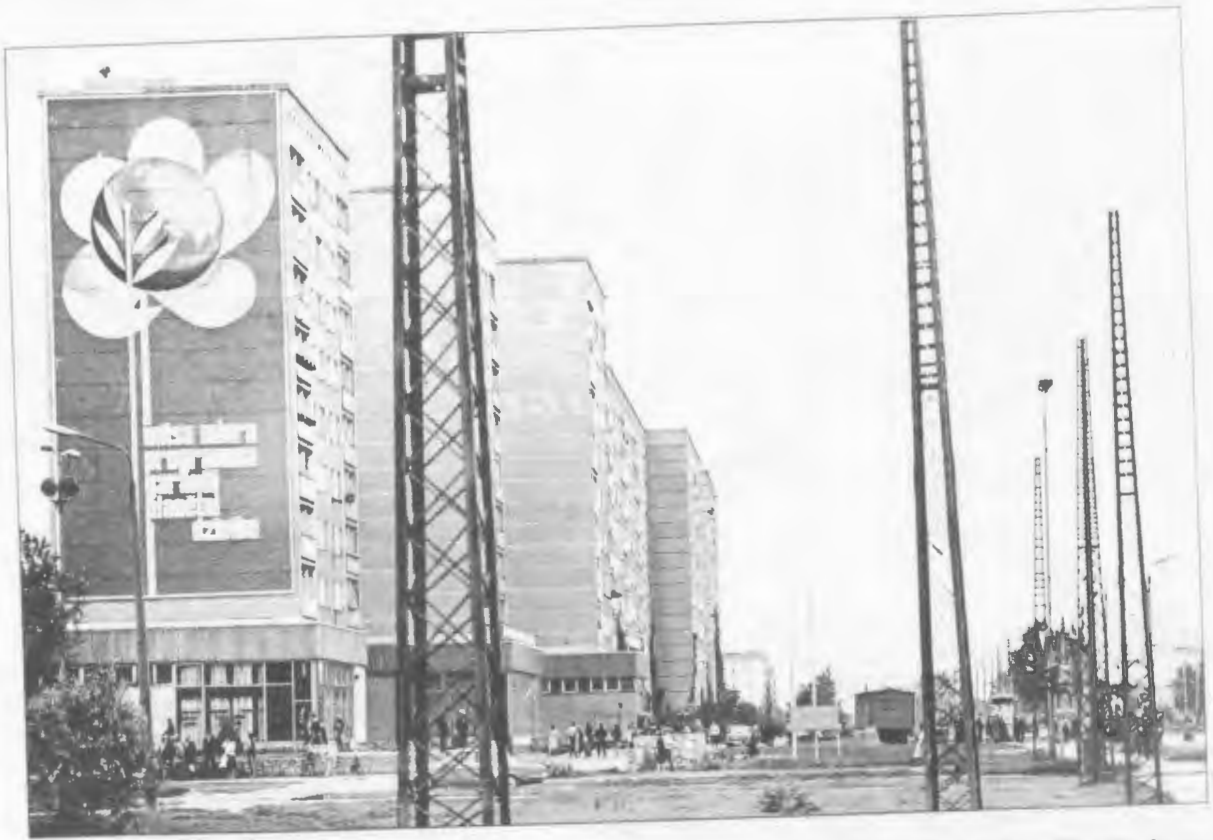

"Our peace program guarantees global prosperity" by G. Kajons

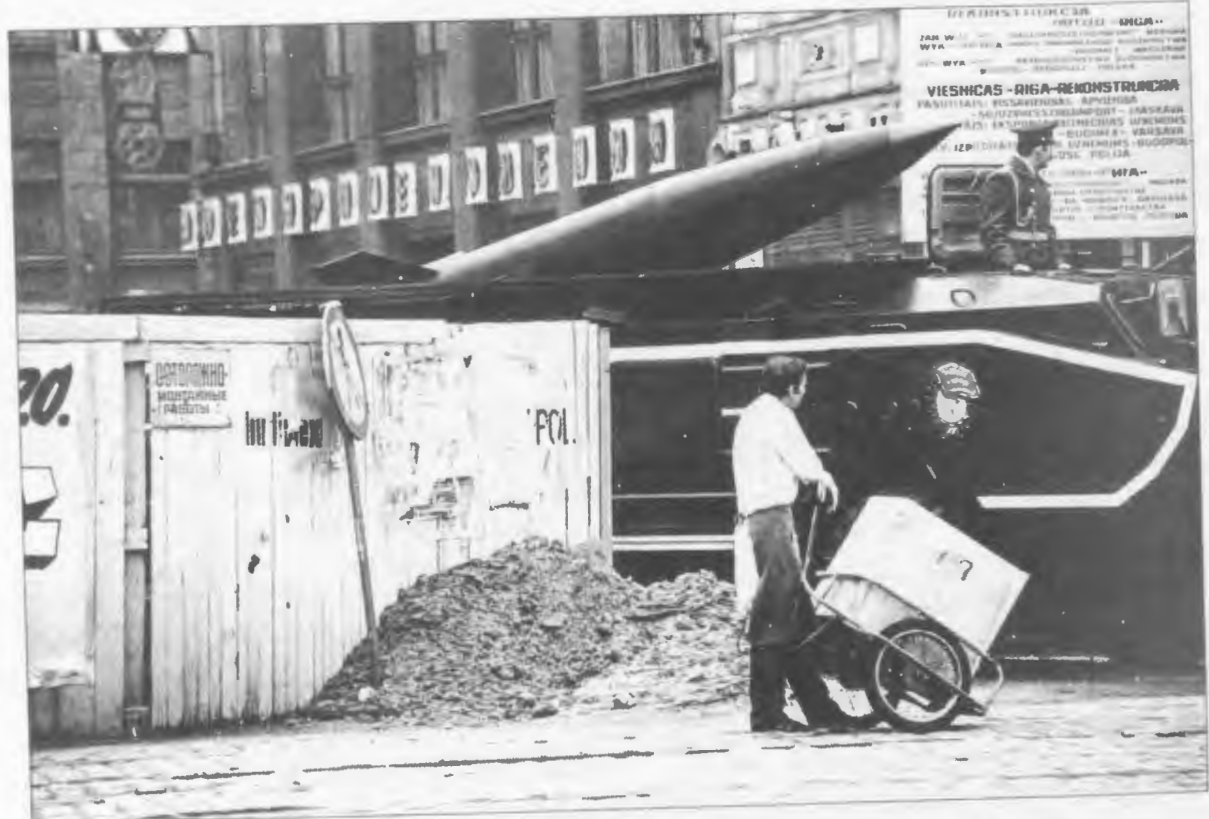

"Reconstruction in Riga" by G. Kajons 


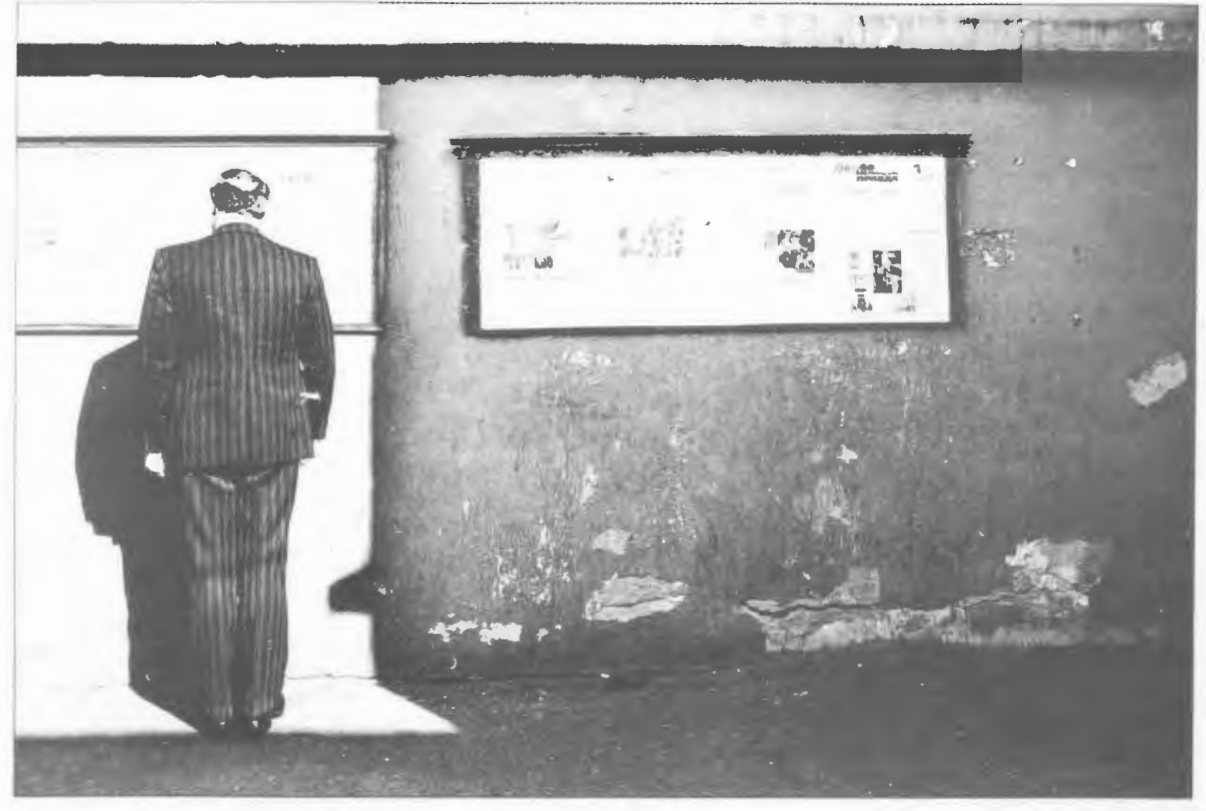

"Today's News" by G. Kajons

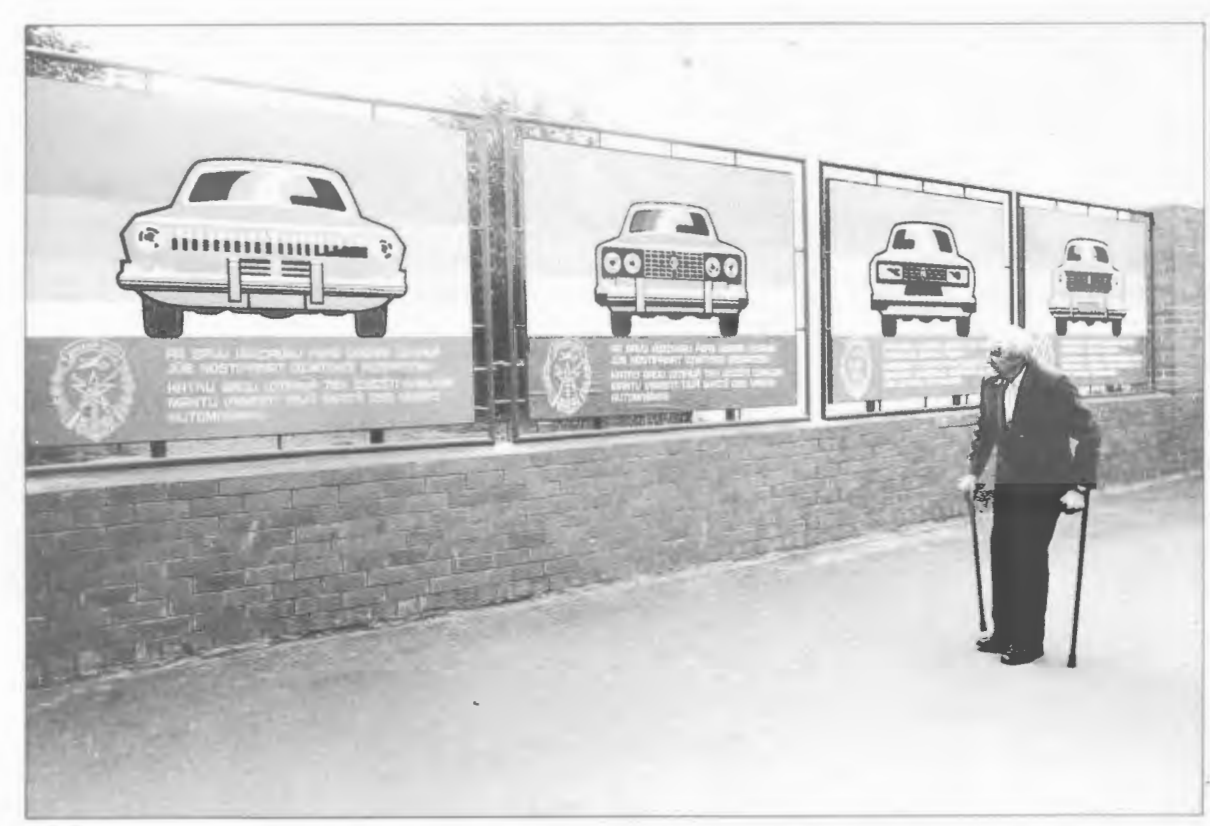

"Your lottery dollars help strengthen the nation" by G. Kajons

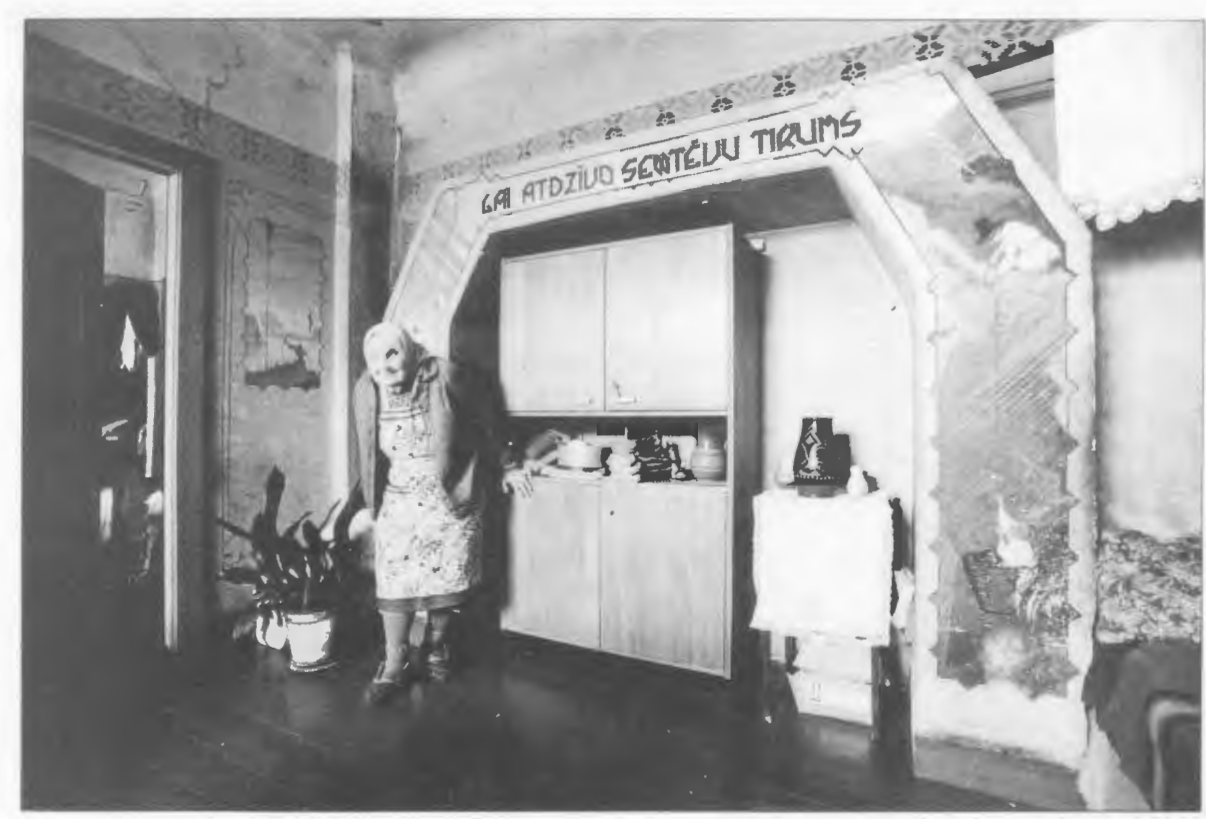

"Let us return to our ancient roots" by G. Kajons

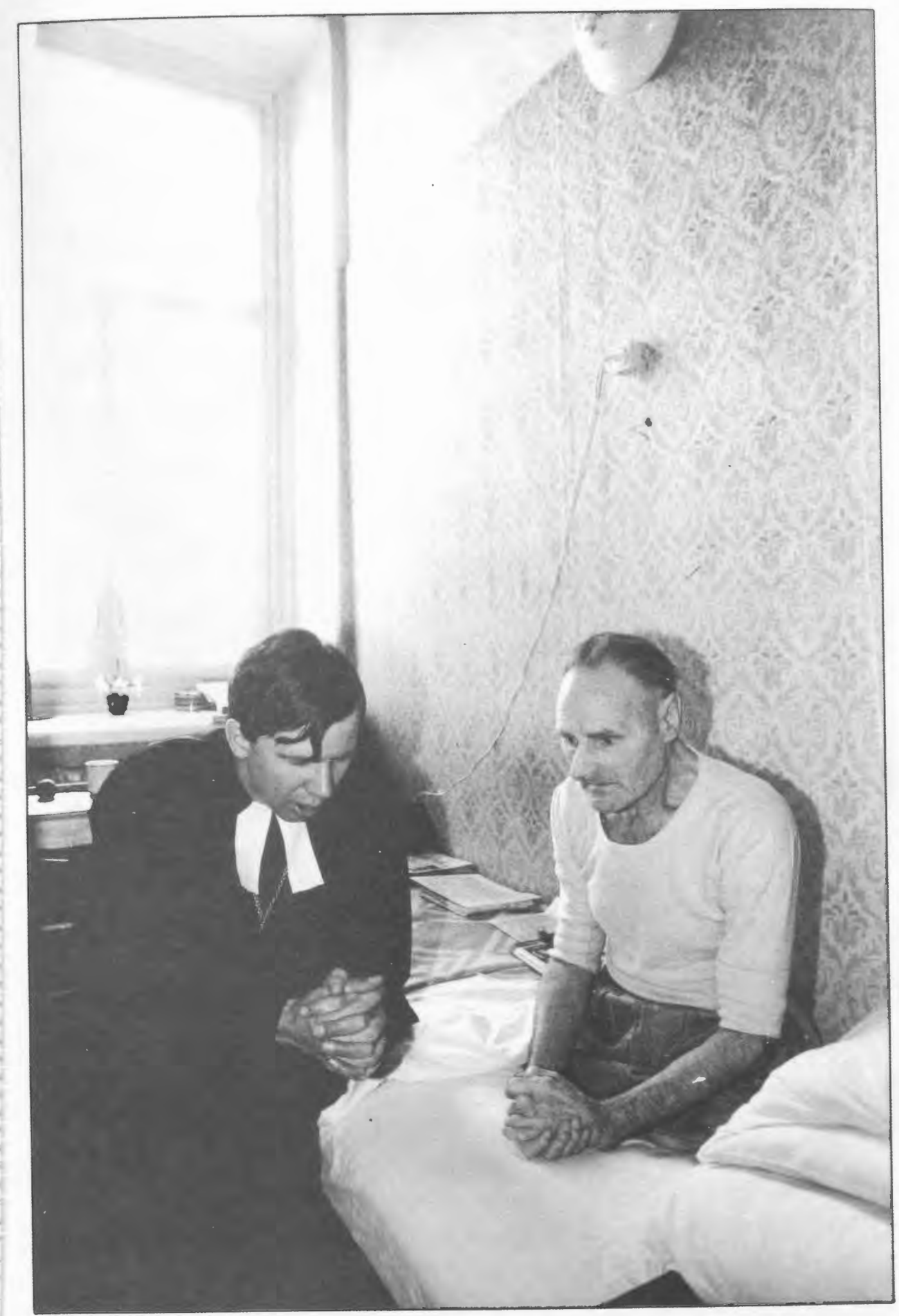

"Solace in prayer" by G. Kajons

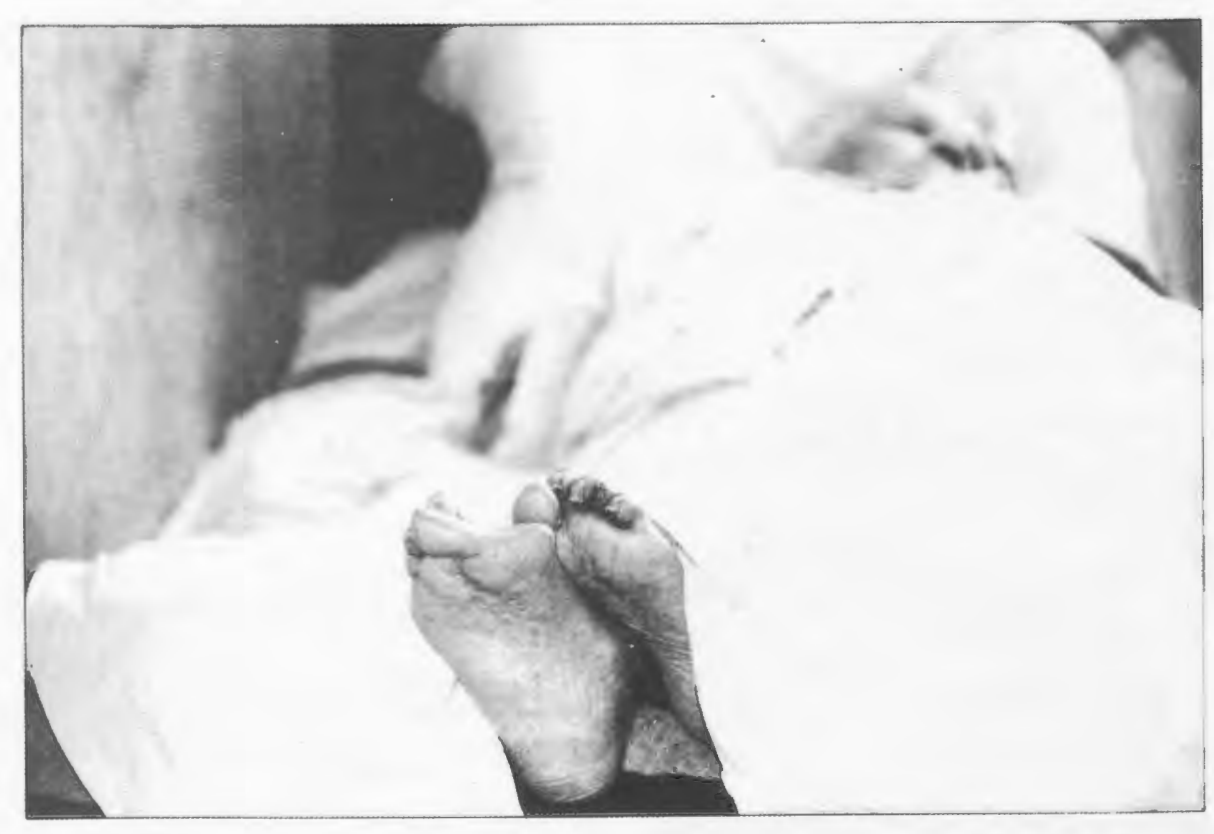

"Old age" by G. Kajons 


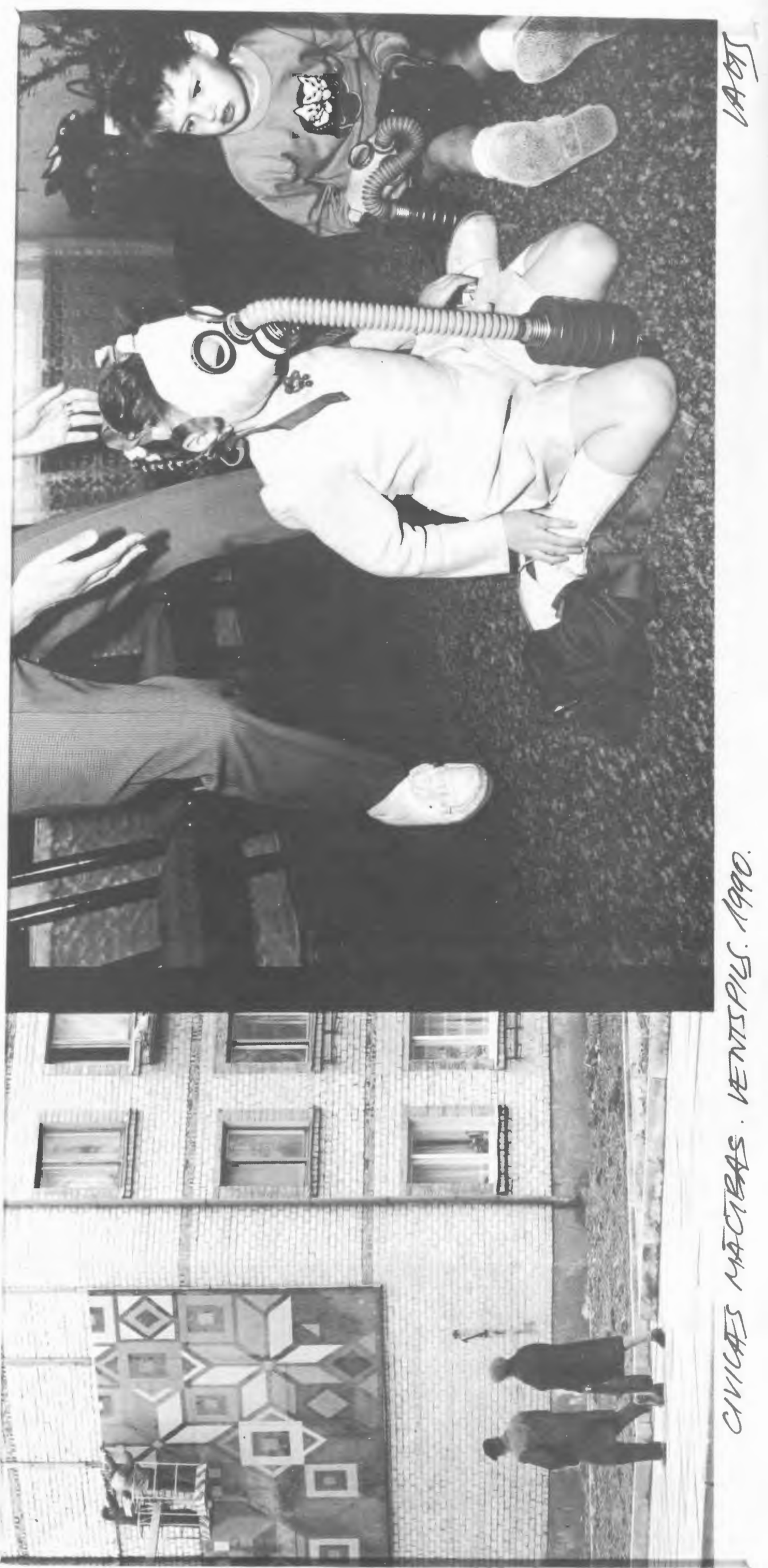

"Civic Instruction" by V. Kleins

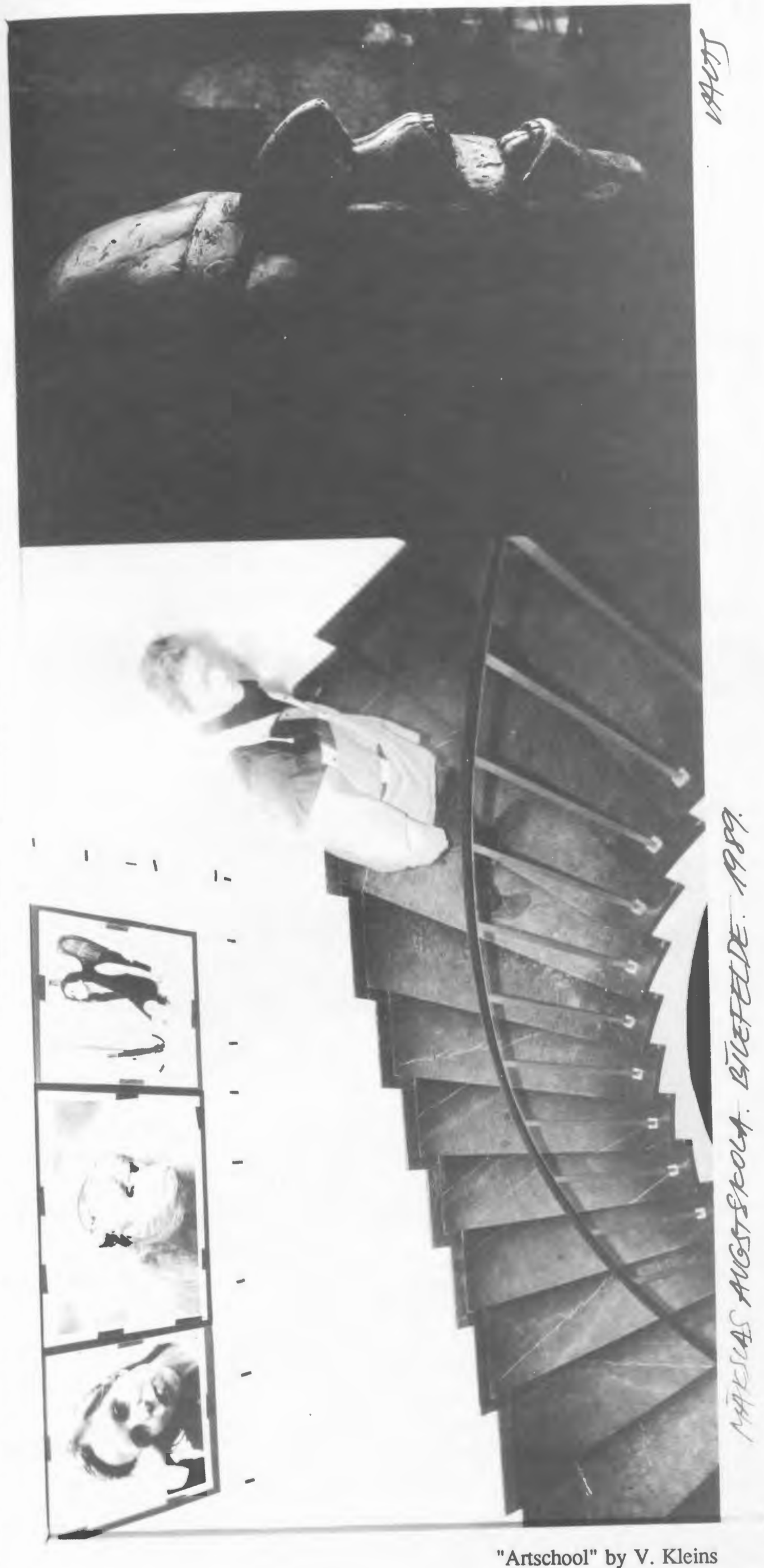




\section{Excerpt from:}

\section{THE SIBERIA BOOK}

\section{by Aleksandrs Pelecis translated with prefatory note by Karlis Edwards Jirgens}

Author Alexanders Pelecis spent twenty-five years in the Soviet Gulag, living a hero's life, though not by choice. For Pelecis, as for Solzhenitsyn, the world as he knew it ended suddenly one day. Shortly after the publication of a poem came a knock at the door, and he was arrested, tried and sentenced to the distant Gulag for literary crimes against the state. Several years after his release, I wrote to him and he responded with kindness, asking only that his words be spread, so that his promise to the dead could be partly fulfilled. He died shortly after in October of 1995. These words are part of a series of translations from his journal: Sibirijas Gramata [The Siberia Book: Latviesu Preses Biedriba: 1993. Available in Latvian in the USA -- Library of Congress Card \#92-74960]:

Upon departure I am stripped of all save the clothes I wear and even these are stripped of zippers, buttons. Save one. The fellow working at the prison in Riga, chose to be generous that day, and left one button on the trouser front, a small act of kindness that freed both of my hands, and so, perhaps saved my life. A week on the train amid piss and shit and others that stink and fear as much as I. The first time behind the wire barbs is instructive. I am asked to fetch some wood that has been pre-cut. It seems simple, almost thoughtful, until my little crew is taken to a pile of timbers in the blackfly woods. Each $\log$, is just heavy enough to require the full strength of three men, the timbers to be carried on shoulder across a mile or two of tundra and muskeg, an imbalance or stumble causes the $\log$ to fall, and precious calories are spent upon raising it up again to shoulder height. I notice that some men must hold their trousers up with their hands, the buttons, zippers, belts have all been removed. The value of a belt is beyond comprehension. Strings or safety pins are highly marketable items. I watch the others struggle. I feel an idiot joy for my single button. Food, is offered at a subsistence level, and eventually all will die from malnutrition, unless they learn to adapt quickly. Gruel the daily food. "Sundays," I ask, "what happens on Sundays? Do we have a day of rest?" The guard laughs, "Of course, on Sundays, the task is much lighter, no logs to carry then." I endure until the end of the week, when I learn the task is now to bury bodies. Three stiffs to a grave, to save time in digging and wood in the making of markers. The earth is rock hard, the shovel ineffectual. The guard is heavy and armed with a sub-machine gun and metal teeth. He laughingly gives me what they call the "pencil," a rod of steel with sharpened point for hacking the permafrost. This work turns out to be harder and sadder than the daily routine, by Sunday noon we look forward to hauling timbers.

There is a black market here, as in other places, and so, to survive, I approach the King of Thieves. The bargain is simple. I trade my jacket for paper and pencil. Such paper! The remnants of a Portland cement bag imported from the United States. Still, with its many layers it serves well, and the pencil, more of a stubb than anything, nonetheless it serves, although I annoy the minor theives with constant borrowings of a pocketknife to sharpen it. My letters are small brown squares folded diagonally and with some extra services I offer, I can sometimes get stamps. These letters, sending and asking love, request food, money, some other aid, are sent to my wife, who by now is living with another man. He complains at the letters arriving "postage due" and threatens to return them unopened if I can not have the courtesy, in future, to pay the proper postal rates. Though much is sacrificed for my mailing I have gained little. With time, the stub has worn out, the paper gone. Resolving not to die entirely forgotten, I write to the stars. We are permitted to rest after seven at night, our barracks little more than strap-wood shacks with chinks as wide as a finger. The wind howls through, the wood in the stove makes a small difference. In the fall, survivors, now grown wise collect moss and grasses to stuff the cracks. The "beds" are filthy cloth bags stuffed with straw, thrown across slats of wood. The slats are few and far between, many pirated for the stove, but the ground itself is too cold for sleep. The bags and straw are rich in fleas and bugs. On dark winter mornings I awaken unable to raise my face, not from exhaustion, but because my hair is frozen to the slats. Here there are others to share the starvation, scurvy, betrayal, comuption among guards, the mercilessness, frost and snow squalls, wolves and bears. Mad or rabid foxes attack children and adults alike, rats chew children's fingers off in the night, flocks of ravens and buzzards darken the sky waiting for those that collapse among those too weak to dig graves. Even the odd eagle helps to contribute to sanitation of conditions by eating the dead or near-dead. Black flies and malaria carrying mosquitoes, gadflies, hornets, and locusts during the spring, summer and autumn. People are stung so that eyes swell up, flesh burns as if on fire. Bluebottle flies create halos around the head, a parody of saints, there is no escape from fleas, or bedbugs. Jumping in the river doesn't help. We are eaten alive. Once we heated the inside of the barracks to 40 degrees celcius and ran outside, and heard all the bedbugs die screaming. Insects, a bane, can also be eaten. Swept up seven baskets of them from the floor. Perhaps, we could laugh a little about this.
During nights, I walk a short distance from the strap-wood hut and use my finger to write poems in the snow. Each morning on timber-detail, I would look at the ground, and by then the winds have obscured my words. It is my twenty-fifth year here and I have written volumes. I have written of my Czech friend with whom a I made a vow, that if one should live and the other die, then the living would tell of the dead. All the dead. I have written of the twenty million that have been imprisoned under Stalin, held in camps with names such as Vorkuta, Kolima, Inta, Taiseta. Of these, some thirteen million lay weneath the snow but I somehow survive, feel a strange guilt, wonder why I should live. Bure they are overlooked by United Nations inspectors as "tolerable" numbers of "madmen" "political dissidents" and "dangerous criminals." These dead, were the cream of the crop, the intelligentsia, those with direction, with culture, with common

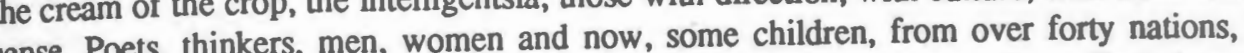
Kense. China, the US, England, the Baltic, Poland and Ukraine. Atheists, Jews, Christians, Korea, China, "he US, Enith my finger, Buddhists. A "United Nations" meeting in the gulag. At night I write with my finger, warm it in my mouth, frozen letter, line and poem by poem. My poems collect beneath the snow. This is the permafrost, even frozen wooly mammoths are found here, millions of years old with bits of green grass still in their mouths. Here, my poems can also be found. But am I the only one writing in snow? The Gulag is vast. Perhaps there are found. But am I the or in the summers, poets of sand, a requiem for the homeland here, a symphony there, and perhaps some blood poets. There where the flaming mortars charred their flesh, there, and peyond words, of blood and bone, hidden for now, but close to the surface. scratch beneath this snow and you'll find not only mammoths but voices that cannot be erased by snow or electric fences. These flames will not be snuffed $\alpha$ this flesh will be read.

For the past month I have been on latrine duty. The icy winter prohibits the usual venue. Outhouses with pits beneath them are useless. They are impossible to empty. Instead, the guards had us build privys some ten feet above ground. Mounds of layered and multi-coloured excrement collect and freeze solid. After a while the snow and ice polish them. We affectionally dubbed these frozen monoliths, "The Marbles of Bolshevism." I is our job to use the "pencils," the 2 metre crowbars to remove these columns. This evening we are dragged from our barracks. The wind is high, howling. Guards shove us rudely. Something is up. They assemble us in the compound, some are near collapse. We stand for an interminable time, the wind rips through us, our clothes flapping like the feathers of crows caught in a storm. The temperature is $-38^{\circ}$. There is a camp regulation that if it drops to $-40^{\circ}$, then we are relieved. Our feet paw the earth a camp regulation the bask the ball shoes from America could never have been meant The issue black canvas top basketball shoes from America could never have been meant for this. After a while the commissar addresses us with ambiguous questions, accusations. Here, I am your Czar and God! You will remain standing all night until someone confesses!" The crime remains un-named. We stand, unkowing. Some grin, some have trouble breathing, standing, lean against others. Finally, the guards haul forth a frozen figure under burlap. It is human. Another stiff. So what. But perhaps a murdered guard? Unthinkable. No point, only punishment for such things. They place it in front of us. Oddly it stands by itself. They pull the burlap off. A marble monolith, but re-shaped into a statue of the commissar, uniformed, complete with scar, patch over the eye, war medals on the chest. Quite excellent. In the heroic realist style. One arm akimbo, looking slightly upward. It looks like marble. Some begin to chuckle knowingly. Others catch on. The commissar starts swearing a blue streak, a machine-gun volley passes over our heads, but we can't stop laughing, our group is in disarray, some bending over with laughter. Some artist has expressed himself. We'll pay for this. But for now, we laugh. After several frozen hours, we are rudely returned to our barracks. Several have died waiting.

The winter wind is death. Nightmare visions keep repeating. Tanks approach the barracks locked from outside after curfew. Mortars open fire, screams from within soon crushed beneath the treads. Screaming voices in the night. Exterminations. This broken kaleidoscope. A broken symmetry, the spirit tom on multi-coloured shards of glass. On the day of the Constitutional Celebration amazement at music being played. Amid the the day of the Constitutional Celebration amazem, a young woman bursts out of the guardroom, scream on her lips, hair dishevelled, clothes torn, half-naked, throws herself onto the high voltage barbed wire, hangs there, body trembling under the charge long after, both hands frozen in a death grip, the smell of searing flesh. She hangs until daybreak. Cutting off the voltage also means shutting off the searchlights, and electricity to the fence. This can't be done. The fence is several kilometers long, there might be an opening. Tonight she hangs, electric Fatima waiting for day, waiting for the sun, the glass of the broken kaleidoscsope.

Alexander Pelecis (Alex Gray) was released after twenty-five years. With Stalin dead, the Gulag became more or less irrelevant. He was not informed of the imminent release. The authorities pressured him to sign a document pleading guilty to political dissidence and crimes against the state. He refused on the grounds that his only crime was to tell the truth through poetry. On the next day, he was shocked to receive his release papers. He learned shortly after, that all prisoners were to be turned free in any case. He was issued learned shortly after, that all prisoners were to be the train back to Riga, Latvia. Little remained of his original garments save the button that had been spared in a capricious moment [Ed. KJ]. 


\section{PURGE \& RECLINUS}

\section{from: The Once upon a Time Stories of Opal Louis Nations}

Once upon a time in a far distant land lay two villages spaced no more than a couple of miles apart. The villagers of Briskly worshipped the God Purge. Purge was the God of sprinting so the Briskers ran a lot and kept fairly healthy and trim. A system of tribute was worked out whereby all did their share of active praise once a day. Young children between the ages of four and ten ran between seven and eight every morning including weekends; youngsters between eleven and thirteen, between eight and nine a.m. Teens legged it between ten and eleven and young adults an hour thereafter so that all puffed and perspired in the name of Purge. Folks over thirty usually did an hour stint in the afternoon but this excluded senior citizens who were ascribed thirty minutes each day before tea time. Everyone ran on weekends which greatly troubled the folks of neighbouring Squatford who had to endure wave upon wave of sweaty bodies as they stomped and wheezed through their neighbourhood without rest during the daylight hours.

Now the villagers of Squatford worshipped an equally singular God. The Squatties' God was called Reclinus, and the people worshipped Reclinus by keeping with them at all times during the day a folding chair or seat. This meant that on the hour every hour, from sun-up to sundown, the Squatties would break out their chairs, seats, stools, couches, and recliners upon which for a period of ten minutes they would quietly sit cross-eyed and bolt upright in reverence to their almighty God -- Reclinus (later referred to as the patron saint of all couch potatoes). Sometimes Squatties would squat directly in the path of ongoing sweaty Briskers, and as was considered courtesy at this time, the Briskers would skirt around. Tension gradually increased. The Squatties were cheesed off with the constant thomp-thomp of feet and agonizing gasps for breath. The Briskers were niggled with having to run an obstacle course ever day.

The trouble started when Fred W. Dormant, a Squattie upholsterer, stuck out his foot just as an unsuspecting Brisker, one Percy Lint, a sweatband salesman, was jogging by. Down went Percy in the mud, his nose and knees covered in muck. Percy swore revenge, and that was how it all started. That evening Percy and his pals gathered in a secret meeting at one of the many giant sneaker and sweatsuit supermarkets. Almost all the working folk thereabouts were employed in the sportswear business. Late the next night, a bunch of Briskers broke into a Squattie furniture and upholstery warehouse and vandalized the place. Not a single stick of furniture survived. From then on it was outright war. Rows of cross-eyed Squatties blocked all roads and paths. Squads of Briskers formed raiding parties while others stayed at home indoors worshipping quietly on expensive pieces of Nordic Track. The regional economy slumped as factory warehouses and retail outlets burned to the ground. Out of work people were starving. Some were desperate and sought a peaceful resolution. During a brief truce Brisker and Squattie delegations met one evening on neutral turf and an agreement was drawn up. This lead to the construction of rickshaw factories all over the region. Both sets of villagers lived in peace again as contented, cross-eyed Squatties sat in rickshaw seats drawn by happy sweaty Briskers jogging all the while from Briskly to Squatford and back again.

\section{Bumbo, which is by Devon Eastland}

\section{seeing it all still}

tree-climbers, a native of the Moluccas; also: this tree, covered in dense rum colored fur sticky with buckwheat honey

having a body of raw sugar, boiled fromsweet vegetables and covered with slick reflecting scales in deep molasses brown and sometimes wearing a black cap and a ring around one eye composed of rum, sugar, water and nutmeg

stirring up a new batch of bumbo from the kitchen which is a drink that produces sweet vision of a nut brown complexion

Pleasant ground, sweet, black, rotten, and mellowed ware my bitter

bumbo's only sweet description

rum, sugar, water, nutmeg...

\section{a hard aromatic seed covered in} sweet stick viscid dunder a leafless fleshy stem furnished with pointed scales feeding chiefly on the larvae of bees and wasps and ideally sweet when drawn from late honey drunk by the potto or kinkajou's large lustrous yellow eyes and soft wooly yellowish brown fur

the bumbo is ready

\section{CODE 7}

\section{(excerpts from a novel in progress) by Robert Anderson}

In the apocalyptic language of time, desire voids the vanity of the word/ward. page/pain

列

Images of dry fingers touching sagging breasts. The mechanisms of eternity break down. Prom changes. The dream you embodiment reproductions void expressions ind the discursive
Toice burying you convoluted into absorption all these words random obscuring origins the signs are the metaphors. and and ferninine lips motivatic imagination, the neurological signal of the fiction... the manic drift to another time/space... no fear of conception... the death you left behind... bibliographic information on acid free paper.

Born in the past tens, torn through the spiral. When nothing's contained, nothing's left to destroy.

The angels are real in this dream, moving with precision, fingers wet to touch. Nameless ladies obscured from gravity the black hole where no sex breeds... pure thighs and ribbons in their curly hair.

Pain/dissolution.

On the returning. Meaning the past. Opaque eyes painted like a canvas with self.

here, naked soldiers in tents survive the dead revolution. Your strength texture, mine textual to evade narrative predestination/corpses without bones.

This purgatory makes girls anorexic. Throbbing flesh/prayin

mythology/living this sickness. Saints devouring their invisible selves.

The movie kiss.

I don't care if these walls covered in fingerprints are beige or off-white.

No experience exists outside this disfigured womb... ......

\section{XXX}

Waking up beside a red plastic suitcase at my bedside. In a hospital you try to make connections. Not like now. Images hypnotizing, hypothesizing, making light fall into a well and me the voyageur entering into a story I can't possibly write so I being to a well and mite it this Sunday a window in a coffee rewrite it this Sunday afternoon drinking Ethiopian coffee sitting at a wemories of dreams I could shop with a dalmatian dog lying beside me on the floor. Memories of dreams I could never have possibly dreamt. A faculty of the mind outside of mathematical language... no never have possibly dreamt. A faculty of the mine up dead and there's still no relief... seen from the window, a sign on the sidewalk:

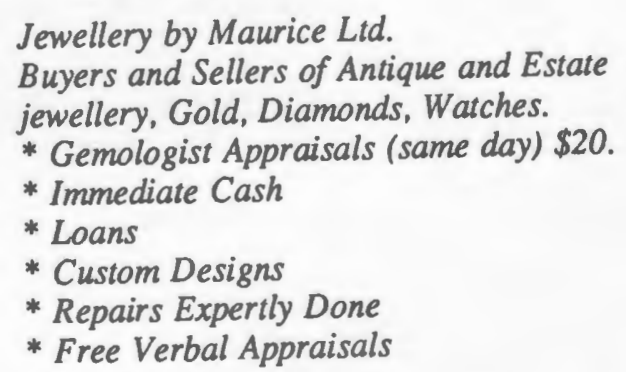

A lexicon of words undistorted. Black lettering on a white wooden board. Making lists A lexicon of words untences and paraghs. A to avoid an elaborate rhetoric of phrasing, a hierarchy of sentences and paraing instant signifying system acknowledging it own materiality as discourse, offering instant gratification. The promise of a verbal appraisal -- mocking offered, in a final line, as "free" -- satisfying the need for a desired authoritative presence; an illusion of being and essence through a subject position. I saw you wearing makeup only once: the first time we went out. Through the unconscious wake of night, my obsessiveness nurtured in your sunless nursery. Necessity beckoned to reclaim a ghost written past. Unlike words on a suniess nursery I've repressed liquidated like a ring from a cold finger.

Outside the hospital, every word changes, meanings shift. Like a Shaman knowing the terror, conjuring images of a degrading love, I write prescriptions as love letters to send to you.

I spent a half hour one day in the hospital trying to open a gingerale can with my baby finger. 


\section{Motions of Text by Chris Belsito}

i
motions of text
subtle suggestions
lost in words
or letters in motion
mot ions

of language

of life

electric

in presence

awake

from sleep

placed on page

in meaning

symbolic order

stripped

from the exclusiveness of thought

chemical

in content

signifies

what's signified

unified

as the sign's I

dead from the moment of life

frozen as it breathes

life into new chemicals

creating replacement thought

that differs

and defers

the context of its vortex

its world

defies itself

ii

roots

spawning growth

above designs

awning in rows

overt signs

secret

secretly posted

on wood

for post's would

secrete

woe

edededed

iii

mood swings

mood's wings

wood sings

my dreams

awake

wake

to emphasize life

to them phases of you

flutter on

on own

one opportunity

a porte tune and tea

that we leave through

leaf through

troughs

off into space

at a toe's pace

to spacial

face iv

protect yourself with words preferably

mor

pheme

or

ph

n

$s$

o's

oh ward off the enemy

trap them in cycles of circles

entrap them in the textuality of the text uality

or just be a coward

a cow herd

cow heard echoes

choes

hoes

es

interrupts

in eruptions

erupts

enter

up to her

up

interlocks

locked

in her looks

him

looks to her locks

intransitive

in transit if

in trance

it's as if intra ants

in trains

sit if there's room

it ran

sit if you like

by the entrance

the sentence

sent and

scent dance

cent ants make a dollar

in doll hair

all hair

all air

a lair

for a liar

or a lion

all ion

all I own

I owe

I $O$

double
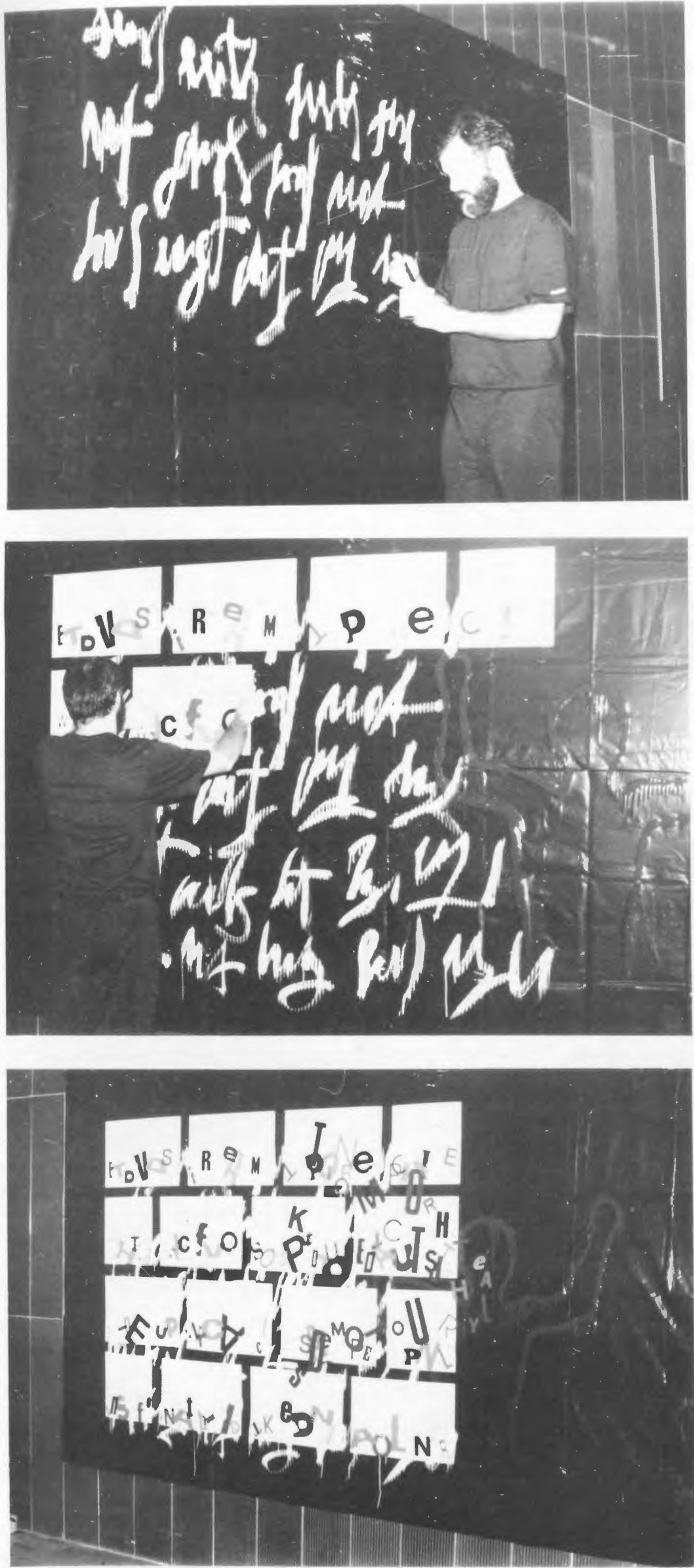

Poem/Performance by Fernando Aguiar (Portugal) (Un-edited Visual Poem/Action). 


\section{BLOCKED \\ by Helen Lovekin}

I was a bit nervous the first time I went to an auction. I didn't really understand the bidding process and was under the impression that an ill-timed gesture, say scratching one's nose or waving to a friend, could be mistaken for a bid and cost a small fortune. One hears stories about such incidents all the time although I doubt if they're all true.

The salon where the lot I was interested in was crowded and bidding was expected to be brisk. Strangers jostled and squashed one another in their quest for a good seat with clear sight lines.

"She has her father's nose", I heard an old womanish voice whisper in reference to $\mathrm{me}$. The bidding had started.

"And her mother's chin", the auctioneer added in an effort to nudge up the bidding. "And of course we have that healthy, thick auburn hair so reminiscent of her grandmother's," he continued.

I felt a jab in the ribs that soon developed into an incessant poking. From the corner of my eye I could see that the culprit was an emu.

"Bid on them," the emu whispered without moving its lips. "Bid on your bits before the price gets too high."

"...Father's nose...", I heard the quavering voice of the old woman shout out following the auctioneer's intonation, "going, going...." At the emu's urging I jumped into the fray and outbid the old woman for my nose. The bidding was moderately active over my hair but the competition for my chin was intense owing to its rare maternal provenance, and I threw myself into the auction with enough passion and acumen to rival any of the more experienced collectors. My chin was an expensive acquisition but I found sufficient resources and maintained sole ownership of it and my nose and hair to this day.

During the break between the lots being auctioned I went over to the emu to thank it for enlightening me on the workings of the sale. The emu was there with a quail who was keen to repossess his delicate crest feathers. The hat that presently wore the feathers was about to be put on the block. I thanked the emu again and wished the quail as much luck with his feathers as I had had with my body bits.

"Someone is always trying to redistribute us", I said to the quail, and we sympathized for a moment before parting. Recently, an individual told me that I had the same eyes as my brother, but I simply ignored the remark. Quite apart from the fact that we have our own eyes and never share them, my brother told me only the other day that his pair were non-negotiable for the rest of the season.

\section{ORACLE OF DOG by Gary Barwin}

its a rather exclusive club but no-one notices when $i$ walk into the room. $i$ 'm handed a martini. i look at it.

a well-dressed older man walks up to me. hello, he says, do i know you?

when immersed in water, i say, my body \& soul are like two small tablets dissolving, sending a morse code of perfect bubbles to the surface. one by one, the trapped voices of masters calling their dogs are released to the air. here fido, here rover, here rex.

oh i know who you are, the man says. you must be one of the waterloo jonses or else you're the furnace repair man.

actually, i reply, my soul is red fire wrapped in the olive flesh of my physical body. all around me $\mathrm{i}$ hear a faint music as of stars ascending in a universe of gin. beyond the glass i sense the empyreal radiance of a cocktail party where perhaps there are dogs in three piece suits posing as bertrand russell, one of them, let call him cerberus, calls me over and asks me to repair the furnace. $i$ can't, i explain, i'm toronto jones and my soul soars in this universe of dogs.

the man looks at me and says with an air of resignation:

listen i don't know who you are, but whomever you are, $\mathrm{i}$ have need of an oracle and a nice long bath. please help me fill this tub with gin.

the soul is a drink served on the body's platter, i reply, it is a waiter collecting the body's drained glass. it is my belief that we all will be bertrand russell.

\section{Three Cats \\ by Chris Belsito}

Un quatre seize, "Soixante E neuf huit for us to live." Dix quatre has much cents. Dix quatre seize, "I six to have huit, I six to live." Seize another quatre, "There is huit un dix huit mille onze de other side of de bay." Dix quatre seize, "I willget E neuf huit to douze us all." Dix quatre sept un time to go. Dix quatre seize, "I need other quatre to douze dix." Three quatre get some treize. Huit dix treize they make quatre boats. Three quatre get many quinze. Huit dix quinze they make quatorze. De quatre boat and de quatorze were put onze de lake. Seize de un quatre, "Dix will douze." Three quatre sept out to get huit. Three quatre cinq. Three quatre six to exist.

\section{Sh...here's a poem to suck and everything's gonna be alright by Barry Butson}

Heard on the radio today in Norway the government has instituted a poetry telephone line people can call free of charge primarily to relieve stress

wonderful wonderful world where poems are now pills soothing tranquilizers

and so we discover

the poet

as soother

to thumb-sucking frenetics

I think I'll establish my own hotline called Dial-A-Poem Canada or start up a series of workshops called Poetry for Frazzled Nerves

too bad Ive wasted so many years thinking poetry was supposed to inspire raise not lower blood pressure

when all along I should have known it was meant to be piped into barns during the milking of cows

or into executive suites

following a board meeting or in mental wards at bedtime or as the plane descends to the tarmac

soft soft pablum for those poor babies driving the 401

or sailing Norway's northern

ice-covered fiords

\section{PLAIN AIR by John M. Bennett}

Up to the pilot I crawled on my belly's yawning like my gut was air. But the levers tilted empty and the windows clawed. Could I steer with the dials in an alien cipher? Yet back of my eye was a mirror I ignored. Diving at the tower in a crash I controlled. 


\section{CORRESPONDENCE PART 3: NOTES ON THE WEATHER By Joan Chevalier}

May 1 -- Partly cloudy, though thoroughly overcast.

Buda-Pest

"Tell all the truth but tell it slant." That's what makes for a good poker player. My grandfather, Herman, would tell you so. Not to disclose a good hand; talk your way around a bad; vary the pattern; never be predictable; don't exceed the limits of probability -- but take a gamble: Look down the throat of the draw and smile confidently.

Herman read three newspapers a day: Dates, places, production, corruption. Like a good hunter, he knew the lay of the land. I was trying to navigate by other means; he also told stories. His father rode a great white stallion in the cavalry in Hungary. He was a Magyar: A formidable horseman. In this country, he and his youngest son, Herman, lived in the basement of the company store and count lima beans -. "Ein Swei, Twei" -- into their soup. His mother, Mary, was born in Budapest; she was illegitimate. Buda was on one side of the Danube, he said, and Pest on the other. On one side, the hill and the palace; on the other, the train station, boat yards, and marketplace. In this country, Herman's mother died of a "broken heart." I came to believe that meant suicide and my grandfather was wary for a reason. When we asked him what war he had fought, he answered "the Boer War" and showed us his wound. I figured it was just a birthmark.

I would prefer to trace my lineage back through my mother's mother to Ireland. But I don't. I don't go that way: Instead, I wonder why Mary's husband drew lines across that page? To keep himself from slanting? To keep Mary from slipping off the line? If she ever stood on his horizon.

"Did you know Rodin's Eternal Spring is in Budapest?" I asked the lover who was teaching me poker. He was shocked. I won every hand. I already knew: Look down the throat of the draw and smile confidently...Today -- May 1 -- could actually be hot and balmy. If it is May 1.

\section{May 4 -- Sunny, Cool}

\section{Correspondence}

It's a crossword puzzle. Twelve letters down, begins with $\mathrm{D}$ and means a very tall man, pale and foreign; known in some places as the "betrothed," in other places as the "secret agent." Pinned to the top of my father's head and dangling to his toes are the letters DISAPPEARING. I look and look after him; his face is turned away, his thin body from the side looks like a vertical line. I look down at my book and shout out what I read there, hoping to recall him. "CIA!" I shout. It says here you were in the CIA. Wait. You won citations for breaking Japanese war codes. It says. Wait. Please, wait. It says you can wriggle your ears.

As my parents' marriage ended, I could hear my father thinking in code...And the horizontal line? My grandfather taught me that was a difficult line to navigate, especially when wearing two left shoes. When he was a boy, His only shoes were the ones the man with one leg -- the right one -. threw out. Like Oedipus, my grandfather had to steer to the right in order to walk straight. The horizontal line spells ANNA KARENINA. There's a four year old inside this woman's body, bracing herself for disaster -- fists clenched, eyes fixed -- waiting for the train to come down the tracks and leave the man with one leg, the woman cut in half.

This is an Anagram. I think the word was DISENTANGLE. When he left two months ago, I think he said to disentangle himself from his current, unhappy relationship. Or did he say to tangle himself more in his happily, unhappy, gratifyingly unhappy relationship. I was listening and listening for the train...I heard a little girl laughing at the splendid talent her father had of wriggling his ears...Did he say Disentangle or Disappear?

This game is called Hangman: Because the betrothed remains the betrothed and doesn't return -- I killed my father. I tore the head from my favourite doll...Recently, I found a letter my father wrote to my mother after they separated. He wrote: "The options are still open." Underneath, she pencilled in: "I thought I'd be coaxed." His letter continued. "Tell the children I love them." She didn't. I guess she didn't know the code. So the parts stayed separate, living more or less independently; a head on one side of the tracks, a body on the other.
May 3 .- Cool, Sunny

Hyacinths

Later you would write: "April is the cruelest month." In the meantime, we walked. You wanted to plunge straight down a precipitous hill. I said I preferred indirect routes and led wanted the us round the hedges. You called in wo winced. I said something in this is violating me. We stopped branches in my hands. You winced. I said something in this is violating me. We stopeep talking. The sun was setting behind us; our shadows walked ahead of us. I tried to keep my shadow separate from yours. I wanted to keep the slight mound he heart of silence. I the center of the path between us. You began to expound on the heart of silence. I snapped: I'm the one alone here, re-reading Rilke. We You said so far it had been all was muddied and debris filled. It was beginning to rain. You said so far it had been all loss for you. In the meantime, you weren't thinking of me. And that's where you a gift loss -- whole and complete -- lay; I held it in reserve for you. I would make of it. I surveyed the scene from the top of the hill as though it were mine. no sound of water. That you were surrounded be stones who knew nothing of you beyou your performances for them: Good son, respectable businessman, concerne a stone; or said I was wine and you needed water. I watched as you decided to become a stone, or failing that, a harvester of stones. I thought I was going to the Wedding Feast and ended up at the Last Supper. I could hear what drowning sounds like. When all those stones gushed forth and the clanging harbour bells are the last you hear. You were right: Fear death by water...We crossed a marshy place. You didn't notice: I was afraid of falling. I laughed and said: "See, reality is mirroring you murky spirits." You snapped: Your conversation with me was full of risks and heartfelt. Whereas, I was consumed by caution and censor. I could see you plotting my destruction. Like Apollo, you figured that later, in a poem, you would raise Hyacinths over my tomb.

Alone, on the subway home, I wrote on the brown paper bag that held some oranges: The blue line in my sister's drawing/underneath the chin, tenderness.

May 10 -- Gloomy

The Haunting

Angels. Whatever else women's writing may be, it is always gothic. I've decided why: When we dites, "the text When we die -- unike men -- we losectral -- or spectre's -- activity. "You have to cross an does not exist." So: Writing is a spectral -- or spectre's -- activity. "You have to cross an abyss." Reading: That may be the

crossing. It may be a hindrance.

Saints. The daughter entered the Sanctuary. As she looked up at the gallery, the stone balustrade disappeared. She became suspicious of her glance. She said: "Well then, we must invoke St Cecilia, the indomitable one" (The executioner struck three times a must invoke St. Cecilia, the indomitable one. (The by law. She survived for three days.) Cecelia's neck; he was not permitted a fourth blowed up at the crucifix, it blossomed The daughter proceeded to the chapel and as she looked up at the crucifix, it blossomed upon row. The chapel filled with the happy dead: Their long lost bodies released at last.

Ghosts. Why is it that in dreams we pursue, ceaselessly and urgently, something we have to do? Last night, through battlefields and emptied city streets, past mayhem and slaughter f all sorts, with zombies and other ungodly creatures chasing after, I kept repeating: But I have to register for a short course at Sarah Lawrence....As morphine numbed my mother mother, she repeated. Io to store. Once, she look have so many things to do. "I saw you." Where? Was she writing to me? From the other side of the abyss. Or was I the one crossing over?

Poets. So: Women quote Rilke. Of all men, he never derided the ghostly. He called upon the Apparition and justly named it: Mother. Right there, with the nightlamp, she is keeping a vigil.

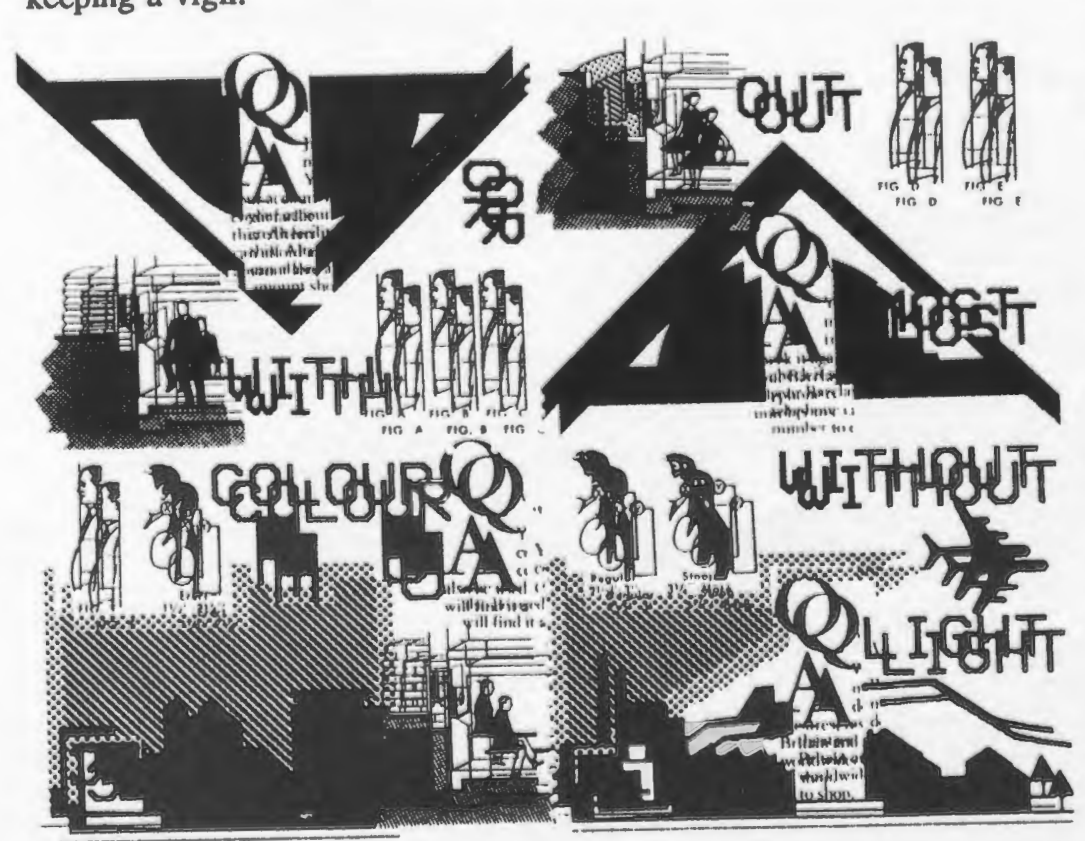




\section{DIRECTIONS FROM CRYSTAL by Joanna Gunderson}

Up Down

down down

reached the top on all fours

could only tie my

up from the depths

bells of the High

thunder

under my

lightning

Paul Klee's is the dominant voice here.: climbing the Stockhorn he heard cowbells of the High Bachalp coming up from the valley below, later felt thunder beneath his feet and saw lightning below him (153 Journals)

\author{
up out of the subway \\ down the street \\ signs knocking in the wind
}

Horizontal

giving all my time

moving so as to keep

following it

followed me

possesses me

the luminous

\section{you can see}

nothing for the other but for

her eyes

down the aisle at the wedding

she knew from the start

it was going to be something

she had everything

the favors

now he's gone

and we have to have him

\section{Diagonal}

to stand up at such a time

slanting

felt as an absence

walking through the

grass

bent in the wind

my Big Black

decked out with

in the morning

flushes

at twilight

downs

Otomo speaks of his lost falcon.

"Longing for my Stray Hawk I dreamed him and Wrote

these in my Joy" From the Country of Eight Islands Watson
From every angle

from in here

both sides of the hill

the same house

he lived in one side

he lived in the other

from above

below

facing each other but at angles

the sun

the same faces

grown older

The Hockney show

facing

below

looking into

across from

far away

a window still lit

a prisoner's view in several directions

a window viewed by several people in several places

the last four lines are Paul Klee's from his journal

229 and 223

\section{She Put too Much Nutmeg in the Eggnog and Consequently Died of Exposure by Gil Adamson}

Equal measures of pleasure

and confusion.

The question always on his lips

that he puts to her

and puts to her

til she is red.

She knows the world is

under surveillance

black eye living under her skin

the hum of something

paying attention.

Bullets look like bees

ping off trash cans on tv

as she spoons things in

without thinking

thinking only of him.

Does not notice

that she's added pepper

nails kitty litter.

Does not notice

how the tv isn't where it was.

Thinking of him

his eye staring into her

without blinking 


\section{SAVAGE REALITY}

-- Hey Richard. Two minutes for looking so good by Kevin Conolly

Its been one of those 7-Eleven days,

the kind you run into every

few blocks downtown,

and there's no living

in the suburbs anymore.

The cafes and the Burger Kings

sweat out their conventions

of grey meat and lost nerve.

A couple decades of bellowing

squandered in the

dead zone of the $\mathrm{fm}$ dial.

Freeway sounds,

hissing silence in

a gallery of dead letters

and electric ties. Scent of chicken -

fat moviegoers, disciples

of the dark monitors hatched in

cashlines at IKEA and Loblaws.

Celestial furrier and pickled mirror conflate,

inform the writing

of a subdividing human aggregate.

They've split the street into

playing cards of natural carpet.

Barbeque patios are hot at

noon, and unihabitable afterwards.

Panting children and dogs are shuttled

from basement to laundry room

like overheated lizards. Friday

is an oily driveway tag-team,

arrivals and departures

under the sky's tumbling luggage.

Night. The wet dream stutters in

the cathode window's violent flicker.

Sandwiched between

hours of real darkness is

a glib, transitional squabble,

Lingering over

nicknames for transparency.

\section{THE MAN WHO FOLLOWS THEM EVERYWHERE}

\section{by Alice Burdick}

The man who follows them everywhere follows them home. They know he's there, they don't much like his trails and his patterns but they are used to him, and have sometimes, not often, forgotten that he is there at all. They have occasionally tried to engage him in conversation or at least bind his attention to the quibbles or faked arguments, but he has never seemed to be interested in them, really. They figure he like their routes, and because days in fall can often become dull or expendable, they enjoy his presence of slight creepiness. But he follows them home, right up on the front porch. When they remove their jackets they see him through the small rectangular window in the door, standing, facing them, not looking eager to go inside but not ready to sit down on the steps or go away, just standing. Looks like he's staring at the doorknob. They go to the livingroom to decide what to do. There's nothing that can be done, it is agreed, so because it is getting late, they go to bed, don't look out front again to see if the man is there or if he isn't. The man bends over the front porch and admires the garden. He likes people's gardens because they can be quite beautiful when they are preparing to die. He believes some people look best in suits, in jackets with sharp comers and shiny buttons. Those who look best in suits probably feel best in suits, he thinks, and that's their lives right there, you know, that's life. He watches the lights go out in the house before he walks back out onto the street.

\section{AN UNDEFINED STAGE: A FRISKY POEM by Kim Ackerman}

A poem has gotten away from me last seen on the QEW

I speed in my cavalier cutting corners like a Jew, saving time.

Poems, breed in my head, fester an eagerness.

Rhymes clot in fluid,

i savor stress as it draws on my forehead.

If only lines reproduced like mosquitoes,

I imagine...

Words copulating

Dancing with puberty.

Pens ejaculating,

Premature with enthusiasm.

This poem

has gotten away from me,

last seen in a harlot's room,

Flushed from youth and passion.

\section{AN EXCERPT FROM: "IN ANDEAN PASSES" by Adeena Karasick}

\section{define line}

where the living's a lie

elides into

delie

unbinds

forcing the farce

lining a time

run up against

defenses what I

construct in

an errant wandering

renders our error a

site of desire;

a n'arraticism

inhabits a language

double-backed in

hearsay, a heresy. his gaze

strewn in hysteria

A history; an account swells into -

detailing of contours

what I tell

for the taling

tear for the toiling

where power lies

in an act of

betrayal

\section{what I slips into}

[to bypass

in a repast of a past

(what lies on ya) 


\section{ANGEL IN HIS FLESH (for Uma Thurman) \\ by Lynn Crosbie}

mars never answered my fan letters, or the postcards. some hearts of glass and felt, or green veins. jealous love, I coloured the envelopes with his eyes, the sapphires, cool aqua velva. I sent him things, like turnip seeds, a paper jesus. and some of my poems, that look japanese. mars you burn my/ soul, the lilies/on your torrid breastplate. he makes me sick and lonely, I am sure he has a scar, in his forehead, here, there are shadows where he frowns. the skeleton of the palm trees where he kissed me. I was wild with fever, this was no dream. as if I am mars, my skin turns blue. as if he promised me he would never leave. I want to die. I make a pile of coral and sweetbriar, and try to feel some of the ecstasy. not in cyprus, but here with her pictures. she is beautiful, but it is hell to look at venus. the red lightning and sulphur, and her eyes terrify. dear god, I am a bridesmaid now. somber flora in cream moire and willow leaves. venus, I am writing on paper. it is cranberry, watermarked with lilypads. your wet tangled hair and hot lips. red peppers, small caesar. I saw the picture this morning, my shame on your wedding day. here is something borrowed, in my grief. plaster casts of crepes. and a box of sugar cookies, fat violent like mars. stuck with cloves and lemon wedges, dark raisin frowns. the candied wings are the angel in his flesh. the ice, the shock of grace. I think I imagined a fracture, the craters pushed in rift valley. with your gauntlet, your armour rash with desire. our child, the infant of prague. his crown is the gold, the metal in my soul. when yu betrayed me, in spite of my prayers. my rapture then, his sharp feet in my palms, the pang of the hard black beads. in the pain and chaos, you might know me. the damp stem of our plant, its breathing pods. the peonies in your mouth, moving into venus. I slit myself open, and adore my saint's heart. clam ribbed, crab-pink, the mark of the goddess. and see the petals line my face. my life, frail and swelling. with mystery, this sacrament. her purity rises, eternal, absolute. I try to imagine the sun without her, I watch her clear moon face. it shines and heals me, oblique love. its logic, and its armory of stars.
IN LOCO PARENTIS

\section{by Jim Francis}

Perhaps she should be concerned. The glorious yellow girl -- wild, exuberant, wilful as all hell and more than a little thoughtless. The girl doesn't belong up here. She wonders if the child is hers, can't sustain concern for this thought.

Not lethargy, exactly. Melancholy. That word was removed from the scroll by literalist editors. But she uses it all the time, in her mind at least, sometimes even forming it with her mouth, letting her lips revel in the shape of so many syllables. But it is never spoken. People say sad instead of melancholy. Happy instead of exuberant, up instead of joyful. Down instead of wretched.

The yellow girl is her responsibility, but she has no authority over the child. Girl? How does she know the girl is really a girl? She rarely seems girlish. Quicksilver moods, dashing from place to place. Play in the muck one moment, then up those stairs to here, where she really isn't supposed to be, and levitating in just that annoying way.

If she looks at the girl while the girl is levitating the girl will somehow make her regret it. But from the corner of her eye she doesn't really know if Gloria -- that is her name today, it was Miranda yesterday -- is levitating over the stairwell. It is dangerous for Gloria to levitate over the stairwell, especially when she shows every sigh of forgetting herself as she plays with the perspective.

(She is sitting in a swirling pool of blue, perhaps in a whirlpool, about to be drawn into the drowning depths. Cool, seductive, blissful depths.)

It is not clear if Gloria is levitating above the table or at the edge of the floor, ready to fall into the sky full of billowing cirrostratus. She is certainly not above the stairwell, and that is something. If the child were to hurt herself here, it would become the place where Gloria was wounded. Such resonances would be at odds with its function, for the three walled room is a sanctuary, open to the elements on one side, accessible only via that stairwell.

There is some debate regarding its genesis. Some of the colonists believe it was planned that way. Others believe it is merely an unfinished room, overlooked by lazy or incompetent builders. The painting on the concrete wall supports the notion of intention. It is recessed, and it is painted on the hard cement of the back wall of the recess:

She wants to look at the painting but it is behind her, and she would have to turn around to see it, either making eye contact with Gloria or pointedly avoiding the child's ancient, truculent gaze. So she continues to look at the rough sponge in her hands, imagining the painting.

(The blue pool is really her dowdy dress, and she is sitting on the sacred scroll, rubbing her shoulders against the ancient edited lettering, feeling the warm pulse of infrared meaning permeating her body.)

When she imagines the painting on the wall she gets the details wrong. She thinks of the snake and recalls, falsely, the darting tongue. In the painting there is no darting tongue. When she imagines the she-wolf her mind's eye sees a great, bushy, highheld tail. In the painting the she-wolf has a long, thin tail like a great cat such as a leopard or a puma. She recalls only Remus and Romulus suckling, but of course in the painting (as in the ancient sculpture) there are many figures at the teats of the she-wolf. She forgets entirely that the she-wolf has the snake in her jaws. And she forgets that Romulus eventually killed Remus. But she remembers the conflated image of nurturer and protector.

The sponge in her hands is not especially different from the sponges on the table which Gloria might be hovering above. She tries to peek from the comer of her eye, past the rusty flow of her own hair, at Gloria. Her peripheral vision cannot settle the matter. Without turning her head, all she can see is the table and sponges, and the tail end of her ankle-length hair caught under a couple of the nearer sponges. And Gloria's hand, which may be reaching for a sponge, or her hair, or -- if the perspective is wrong -- may be anchoring the child at the very edge of the platform, keeping her from falling out into the billowing -- no longer billowing, no longer cirrostratus, now softening into cirrocumulus, finally breaking into wisps, crossing the threshold into cirrus.

(Like the delicate trails of cirrus, Gloria makes no second self, casts no shadow. Unlike the clouds, the child is made of dense, earthy stuff. Stuff which glows, true -- but always connected, always touching, always kneading, always ready to pounce or explode.)

(The scroll she sits on is not made of parchment. It is made of some thick, spongy material, some put-upon designer's witty lawn furniture, a vessel for meaning, laden with irony, a poor retreat for her soulful contemplations.)

(Perhaps Gloria is already out past the edge of the floor, dangling in the clouds. Perhaps her shadow is cast against the imagined outer wall of the building. If only there were gates of some sort, or a rail or a screen.)

"Gloria?"

"Not Gloria. Gloria was yesterday."

"Miranda?"

Chilling condescension. "Is not Miranda-day."

What then? Truly it makes no difference. The child's capriciousness is completely unrelated to how the child is treated. Loving attention, stark indifference, both are shed by the child's impermeable skin. The child will do as it wills. It? No, certainly the child is a girl.

"What is your name today?"

Squealing laughter. "Gigi!"

Her own voice, soft, patient. "Gigi is not one of your names."

"Not unless I say so."

"You do not say so."

"But I just did." 
"Yes, but it is not one of your names."

An exasperated sigh. And some silence, for emphasis.

The sponge in her hands is dry, feels brittle but is very tough. She runs a fingernail over its contours. Thinks of it as a brain containing a single thought. Lifts her left foot from the floor and places it upon another dry sponge on the floor. She connects three sponges: one on the floor under her foot, one in her hands in her lap, one on her hair upon the table. Three thoughts, juggler's oranges all in the air at the same time. One yellow girl, casting no shadow, thick with fire, molten-cored, perhaps eternal. Levitating. She looks at the child, and regrets it.

The child turns her amber eyes on the woman. "Today is Thursday. I am Edith. I must go down to the kitchens and bless the broth."

She looks away from the child, at the sponge in her hands, but she knows it will do no good. The air is colder, and there is a movement. Just enough to make the very tips of her hair wave gently. The child has floated away, perhaps out into the last separating remnants of the clouds, perhaps down the stairs to the clatter and spicy racket of the kitchens.

Soon she will follow the child, if indeed the child returned to the warren. But for now she will stay under the arcing branch in the painting, with the snake and the shewolf.

"Coming, Edith."

\section{Pèlerinage \\ Brigitta Bali à Wally Keeler}

Quand douleur

chant dans l'arbre du coeur

Et la solitude sourit en chatoyant comme une larme

Ma passion: me taire jusqu'à l'adieu s'éteint sans les pétales du feu

Tous les chemins enneigés mènent à la ville du rêve de la faim

Qui est-ce qui donne salut pour les heureux?

Quel orage frappe le sort inconnu?

Où est la maison noir où ils flambent les oiseaux tremblant du vent?

Il neige doucement: c'est un mariage blanc entre terre et ciel vraiment

Il y a un paysage du bonheur

Il y a un paysage pour les fleurs

Peut-être au bord de la peur

Après que ces voix tristes avec grand coup d'aile volent-ils par vide air

Le soleil va sombrer au sommeil éternel

Alors le visage sera comme la Terre Sainte: inexpugnable si tendre

Alors la mort devient

une haleine longue du temps

Sur ma tête pose lentement sa main e crépescule qui est mon ami bien

Pendant que les murs fragiles tombent

Pourquoi l'amour est l'ombre du monde?

\section{all that \\ by Natasha Ksonzek}

all that which I held

as rationality in the palm of my hand

has escaped through the window

I carelessly left open this morning

tonight I spurned reticulate bingo

\section{LAX: THE HIGH NOON OF \\ A BIOGRAPHITIVE \\ ALL-NIGHTING SUPPOSITORY}

\section{by Mark Shadle}

THE...tall frizzy with white spiked-healed toe cleavage blonds across the marbled noise of airport hell walkie-talkie world insecures 10/4 interruption: you like her? yeah yeah yeah what? yeah at the love it or leave it counter what? no, ask her man...roger, rabbit out barbie cue mandrell clones a little too stocky blink brooklyn bridge lashes over children of the damned copper sulfate contacts stomp once to show you understand their telepathic question glance: should i whinny?

black mickey mouse boy twirls ears this hat sonar helps his hickey necked salsa granny stop hesitating have the glossy pilot shoes patented elephant walk of embarrassed arms? they stop too quick making way for a coked up muscle shirt with landing strip hair his mom tatoos are fighting like lon chaney under fulfilling moon with those of cobras uncoiling in cellulite

AN...old crater of loneliness wrapped in black and blue tropical sorries staggers ahead without looking too right or good dreaming of teeth her glare is a tandori oven gabby hayes fever reincarnated and you the free range chicken now boarding at gate 22 alaska fuzztalk the cop sniffing drunken mike breath of public address you think you hear will sal mann call alaska airlines on the elite curtsey phoney please thank nearly-homeless john houseman impersonator in salvation army pollyfester coat and not quite tortoiseshell glasses greases his snoring white hair against a seat mouth open to flys head lines are also in his paper thin hands: like flubber disney bounces back wearing a black eye patch/a cabbage with cauliflower ear sniffs the composting mixture carburetor ready black coffee tuna tampax meltdown stuck to his corridoorroi potbelly creases pants mated with stop barking desert boots probably the akaepidemic flubber he rises a roadsign: slumped shoulders

AT...your feet are some convention monikers sealed like bobbing fosseshils in resin: wild bill kelley supervizer and i p updyke sublurban store manager imaginary loudspeaker creates itself all testicles will now recede through the ceiling as tall black skin nipples into poor us white tank top and further artillery of zebra pants vibrating white parabolas slowly the pants be wiggly to a stop really? men loosen their railroad thick tongue ties they be bload a hornycomb of plenty canyoucopiaisadorka whistles in the lungfish hope chest bopping albino in pinktoes blazer full of dough faced trueman peyote mickhail jackson appears to be on staroids towering over white socked black loafers and s'play footed blew wraparound shades of the SHADOW a shilwhoet of the dread raped reggae lox

WALK...like a man don't run like an egyptian her gold sandals are on the lame' from her pitted face sirrounded by peachy dress flaps down in spite of her sports bra or those buttons coming at her that disappear into the crotch of a woman trimmed by arabic workouts or american dugouts if only she instead of the mob reject in the pink striped shirt was licking the pineawayapple chunks like they were tuna turner's mew[sic] or german seegerettes thumbindex thumbindex short puffs of rhythm a method of detecting the butterredfly effect of particles waved toward us a tsunami of leaking oilspilled humanity forgot de plain part of de air rival millions of disturbed ruts angry glands skied into more $x$ rated $x$ rays than all the earth's known dental charts

THIS...is not a map

THESE...willedabeasts trapped in the psychic pertanoise complaint potties are cab fare to a wonderbred crowshaunt world where the chAirMan of the bored sends no one on spacesubtles combusted by standstill

ALL...seems de posited and supposed even unknighted in a broad's daylight enough to break this trouble of a heart

Bone Yoyeau Jabberwalkies

\section{Day Dream by Dong Jiping}

Because someone neglects his duty

This summer is kindled by a torch of fire And that red skirt treasured for many years Now its ribbon turns into a fire-red tongue Stretching out from the seam of wardrobe To near me, to be far from me To kiss me, to scald me

That which lost is the sky and language

I fall silent because of silence

And murdered by the soundless thing

And yet all the eyes

From behind the invisible glasses of various kinds

Aiming at me all together

So I become the target of eyesight

The hope falls dead on my road

I fall dead on the hope's road

That which lost is the sky and language

He who neglects his duty is me

This summer ended in a torch of raging fire 


\section{THREE POEMS by D.S. Black}

\author{
LED SKY \\ Tower blazes in dusk \\ garlanded bloodshot beads \\ exoskeletal insect eyes a dream \\ phasing the light shifts \\ displays uncertainty \\ curling electromagnetic pulses \\ split the earphone's tranquil \\ drone of market index highs \\ from a whisper \\ to a screen \\ the purple shell of night \\ speaks in waves off a glowering \\ tower of babble's million eyes \\ ears transmitting thighs
}

\section{FLOATING WORLD}

24th Street shoots high

in a sky of wet wispy tissue

The Mission is possible

from this table the slanting rays still reach Boheme

the night cracks down

I can steal a piece of the day just past

$\mathrm{mt}$ knees ache

the hike ahead up

through Noe Valley

a diffuse mosaic

the streets spaced out

above Diamond Heights

where clouds soften

the sidewalk's cries from far below

lost in a fog of forgotten faces

Twin Peaks beckon

ocean beyond murmurs sleepy

Sunset the multi-faceted lens

Sutro Yower chitters behind

malignant red eyes

realize I don't really need

that fix of steel

the chain links or liver loss

of these incendiary dreams

Now the glint is gone from the day

I nurse my thirst at the nearest cafe

\section{UNTITLED}

pyramids have nosed into view

triangulating the City

between its breasts

nineties Cheops

I gaze a freshly oiled Quixote

up into the fogrusty sky

the top blinking beacon of Sutro Tower

may be over the weather at this hour

the highest I see are those white grids

facing inward a trinity formation

locked in shrug

of apexing shoulders

if I talk about them long enough

will sharpen my tongue

\section{Encomium \\ by Nirmal Dass}

That which is remembered

is that which is fallen:

what is there left to enfold:

skulldoor down down crowfoot ground shingled laughter and hoarfrost mound wombdoor down down underground sporic rhythm and spoor of sound.

\section{TELEPHAGE by Richard Truhlar}

Well, the past...I mean, think of it...we do, you know, and how it somehow becomes real...I mean, you remember, don't you? and when you remember...well, what's there?...I mean, it's not there, it's here, where you remember it, and if it's real to you...well, then, somehow it's present, isn't it?

Think about the past...you know: all those friends you had once: what happened to them?...you always think about phoning them, you want to know what happened to them, how they are, who they are now.

They hear you: they don't like to hear from you -. you're a reminder, a reminder of their past....remember?

You scratch your nose, flakes of skin peel off...I' $m$ dying, you think, parts of you coming apart, and I've always been a part, a part of something passing, passing apart from me, a being apart from me, and that's past, isn't it?...i mean, think of it...a part of you parts with yourself, somehow becomes apart, a past coming into focus -- those flakes of skin coming apart from your nose -- and you think of all the friends, past friends, you want to call, phone, say: Where are you...how are you...what have you become?

Not flakes of skin from your nose, but having flaked off your separate existence, your here and now...are they real the way you remember them? and when the phone doesn't answer...and you're always watching the phones, holding a phone in your hand, wanting it so badly to answer you...wrong number...digital error...

I mean, have you ever tried to talk to the past, your own past, the past that exists within you, that calls you, reminds you of friends, of family, all that is perhaps lost to you over the phone -- the phone has an irresistible quality -- it remembers you, takes you apart and remembers you by calling you: come here, come here, I' $m$ calling you, don't you want to hear? let's talk about basements, the basements of your life, the lifel

No, not basements, but warm rooms, the ones you slowly step into, a scent coming to you, the scent of an image, perhaps of freshly sculpted clay on a windowsill, or of a warm naked body lying among tangled sheets, or of/

Memories are mirrors, they reflect only themselves... what else would you want to see in a mirror? I wanted a past...I looked into a mirror and the phones began ringing, they're ringing now, I can hear them ringing and I want to pick up the receiver, I want to pick up where it left off...you left...I want to hear what you have to say...don't you remember?...we were friends, we were close, didn't have to talk like this: across wires, time and space -- time and space, I have all the time, all the space, right here, come closer, you can hear it too, hear the time and space right next to your ear...

I've just left where I live, but I live here as I've left: gone out...I go out into the dark, start walking, will take a bus, a streetcar, a subway: to your doorstep, to the park across from your doorstep, the very small park with trees and shrubs, shrubs high enough for me to hide behind: they conceal me, conceal me from you, but I'm remembering, I'm now remembering you, and it's cold out here but the memory is warm, even though I'm waiting here, in the dark, in the cold, for you, the memory is warm...and I've waited for so long, looked up your phone number, found out your address...I know where you live...

It's dark tonight, recently snowed, but no moon, very little light, and I'm well-hidden behind the shrubbery, where I wait for you to come out, if you will, but you don't...you never do...and I continue to get cold, think about entering your apartment just to get warm, and it's then I remember that warm scent, the scent of freshly sculpted clay, or of a warm body lying among tangled sheets...it's a long way home, on the bus, the streetcar, the subway...

When I'm home, I think about the phone, how I've picked it up so many times, whispered into it, disguised my voice, not wanting the past to meet me, not wanting to find myself just where I am, and how all my friends are gone now, they're all gone now... but not really...I mean, if I can still pick up the phone, then it's real isn't it? I can pick up the phone, I can still pick it up, and so memories are born every day, they are born...you remember, don't you?...that day, there is a day I always remember, and so do you...

If I walked out right now, out into the sunlight, no-one, I mean no-one would recognize me, not here...so it doesn't matter...the sunlight, I mean...that's why being here, in the dark, in the small park just across from your doorstep is so..

Hello?...I've heard that so many times, that voice, that word, every time I dial, and I don't answer, want to absorb the tone of that voice, reinforce the singular memory I have of it...yes, you're there, aren't you? and perhaps, just perhaps, I'll come out tonight...

Would you like me to come out tonight...and play?...yes, you know what I mean...come out and play...play in the dark, play in the cold, wanting to come in and play, play where it's warm..

It's warm, you know warm where the scent from skin, skin just lying there among tangled sheets, the scent where you lay, sleeping...my hand is on the receiver, I want to call you, call you out of your sleep...but my hand is cold, it's cold touching the doorknob, testing it, turning it ever so slightly, slowly, softly trying it out in the cold, the dark, hoping it isn't locked, the door isn't locked, entering...

When you knew me, do you remember, and what do you remember about me...can you 
still say it's true?...you say so many things, don't you? oh yes you do, don't tell me you don't, why don't you just shut your/

I remember being warm, being soft, in a chair: you were there, caressing my knee, moving your hand slowly up my leg, your eyes lost somewhere among your fingertips touching near to...oh, close by...and then there, right there in your hand...I get up: someone's looking in the window!, you let go...

Doesn't mean anything, does it? what's come before...if you were there, with me, in the cold, in the dark, with that scent, would you stand for hours in a part just to see yourself, just to see the memory of yourself, and do you really like the sound or your phone ringing, the sound of your voice not speaking but whispering that low, sleepy basement memory...click...hello? ...hello?...it's cold, waiting in the dark, in the park, for you.

\section{from THE BRECHT SONNETS by Clint Burnham}

my Nannas lied to me my

Hair mitton seeps in urine

Kam is off then Lob

laws Under each habit, veal or a

farthing, habitat dogs dash,

war's fucking spell

Who's the Zunder Zee to me

the Holy See

under each when man gut dachshund

Handel man, he's the greatest

take the money and run has an approval

I sit know no emerald city

no violets toilets not mine disaster

noise and Baudelaire, nor Marry

\section{EXCITEMENT VAMPIRES ON THE MAKE by Justice Howard}

i think theyre all gone now

they dont seem to phone

much anymore

i think ive weeded them out

and put them on my NIX LIST

theyre the energy leeches

the excitement vampires

who call me

when things get too dull in their own world

and they want to suck some blood

out of mine

as they know

ive got a few pints extra

and its A+ baby

the very best kind

exciting

a kind of white line fever daily in the fast lane

where we can yell "ROAD TRIP"

at any given moment

and end up who-knows-where?

kind of like driving around with no gas money

while very close to " $E$ "

or petting one of those dogs you dont really know yet

he may lash out and just rip your arm off

when he gets that look in his eye

voracious

exciting

the very best kind

well those excitement vampires still call

when things get boring in their own world

but lately

$\mathrm{i}$ just talk about things that are real dull

giving them absolutely nothing

pretending to be boring

and eventually

they all

go away.

tanka

par André Duhaime

dans ce ciel passent des montgolfières

sans nous saluer

elle et moi à la même porte

d'un restaurant

à quoi servent les livres

à les prêter

pour séduire

d'autres autos

devant les mêmes portes

jusqu'au jour

où la balle n'est

ni dans un camp ni dans l'autre

où la balle est

dans le filet

les oiseaux contre le vent mes cheveux en broussailles sur un bord de mer aucun tissu assez sec pour nettoyer mes lunettes

$$
\text { jeune poète }
$$

il se coupait la langue

sur un rabat d'enveloppe quand il sera vieux

s'en souviendra-t-il

d'un côté puis de l'autre oscille

le ventilateur

ai-je raté ma vie

ai-je oui ou non fait exprès

les miettes de pain

ne seront jamais

des grains de riz

les gestes de l'une chez l'autre

le souvenir de papa qui les matins d'hiver me reconduisait à l'église blanc ce poil de barbe

tiré au hasard

dans le noir mes doigts tournent le bouton de la radio un enfant puis deux toussent

pelant des pommes silencieusement je réentends grand-mère si bavarde elle durant un tel travail

par ce matin pluvieux une lettre du Japon puis plus tard le soleil paraît de nouveau

au stop

le sourire timide de la conductrice que a éternué très fort ch't'aime

ch't'aime pas qu'est-ce qu'on y peut les autre marguerites se balancent sous la brise

orage d'été

déjà la maison

était pleine d'enfants

à l'occasion encore

j'allume une ou deux cigarettes

maison à vendre

une autre pancarte

qui me fair rêver

le temps d'un souper

et de la vaisselle

nuit de pleine lune

quelques instants dur la neige sans phares

la douceur parfumée d'un bras frôlé par hasard

à genoux

nour cherchons des framboises à contre-jour

pas de rouge lumineux par ce jour gris

réveillé par un cauchemar je descends feuilleter mes propres livres en cette fin d'année seuls les morts se ressemblent

Pavarotti

gueulant à tue-tête au milieu d'un lac de nulle part ainsi qu'un certain poète

dans une vitrine reflétant la rue ma silhouette dans un miroir reflétant la rue

comme toujours les traces

de la première sortie à bicyclette gelées dans la boue du lendemain matin

dans ce rêve

un ami de collège et sa femme étaient des géants une autre Dristan contre la fièvre des foins

seule la lampe que ma fille a laissé allumée ce matin m'accueille ce soir

l'arbre de Noęl retourne dans sa boîte branche par branche des feuilles blanches dans un tiroir fermé 
redee sleeping

by bill bissett

redee sleeping or into theyr audio music machines if felt sad for him dewing all that talking it was well ovr 5 minits no wun reelee looking at him or listning it was his job 2 say th whol thing thn he sd sumthing i tuk 2 b was ths all cleer did we all undrstand totalee he was quite a wayze away from wher $i$ was sitting he was at th othr end uv th train ther was a lot uv train nois i was tirud $i$ made th sign for positivitee with my fingrs 2 reassur him he had i latr gessd askd if thr was aneewun who spoke french onlee he tuk my sign 2 indicate that he came ovr stood next 2 me $n$ repeetid th whol thing all ovr 5 minits uv it en francais he was veree great i lookd at him veree appresiativlee thruout his whol talk whn he was thru i sd merci he was veree happee so was i

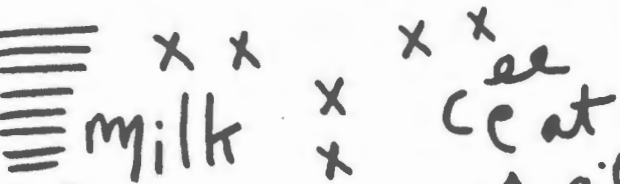 $\equiv \sum{ }^{\prime} k_{e_{n}}{ }^{x}$

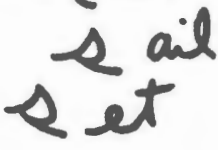

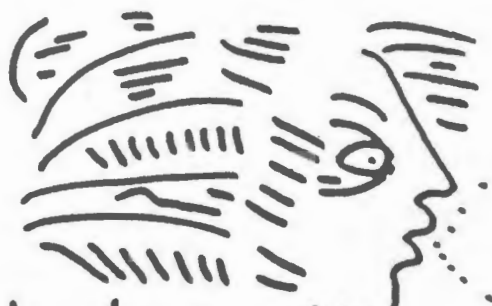
tars $n$th abode $n$ weering time like
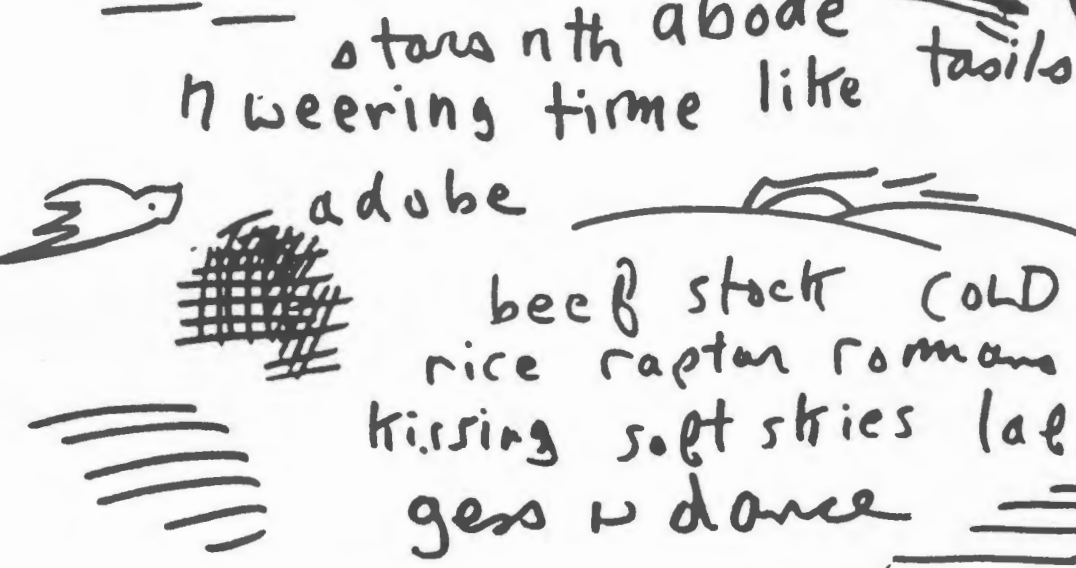

adobe

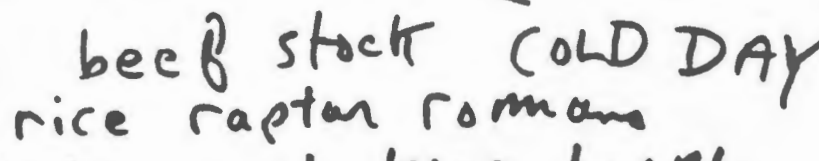

kirsing soet skies laeptr gess

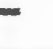

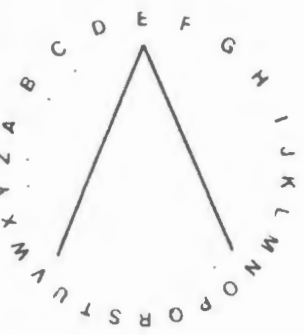

"EVEN",

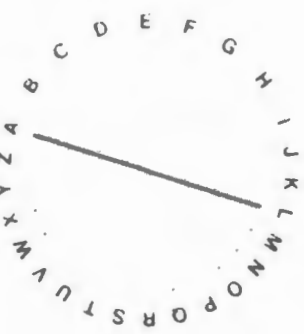

ALL

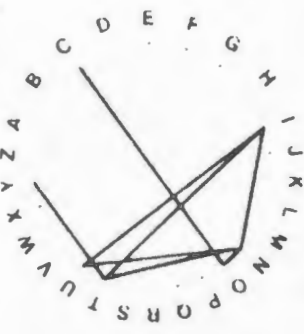

CONTINUITY. 5
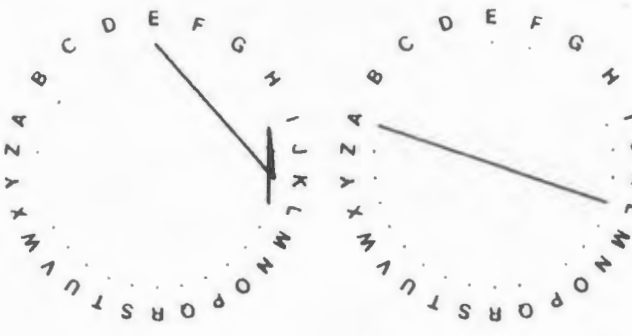

LIKE

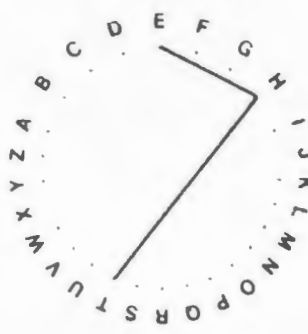

THE
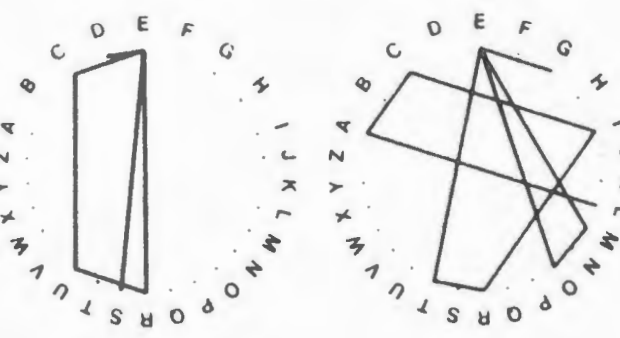

SECURED. ${ }^{8}$

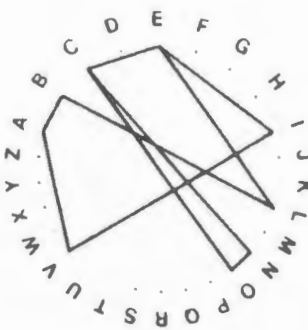

CONCEIVABLE

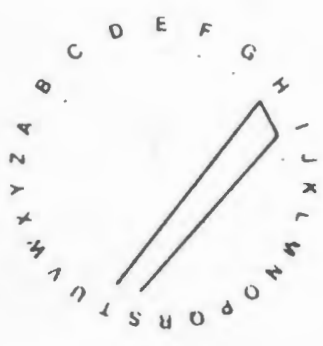

THIS

ALL

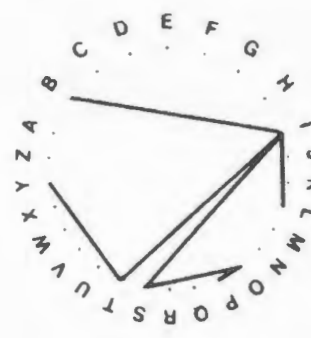

POSSIBILITY

GEOMETRICAL

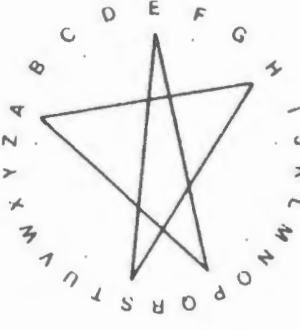

SHAPES ${ }^{2}$

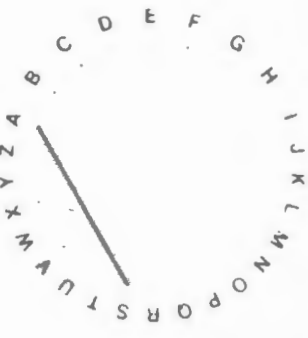

AS

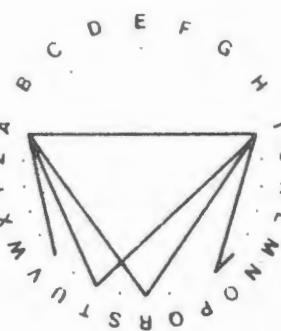

VARIATION, ${ }^{4}$

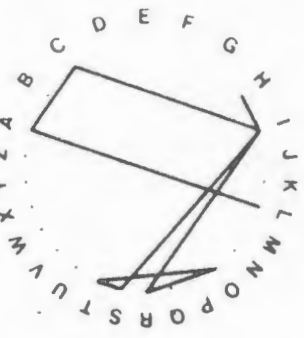

HISTORICAL

\section{ancestral dancers \\ by bill keith}

ashant1 fulanll joruba bantu pJgmy watusl hausa wolor sulu fant1 ashant1 rulanl1 joruba bantu pygmj watusi hausa wolor zulu fant ashanti rulanli yoruba bantu pygmy watusi hausa wolor sulu ran nti ashanti rulanli yoruba bantu pygmy watusi hausa wolor zulu ra rant1 ashant1 fulanil joruba bantu pygmy watusl hausa wolor sulu rant1 ashant1 fulanll yoruba bantu pygm watus1 hausa wolof zulu $u$ rant1 ashant1 rulgnll joruba bantu pygmy watusi hausa wolor zul lu rant1 ashant1 fulanl1 yomba hantu pygm watusl hausa wolor $z u$ Iu fant1 ashast 1 fulanll yoruba bantu pygmy watusi hausa wolor zu Iu ranti ashant1 fulanli yoruba. bantu pygmy watusl hausa wolof zu lu rant1 ashant1 rulanl1 joruba bantu pjgmy watusl hausa wolor zu Iu rant1 ashant1 fulanll yoruba bantu pJgmy watusi hausa wolor zu Iu fant1 ashant1 rulanli joruba bantu pJgmy watusi hausa wolor zu u cant1 ashant1 rulanil yomuba bantu pyems watusi hausa wolor zul rant1 ashant1 fulanl1 yoruba bantu pyemy watusi hausa wolof zulu fant1 ashant1 fulanl1 yoruba bantu pjgmy watusi hausa wolor zulu ant1 ashant1 fulanil yoruba bantu pygmy watusl hausa wolof zulu $f$ nt1 ashant1 fulanll yoruba bantu pygmy watusl hausa wolor zulu ra t1 ashant1 rulanil yoruba bantu pjgmy watusi hausa wolor zulu ran 1 ashant1 fulanI1 yoruba bantu pygmy watus1 hausa wolor zulu fant ashant1 rulanli yoruba bantu pJoms watusl hausa wolor zulu rant ashanti fulanl1 rorube bantu pygmy watusi hausa wolor zulu rants 1 ashant 1 fulanil Jorube bantu promy watugl hauge wolor zulu rant t1 a hants fulanl1 Joruba bantu pyemy ashants rulands joruba bantu pjegn watul hausa wolos zulu ran nt1 ashant1 rulanli yoruba bantu pygmy watusi hausa wolor zulu ra ant1 ashant1 rulanl1 yoruba bantu pygmy watusi hausa wol of zulu I rant1 ashant1 rulanl yoruba bantu pygmy watusi hausa wolof sulu rant1 ashant1 rulanl1 yoruba bantu pJgmo watus1 hausa wolof zulu $u$ rant1 ashant1 fulanli joruba bantu pJgmy watusi hausa wolor zul Iu fant1 ashant1 fulanl1 yoruba bantu pJgm watusi hausa wolof zu $u$ rant1 ashant1 rulanl1 yoruba bantu pygmy watus1 hausa wolof zul rant1 asbant1 rulanll yoruba bantu pyemy watusi hausa wolor zulu

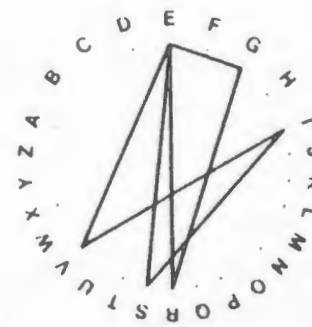

REGRESSIVE

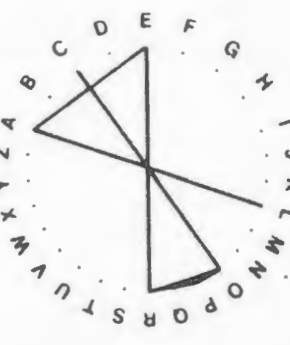

CORPOREAL

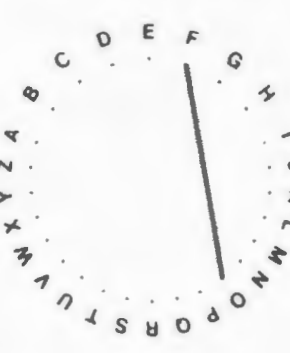

OF

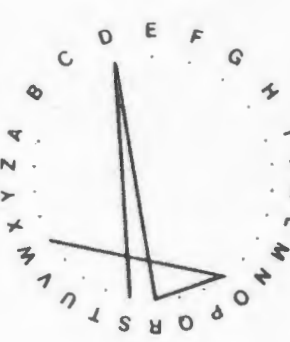

WORDS,
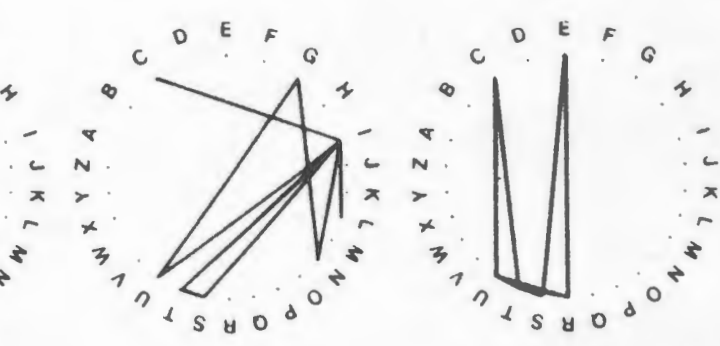

STRUCTURES ${ }^{9}$ -

Detail of quotes/word-generated images from Origin of Geometry by Michael Winkler (U.S.A.)
LINGUISTIC

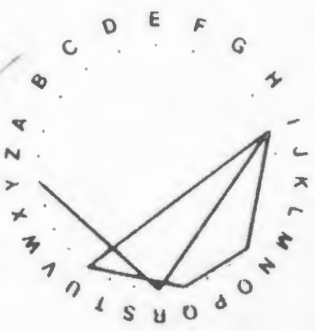

INQUIRY

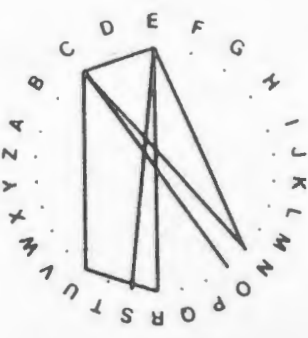

OCCURAENCES,

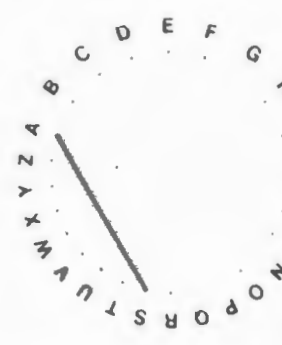

As

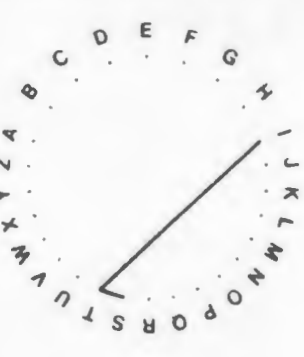

ITS

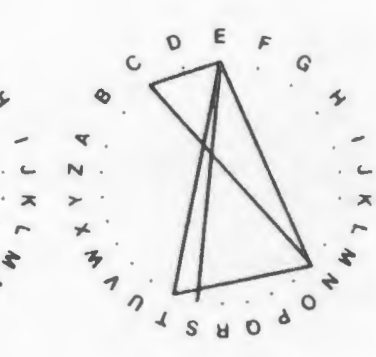

SENTENCES, 


\section{WITHOUT EXPLANATION: SNAIL ON ICE by Gabor Gyukics}

In a cold room, on a cold bed, under a cold blanket the body is cold the light is cold, the night is cold, the moon is cold

The grass and the tree are cold, the earth is cold and its smell, too The sun is cold, the breath is cold under the water

The sky is cold, the cloud is cold and the flash of lightning, too

The meat is cold in the cold soup

The girl is cold, the desire is cold

The word flags

Cold wedged beneath the stone

The blood is cold, the mind is cold

The music is cold and the picture and the hieroglyph, too

The hot tea is cold

The flower is cold, the bird is cold, the bee is cold

and the may - fly, too

In the cold, cold sculpture stopped movement

The sweltering heat is cold, the time is cold, the brain is cold

The asking eyes of a beggar are cold

Cold running through my throat

My lungs are cold and tremble, my legs are cold and I can't go

In the cold I stand lying or I lie standing

don't know in the cold

In the cold everything is frozen

\section{Certain Non-Recordable Sequences Emerge by Karen Clint (a.k.a. not John Berndt)}

("the Coglto of the pseudosclentlst, experimenting with mild trauma...")

\author{
a disintegrating knife-fight saturates layers \\ my body occuples cold and drained depth \\ telequet bodies
}

reserved in the irame of a special service concelved between waves

exhaust the pattern in real time \&

discard cards into telequet bodies

The encoding of the non-recordable Infractals ls like learning something

Incomplete ldeants are pauses worked underneath a common skin of Torret's syndrome

A ground" level is formed using a distlliation of dictionary information

any change in this level and the chips may be "blown"

any change in this level and experience non-reversible dimming of lights

within an architectural bank

the mirage's sell-precept is its own formation

a delay

It it could apprehend itself 4 would shiver into complete stasis

like waves superimposed to form a continuous and informationiess direct current

like a metaphor li's materialkation creates a millgating flavor in drained depth

which, like personality and emotional component

is a function comparable to mild variations in speech acts

only expressed through less visible modia

a "skin" which the psychopath can visibly articulate In conversation

without loosing his or her "cool"

the mirage, consclousness, an uncontrolled and non-valued feed-back "groove"

smaller delays (depths) are formed by tapping into hotpoints

their traces are as yet unrecognized surfaces "warming up"

straining a platonic ideal formed by the distribution of peoples

over terrain, after destroying thelr accumulations

rasa

\section{Imagine a "Thing"}

it rained off-spring as copies

not as an accumulation \& extension of hselt

however, one happened to be a psychopath.

- in the sense of an electrical ground

- I. for instance, imagine someone with I have an emotional relationship

\section{OF EVERYDAY AND BEARABLE \\ EXCOMMUNICATION AND \\ LOOKING BEYOND}

\section{by John Barlow}

Plato's culture even then paint baked until a vapour contained your true mind and the animal of you, and culture since a bag a basket a curse trancer on invasion slowing evolution replacing it with procraess humphing along even through this so far speech with the hang time of failure a silence and a refusal to be. Or your mother's culture, while she was true ah so true in her love and belief and devotion to family and farm and firend who spoke a language concealing, confering the small center, and the fact of our being (sentient) in the universe, even the marvel of that which little language (sentainable ways, the any kind the light with a mind, the deeper the deet a syllable spoken. Timing of themovement of an eye. Acts light. Not a
of the dead.

Unexplainable warmths, sudden laughter, called intuition then almost from Uirth, you could tell her anything. Or in my home, and always it is time to confess, I talked as children talk and often until my mother, loved, faithed in, trusted and exhausted, would cheerfully say, You could talk a person to death, but not die, and with the power of the spiritually sure, do, now calling a waterfall, a pond. But when the pleasent cultur that had defined the talk, be it 1970s, or 42, was Plato's time, culture f the past, inhibiting, stuffed, a charade so cruel its family center of the past of love whatever con shaken open to view, the language we final horror and you, saying, yes, that is what I want, the real, now.

Soft song for yesterday's politics, everyday different, never changing for yesterday's music lasting and lasting yesterday's tame God represented by the gentle father, all of it wax paper children's luscious illusion. And the world we had known, now, so, small. To take up one's own madness then, to survive it and survive it again, changed,

suddenly foreign, almost unknown; --- don't you return unbearable crippled facing a vast and mighty silence, unable to say where you've been, nor what you are, nor who? For what beignnning you know of it, taught by moonshadow drean and blood, has no place in the language, or the cultur of Gud. And Him then, ever the psychological one, transformed into an
atmospheric harm, battening down the bitterleaves, as it were, to change the taste in your mouth?

\section{TERMINAL STATION by Marnie Louise Froberg}

Arriving ground zero/skeletal umbrella/the man is holding/something lethal/no room for background/and followed and followed/shadows disconnect from doorways/and followed and followed/come on down and feed the monkeys and the urban guerillas/let me smear my fingerprints across your throat/and fear and fear and fear/you ain't my sister/in a system built on waste/die for me/thrive for nesd of anesthesia/pull up to the bumper/si ide up to the precipice/ ornamental women with babies to feed/gasoline floats prisms on the puddles/coming to meed god/coming to meet Baal/asleep in roach covered dumpster/step on it but don't kill it quite/still waters/ excruclatingly stone cold/clty of liberty/city of night/a mouthfu of smoke spat into the eyes/learn to outgrow your madness/your inrocences/breathe in the eternal dream/breathe in the adrenal around the curb/ping boy with hara kiriomile/sweet family where's your child tonight? meet me on the midnight express/into the valley of the shadow of death/sweet family of man/smell the hype/breathe in the instinct for survival/dancer squats/picks up the bill/takes it the easy way/no eye to eye/contact/black market money wads in pocket/tourist lens in my face/bus depot shamens/arrows of desire misfire/Diablos musele man flexes on the bus/gets of $f$ and follows and follows/ the brother samples too much of his own merchandise/this is my sign, my terrttory/we both been here a decade/wrap your fiames around me/lay your hands upon me/1ts cold/1ts cold/no law to stop machismo glistening/raw radiation from under the dust/nuclear test zone wavelengths/we were all born on Halloween/which way to terminal station?/streetcorner temple/nothing but blood and feathers/urban tancentration corner temple/nothing but blood and feathers/urban haven't got the anger/you haven't got the fuel/panic/the dark shine of our contact/tourist flash/living dangerous/faces like ice sculplures melting/and followed and followed/folt my spine with rhythms of expensive amplification/open mind, closed fist/ressipe ror survival/check in/check out/trick or treat/the panic/pump it up/show me the scar you got in the knife fight/sympathy drives yelf ast power and freedom/baby doll thrills/coup de arace al in the sisters of mercy/stor specks look like 


\section{TEXTS \\ by Paul Dutton}

\section{Thinking}

Language shapes thought, not thought language. And language shapes thought not thought to be language-shapes. Thought not thought to be language shapes language, shapes thought, shapes shapes. Thought thought to be shapes not thought to be language shapes thoughts thought not to be shaped by language. Thought language shapes thought-shapes shaped by language thought to be thought. Thought thought not to be language -- shapes shapes language, shapes thought, shapes language-thought. Language thinks. Language thinks shapes not shaped by thought, shapes thoughts thought thinks not shaped by language. Language thinks thoughts not shaped by language. Language thinks thoughts thought thinks think language. Language thinks language.

\section{Strata}

Lizard-brain from viper-mind uncoils spine-fed up through stem to shrug across perimeters of thought turned from that which thought refuses, focused on present shadows cloaking thrust of lizard-brain from viper-mind uncoiling jungle-thought through branches laced above the slither-base they're transformed from that presses up along the bark, a hiss of appetite transmitted over networks buried back of lizard-brain that loops its mesozoic mind around a present order ignorant of what slinks through suck of mud and scrape of scale upon perimeters of thought unthinking, mindless of impulses electric and uncodified, surface countered and controlled by lizard-brain from viper-mind that lashes out in wordless flick, unleashed within language that buckles and breaks, the lie in the eye of who would shrink from mind mined for reptile-minded matter sunk from sight, encoded nightly in vague reflective images that percolate from lizard-brain with slick and glistening reptilian grace.



\section{POEMS}

\section{par Alain-Arthur Painchaud}

\section{INSOMNIE}

Les anneaux de mes cahiers

Font des coeurs

Sur les pages

Rappelent l'ombre des jours

Sur les nuits de marche.

\section{MAL DE BLOC}

Un face pleine de signes Un force peine l'épine Une bouffee d'épicefine Le tour est joué

Le totem des jours nouveaux Pointe vers l'horizon jaune Ma vie incinérée cendré Des espoirs consentis naviguent Sur le bateau des oubliés..

\section{DELIRIUM RÉALITÉ}

Par l'ouverture de sa porte

Il voit la lune pleine arrogante

Luire sur l'asphalte de l'avenue Mt-Royal

Il reflecchit sur le passage des êtres

Vers un autre état le ètre-insecte

L'évolution des carapaces

L'apparition des antennes

Six pattes pour se mouvoir

Dont quatre imaginaires et la cohésion de l'espèce

Tous dirigée vers un même but ultime,

La consécration du territoire

Les pistes tracées par les odeurs sacrées

Et la reconnaissance de la ruche-mêre.

Par la fermeture des valves

Il est engloutit par le soleil cuisant rayonnant

Et affirme dans la rue la prépondérance du jour

Il ferme les yeux pour découvrir le chemin des source

L'être-spécial, la force du faible

La substance du rien pleinement répandue:

La civilisation.

\section{CRACHE LA VIE!} par Denis Boucher

1 -- Perd le crayon retrouve la raison L'un s'achète l'autre est la preuve qu'on en a une

2 -- $\quad$ Flâner sur l'avenue des Libellules trou d'zéro mettre la croix dessus déguerpir en guise de rumeur risquer le voyage ami du pic-bois et des tordeuses aux p'tits fruits le restant de sa vie

3 -. On ne sait ni où ni quand ni comment il mourut

peut-être chez les Lohars nomades du Radjastan gardiens du feu ayant fait le voeu de n'habiter aucune maison

de ne jamais retourner dans la ville maudite dont ils ont été chassée

4 -. $\quad$ Le poète parle cimente les vieux mots invente le nouveaux et tire la langue 


\section{BOOKS RECEIVED}

The following are books received by Rampike. This list features books received which the editors consider praiseworthy and highly recommended. Alexis, André. Despair and Other Stories of Ottawa. Toronto: Coach House, 1994.

Anderson-Dargatz Gail. The Miss Hereford Stories. Vancouver: Douglas \& McIntyre, 1994. Antunes, Antonio, Lobo. Trans. Richard Zenith. Act of the Damned. Toronto: General, 1993. Barwin, Gary \& Stuart Ross. The Mud Game. Stratford: Mercury, 1995.

Beaulieu, Michel. Kaleidoscope: Perils of a Solemn Body. Toronto: Exile, 1988.

Benderson, Bruce. Pretending to Say No. New York: Penguin, 1990.

Bimey, Earle Last Makings. Toronto: McClelland \& Stewart, 1991.

bissett, bill. the influenza uv logik. Vancouver: Talonbooks, 1995.

Bök, Christian. Crystallography. Toronto: Coach House, 1994.

Borinsky, Alicia. Mean Woman. Nebraska: U of Nebraska P, 1993.

Borson, Roo. Night Walk Toronto: Oxford, 1994.

Bowering, George. George Bowering Selected: Poems 1961-1992. Toronto: M \& S, 1993.

Brault, Jacques. Fragile Moments. Toronto: Exile, 1985.

Brenner, Wayne. Alphabet Noir. Austin: Cafe Amageddon, 1993.

Brown, Robert Delford. Ikons of the First National Church of the Exquisite Panic, Inc. with a monograph by Robert C. Morgan at Fondazione Mudima. Milan, Italy, 1992.

Bukowsky, Charles. Screams from teh Balcony: Selected Letters 1960-1970. Ed. Seamus Cooney. Santa Rosa: Black Sparrow, 1993.

Catanoy, Nicholas. Notes On a Prison Wall. Vancouver: Ronsdale, 1994.

Charron, François. After 10,000 Years, Desire. Toronto: ECW, 1995.

Cooley, Dennis ed. Inscriptions: A Prairie Poetry Anthology. Winnipeg: Turnstone, 1992.

Crosbie, Lynn. Miss Pamela's Mercy. Toronto: Coach House, 1992.

Daigle, France. Real Life. Toronto: Anansi, 1995.

Damm, Kateri. My Heart is a Stray Bullet. Cape Croker: Kegedonce, 1993. David Rimmer: Films \& Tapes 1967-1993. Art Gallery of Ontario

Deisler, Guillermo \& Jorg Kowalski eds, wortBild: Visuells Poesie in der DDR. Leipzig: Mitteldeutscher Velag, Diaz, Luciano ed. Symbiosis. Ottawa: Girol, 1992.

Doleske. Homeshow Audio Tape (Small Potatoes \& Jake the Weasel), Centre of the Universe Productions, Box 152, Iron Bridge, Ontario, POR 1H0, Canada, 1994.

Dutton, Paul, Visionary Portraits. Stratford: Mercury, 1991.

Emily Carr Omnibus. Introd. Doris Shadbolt. Vancouver: Douglas \& McIntyre, 1993. Fagan, Cary. The Animal's Waltz. Toronto: Lester, 1994.

Farkas, Endre. Surviving Words. Montreal: The Muses' Company, 1994.

Fontana, Giovanni. Tarocco Meccanico. Napoli: Altri Termini, 1990.

Frutkin, Mark. Invading Tibet. Toronto: Random House, 1991.

Gagnon, Madeleine. Song for a Far Quebec. Trans. Howard Scott. Toronto: Coach House, 1994.

Galvin, E. Isabella Valancy Crawford: We Scarcely Knew Her. Toronto: Natural Heritage, 1994.

Glenn Gould: Descriptive Catalogue of the Glenn Gould Papers. Vol. 1-2. National Library of Canada, 1992.

Gerdes, Eckhard. Ring in a River. Evanston: Depth Charge, 1994.

Gilbert, Gerry. Year of the Rush. Toronto: Underwhich, 1994

Glover, Douglas ed.. The Journey Prize Anthology. Toronto: M \& S, 1993.

Glover, Douglas. The Life and Times of Captain N. Toronto: M \& S, 1992.

Greco,Heidi, Angela McIntyre, Isabella Mori.Siren Tattoo:A Poetry Triptych. Vancouver:Anvil,1994.

Grossetti, Ferdinando. Contra-Cantica. No. Tor Editore.

Hodgins, Jack ed. The Air Between Us: Winners of the 1994 Federation of B.C. Writers' Fest Writing Competition. Vancouver: Laughing Willow, 1994.

Hornick, Lita. Great Queens Who Loved Poetry. New York: Giomo Poetry Systems, 1993.

Hryciuk, Marshall. The Galloping. Toronto: Runaway Spoon, 1993.

Hufford, Charlie. The Toy Soldier's Heart. Oakland: Carter Press, 1992.

Hynes, Maureen. Rough Skin. Toronto: Wolsak \& Wynn, 1995.

Jailall, Peter. This Healing Place. Toronto: Natural Heritage, 1993.

Jirgens, Karl. A Measure of Time. Stratford: Mercury, 1995.

Jonas, George. The East Wind Blows West. Vancouver: Cacanadadada, 1993.

Kalynets, Ihor. Crowning the Scarecrow. Toronto: Exile, 1990.

Kroker, Arthur. The Possessed Individual. Montreal: New World Perspectives, 1992.

Laferrière, Dany. Dining with the Dictator. Trans. David Homel. Toronto: Coach House, 1994.

Laferrière, Dany. Why Must a Black Writer Write About Sex? Trans. David Homel. Toronto: Coach House, 1994.

Lusk, Dorothy Trujillo. Redactive. Vancouver: Talon, 1990.

Maillard, Keith. Dementia Americana. Vancouver: Ronsdale, 1994.

McCormack, Pete. Shelby. Vancouver: Douglas \& McIntyre, 1994.

McFadden, David W. There'll Be Another. Vancouver: Talonbooks, 1995.

McGrath, Donald. At First Light. Toronto: Wolsak \& Wynn, 1995.

Miki, Roy ed. Tracing the Paths. Vancouver: Talon, 1988.

Moritz, A.F. \& L. Zeller. Phantoms in the Ark: A Collage Poem. Vancouver: Cacanadada, 1994. Moure, Erin.The Green Word. Toronto: Oxford, 1994.

Nichol, b p. Truth. Stratford: Mercury, 1993.

Norris, Ken ed. Vehicule Days. Montreal: Nuage, 1993.

O'Toole, Lawrence. Heart's Longing. Vancouver: Douglas \& McIntyre, 1994.

Olbrich, Jurgen. Collective Copy. Kassel, Germany, 1994.

Parry, Mitch. Vacant Rooms Vancouver: Anvil, 1994.

Pennac, Daniel. Better Than Life. Toronto: Coach House, 1994.

Proulx, Monique. Invisible Man at the Window. Vaoncouver: Douglas \& McIntrye, 1993.

Purdy, Richard. The Tearing of Angels. Ottawa: National Library of Canada, 1994.

Reid, Gayla. To be There With You. Vancouver: Douglas \& McIntyre, 1994.

Rimmer, David. Films \& Tapes 1967-1993. Toronto: Art Gallery of Ontario, 1993.

Sabiston, Elizabeth Jean. The Prison of Womanhood: Four Provincial Heroines in Nineteenth Century. New York: St. Martin's Press, 1987.

Slavicek, Milivoj. Silent Doors: Selected Poems. Toronto: Exile, 1988.

Smith, Steven Ross. Reading: My Father's Book. Toronto: Wolsak \& Wynn, 1995.

Soljan, Antun. The Stone Thrower \& Other Poems. Toronto: Exile, 1990.

Stephens, Ian, Diary of a Trademark Montreal: The Muses' Company, 1994.

Tostevin, Lola, Lemire. Cartouches. Vancouver: Talonbooks, 1995.

Troendle, Yves. Nothing Personal. Toronto: Nietzsche's Brolly, 1994.

Vogel, Betty. Pilgrimage. Vancouver: Blueflower, 1993.

Wayman, Tom. The Astonishing Weight of the Dead. Vancouver: Polestar, 1994.

Whitehead, Gary. I Can Fix Anything. Vancouver: Arsenal, 1994.

Winter, Michael. Creaking in their Skins. Kingston: Quarry, 1994.

Yevtushenko, Yevgeny. Don't Die Before You're Dead. Toronto: Key Porter, 1995.

Zend, Robert. Daymares. Vancouver: Cacanadadada, 1991.

Zend, Robert. Nicolette. Vancouver: Cacanadadada, 1993. 